\title{
An Account of the Birth and Growth of Caddo Archeology, as Seen by Review of 50 Caddo Conferences, 1946-2008
}

Hester A. Davis

Unknown

E. Mott Davis

Follow this and additional works at: https://scholarworks.sfasu.edu/ita

Part of the American Material Culture Commons, Archaeological Anthropology Commons, Environmental Studies Commons, Other American Studies Commons, Other Arts and Humanities Commons, Other History of Art, Architecture, and Archaeology Commons, and the United States History Commons

Tell us how this article helped you.

This Article is brought to you for free and open access by the Center for Regional Heritage Research at SFA ScholarWorks. It has been accepted for inclusion in Index of Texas Archaeology: Open Access Gray Literature from the Lone Star State by an authorized editor of SFA ScholarWorks. For more information, please contact cdsscholarworks@sfasu.edu. 
An Account of the Birth and Growth of Caddo Archeology, as Seen by Review of 50 Caddo Conferences, 1946-2008

\section{Creative Commons License}

\section{(c) (1) (8)}

This work is licensed under a Creative Commons Attribution-NonCommercial 4.0 International License 


\title{
An Account of the Birth and Growth of Caddo Archeology, as Seen by Review of 50 Caddo Conferences, 1946-2008
}

\author{
Hester A. Davis and E. Mott Davis
}

PREFACE

\section{Hester A. Davis}

Any $50^{\text {th }}$ anniversary should be noticed as a milestone of some sort, whether of a person or a thing. In this case, any of you who can subtract will recognize that from 1946, when the first Caddo Conference occurred, to 2008 is more than 50 years. This is because between 1946 and 1965, there were only eight meetings, and we ran out of things to talk about (or people to agree to host the meetings) and did not meet in 1969. After the $12^{\text {th }}$ meeting in 1970, we have managed to have a meeting every year, and we have maintained a pattern of meeting in a different state of the four encompassing our research area, or at least a different host institution (see Appendix I).

We have maintained flexibility by not organizing: no constitution/by-laws, no officers, no members, and no $501 \mathrm{c}(3)$ status. This is not uncommon amongst regional archeological conferences, although several have felt the need for more structure as their attendance and publications grew.

In a weakened moment of nostalgia, I agreed to write this history of the Caddo conference because in 1982 I had agreed to help my brother, Mott, write a history of the first 25 meetings of the conference. Both Mott and I accumulated as much information - programs, agendas, photographs, tapes of the discussions - as we could at the time, and Mott actually drafted about 20 pages. But the effort came to naught at the time because of other obligations on both our parts.

At the time of the $40^{\text {th }}$ conference in Norman, Oklahoma, Bob Brooks and Lois Albert of the Oklahoma Archeological Survey began to draw together historical information on the Conference and I sent them some of my accumulation. As we neared the $50^{\text {th }}$ meeting, I inquired about the status of their files, and Bob brought me a large carton of files, slides, color prints, and tapes (some, unfortunately, old enough that the machine to play them on no longer exists). So now I have an even bigger box from which I am extracting the story of the birth and growth of the Conference-with a dab on the birth and growth of Caddo archeology as well. Their histories are, of course, inextricably woven together.

I agreed to this plan before the $50^{\text {th }}$ Conference in Natchitoches in March 2008, but said I would not start research or writing until after the meeting, so that I could pick people's minds as much as possible about their memories of the conferences. I was overly optimistic, and have managed to record only two stories. Fortunately, Dayna Lee (at Northwestern State University of Louisiana) did get several people to remember their first conference and those accounts can be found in the wonderful 50 th Caddo Conference: A Retrospective that Dayna saw to publication in time for the 50th meeting.

The grandfather of all conference histories (so far) is Dick Woodbury's (1993) on the Pecos Conference, written for the occasion of its 60th anniversary in 1987. (The Pecos Conference is also the grandfather of regional conferences, having been founded in 1927, and sometimes has had as many as 700 in attendance [Brian Kenny, 
personal communication, 2008]; and it, too, does not have memberships, officers, or other formalities.) I will spare you the detail that Dick was able to record (it took some 497 pages to tell that whole story), mostly because of a short time table to get this done. For example, some one else needs to do some biographical work on the careers of our first movers and shakers, and to speak at length to the Caddo themselves about their participation in the conference. Their interest in what comes from our research (see summary of the $27^{\text {th }}$ meeting in 1985), and their participation in the conferences, makes it very special—ours is the only regional conference dealing with a single Native American group. Since 1985, when we met at the University of Oklahoma, we are usually invited to Binger to visit the Caddo Cultural Center where a meal is prepared for us. Before we eat, however, we have learned that the Turkey Dance must begin and end before dark and that at the appropriate place in the presentation of the songs, we are invited by the women to dance with them; more dancing, singing, and drumming goes on after supper (Figure 1). Since the creation of the Caddo Cultural Preservation Office, a Caddo dance group has formed and has entertained at several of the conferences no matter where they are held.

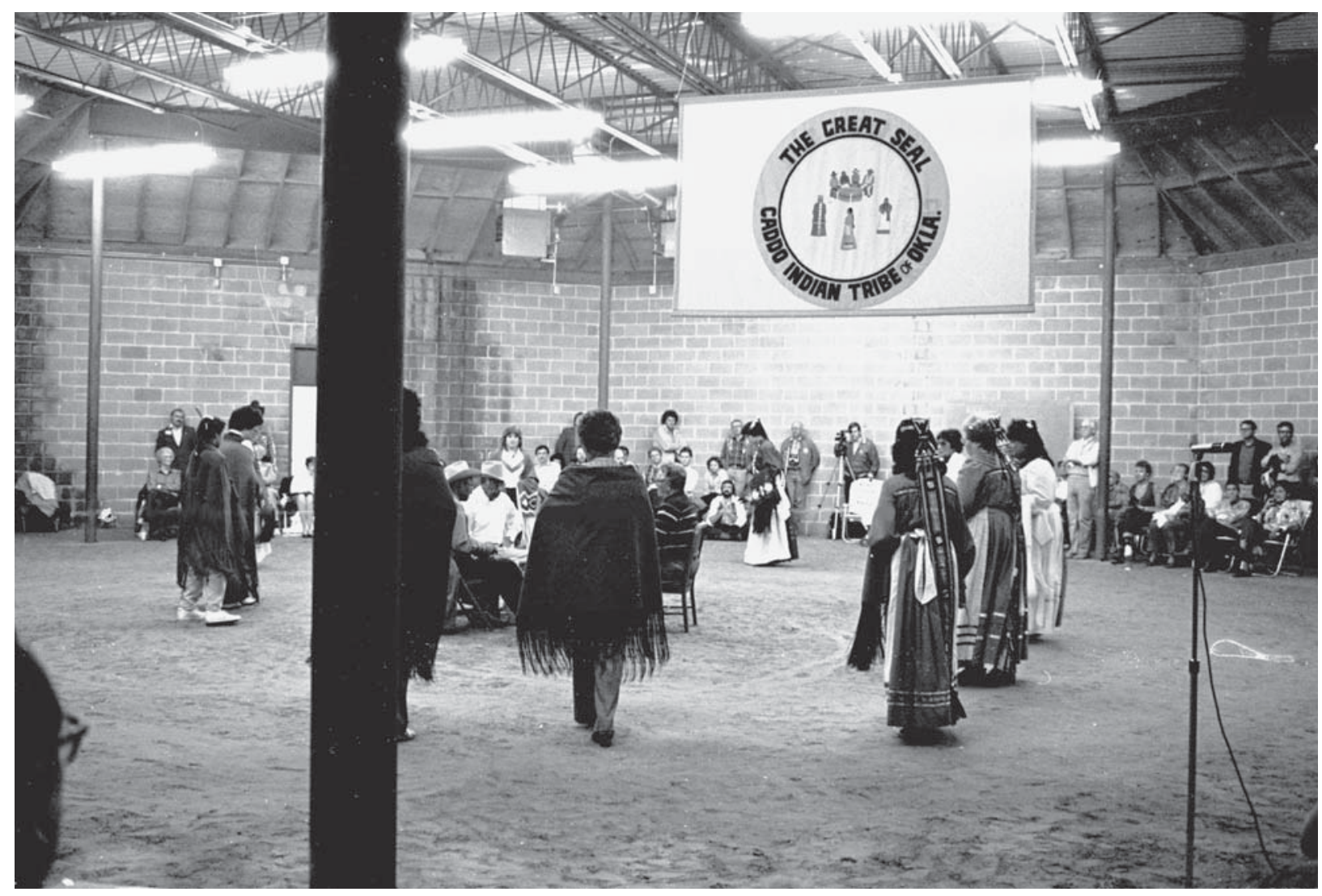

Figure 1. Caddo dancers, entertaining the archeologists at the Caddo Cultural Center in Binger, Oklahoma, Twenty-seventh Caddo Conference.

A look at the conference programs will give a sense of the "birth and growth" of Caddo archeology, and it can be seen that Caddo archeology reflects changes recognized in the technical, theoretical, and scientific approach to archeology as a whole in this country. The first emphasis at the early conferences was ceramic typology and the relationship between the Caddoan archeological area as it was then defined, and Mesoamerica. After the publication of the George C. Davis site report in 1949 (Newell and Krieger 1949), archeologists working in the Lower Mississippi Valley began attending the Conference regularly, looking for contact and relations between the cultures in both areas. Discussions broadened from chronology, typology, and the manufacture of ceramics to sites themselves, to burial patterns, settlement patterns, and the social, religious, and political organization of 
communities. It is all there in the informal and formal parts of the conferences. I have come to realize, however, that, as far as people's memories of the meetings are concerned, what may be best remembered are the informal gatherings and the opportunity for "networking." While the roundtable discussions of a small number of people that constituted the first few conferences was almost solely confined to ceramic typology, as the attendance grew these small discussions became panels and then symposia and formal papers, but the Caddo Conference has almost always included at least a half day of short reports on current research. A few show and tell sessions still appear, when samples of ceramics and/or lithics are brought to the Conference for comparison.

I have incorporated below what Mott wrote 25 years ago on the first 25 conferences, and adding to it other information where I was able. In keeping with the tone of the conferences, I have tried to keep this story as informal as possible

\section{BACKGROUND}

\section{E. Mott Davis}

Up until the time of the first conference in 1946, North American archeologists in general thought of the adjacent parts of Arkansas, Louisiana, Oklahoma, and Texas as an area of relatively uniform late prehistoric "Caddo culture," a complex of traits including well-made pottery and large mounds, which was, in effect, the westernmost manifestation of the Mississippian pattern (Martin et al. 1947:421-424). What was known of the area and the artifacts came largely from the expeditions of Clarence B. Moore, on the Ouachita River in Louisiana and Arkansas in 1908-1909, and on the Red River in 1911-1912 (Weinstein et al. 2003), and of Mark R. Harrington in southwest Arkansas in 1920 (Harrington 1920). Starting in the mid-1930s, the Works Progress Administration sponsored several excavations at large mound/cemetery sites, the best known of which were excavations at the Hatchel and George C. Davis sites in northeast Texas, probably because the results were published (Krieger 1946:213; Newell and Krieger 1949). There were also a number of amateur archeologists working in this area, sometimes under the guidance of professionals, and publishing their findings in the Bulletin of the Texas Archaeological and Paleontological Society and the Bulletin of the Texas Archeological Society (Webb 1940, 1941, 1945; Hodges and Hodges 1943; Hodges 1957; Lemley 1936; Dickinson 1936, 1941; Dickinson and Lemley 1939). Clarence B. Webb, in particular, began his excavations at the Belcher site in northwest Louisiana in 1935, published the first descriptions of Caddo house types in 1940 and pottery types from this research in 1941. After World War II, he continued to work at the Belcher site (1952-1954), culminating in his final report in 1959, published by the Society for American Archaeology as Memoirs 16 (Webb 1959).

The organization of data from the Caddo area into a coherent ceramic classificatory system began with Webb's (1941) published paper. His type names and descriptions followed a format designed for Southeastern pottery by James B. Griffin and James A Ford, and adopted by the First Southeastern Archaeological Conference in 1938 (Ford and Griffin 1937, 1938). Webb acknowledged Griffin's and Ford's assistance in classifying his material (Griffin and Ford had modeled their system on nomenclature for the Lower Mississippi Valley, with modifications, after that in use in the Southwest).

When we started work on this history in 1982, we appealed to Webb for information and Webb sent original copies of letters from Perry Newell and Alex Krieger, starting in 1941 (when both were working at the University of Texas). Newell's three letters (two in the fall of 1941, and one in early January 1942) deal with the possibility of a get together in Shreveport to look at each other's pottery. (Newell went off to war after the meeting in 1942 and died of lung cancer soon after his return home in 1946.) There are three letters from Krieger to Webb (1942, 1943, and 1945) all dealing with pottery typology. By the time of the 1942 meeting in Webb's home, Krieger 
had begun a major study of all the Caddo materials in the archeological collections at the University of Texas in Austin and all the letters deal with details of his ceramic typology, and in the last letter, with the conference he was planning for the fall of 1946. (Presumably Webb's side of this correspondence is in his archives at the Louisiana State Museum in Shreveport.)

Although the numbering of Caddo Conferences "officially" begins in 1946, in point of fact, there were several small gatherings at Clarence's house in Shreveport prior to that. In Webb's words:

The concept of interrelations over the four-state area was beginning to ferment. Eventually, in January 1942, Krieger and Newell from Texas, Baerreis and Cobb from Oklahoma, and Beecher and I from Louisiana spent a weekend together at my home studying archeological data. We confirmed or established ceramic types, compared materials from the several states, and laid the groundwork for areal cooperation that culminated, in 1946... in the First Caddo Conference at the University of Oklahoma (Webb 1978:33).

\section{PART I: THE FIRST 25 CONFERENCES, 1946 TO 1983}

\section{E. Mott Davis (edited by Hester A. Davis)}

\section{6: "Symposium On The Caddoan Archaeological Area"}

This first conference was held in Norman, Oklahoma, on the campus of the University of Oklahoma, September 12-14, 1946. There were 41 people in attendance including one Caddo Indian-Vynola Beaver Newkumet, wife of archeologist Phil Newkumet (Figure 2). The conference was largely instigated by Alex Krieger of the University of Texas, and was hosted by Dr. J. Willis Stovall of the University of Oklahoma. Kenneth Orr (University of Chicago) was listed as Chairman Pro tem, and Alex Krieger as Co-Chairman Pro tem.

In a letter to Webb in April 1946, Krieger describes his plans for this conference:

We had a pretty good preliminary meeting, Griffin, Orr, Stovall (of Norman), Kelley [J. Charles], [Glen] Evans, Tom Campbell, and I, having a look at the stuff we have here (at the University of Texas, Austin) and then having a bull session, for these other fellows had to catch up on what you and I have been talking about these years.

I said "preliminary" above because Orr and I began making plans last fall for the first "Caddo Area Conference," to be held in Norman in September... We plan to issue invitations to about 15 or 20 men who know their stuff and keep the discussions intimate [see below where "about 60" invitations were sent out].

This first "official" gathering stands, it strikes me, as one of the most "pre-planned" of all the 50 Caddo Conferences, with what could be called a syllabus, rather than an agenda, created by Krieger and Orr and sent to about 60 "specialists," not just from the "Caddoan Area," but from all adjacent states and archeological areas as well, including Mexico. It was emphasized that there were to be no formal papers.

The purposes (plural) were ambitious (Krieger 1947:198; wording in this published summary report is slightly different from the 5 page mimeographed document, mentioned above and quoted below, sent with the invitation to attend):

1) To assemble detailed data relative to the definition of culture units throughout the Caddoan archaeological area.

2) To reach agreement on the content, identity, and interrelationships of culture units within the Caddoan area. 


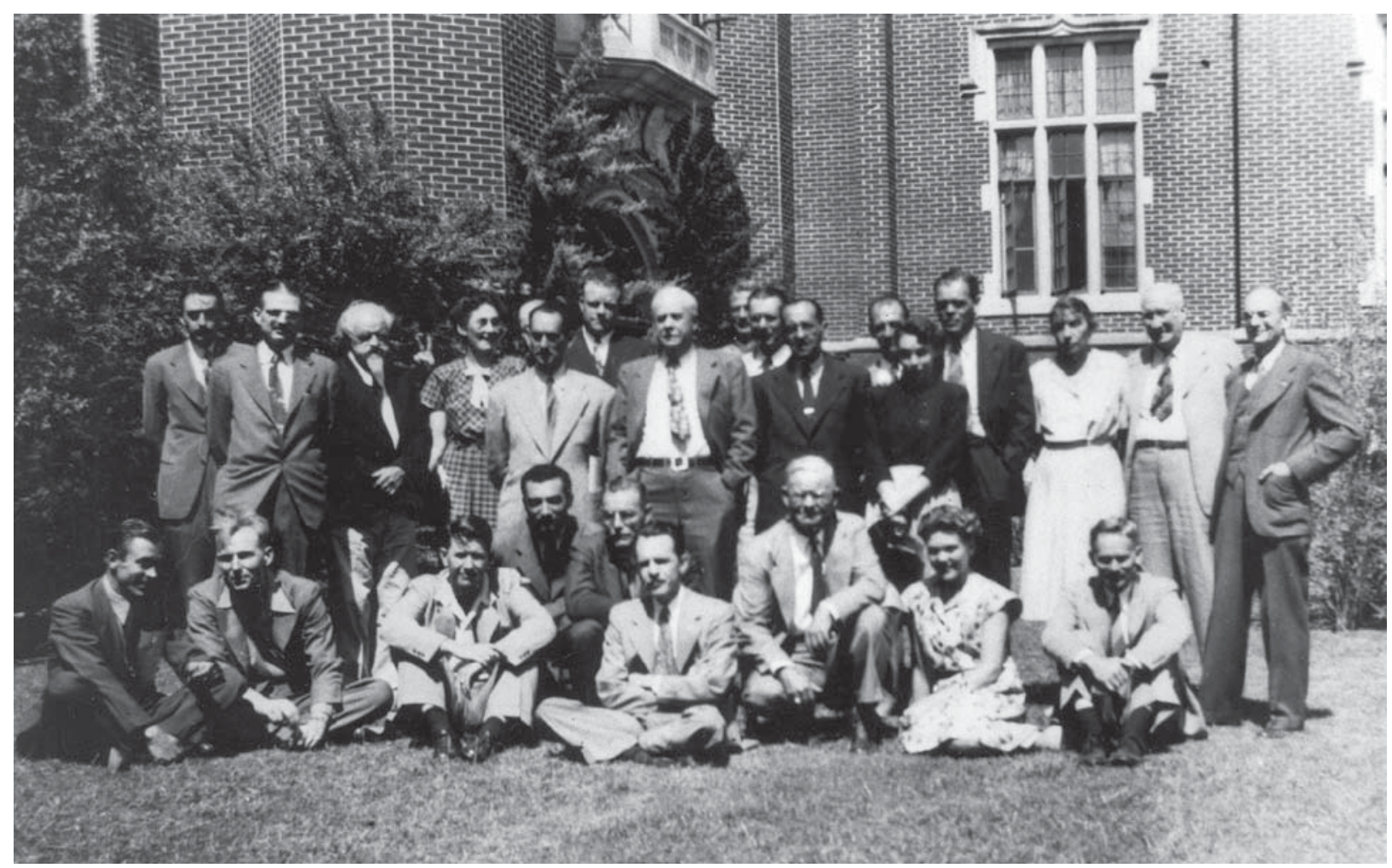

Figure 2. 1946 Symposium on the Caddoan Archaeological Area. Standing, left to right: unidentified, John C. McGregor, Jesse Wrench, Mrs. Henry Hamilton, unidentified (partial head), Wilfrido du Solier (or Carl Chapman?), unidentified, H. P. Mera (?), Alex D. Krieger, Henry Hamilton, Eduardo Noguera (or Carl Chapman?), Pete Miroir (?), Doris Morrisett Howard, Lynn E. Howard, Mrs. T. L. Hodges, T. L. Hodges (or John Henry Ray?), Thorne Deuel. Sitting and kneeling, left to right: Phillip Newkumet, David A. Baerreis, Kenneth G. Orr, Pedro Armillas, unidentified, Richard S. MacNeish, J. Willis Stovall, Mrs. Alex D. Krieger, and Georg Neumann. Identifications by Harry Trowbridge.

3) To integrate these units with those recognized in surrounding and related areas.

4) To discuss the broader implications of these correlations in relation to the Southeast, Southwest, Plains, and Mexico.

5) To determine the major unsolved problems in Caddoan area research.

In the published account, Krieger continues (1947:198-199): “To accomplish these purposes, invitations had been extended to two groups of archaeologists: those conducting work and research within the Caddoan area [which included amateurs with known large collections], and those who have published broader interpretations involving "Caddoan" archaeology. Those in active research within the area were asked to bring whatever materials, such as characteristic specimens, trait lists, house and burial data, photographs, maps, charts, etc., would enable them to show objectively the content of each cultural association with which they were working. In addition, it was suggested that they bring any odd or intrusive, possible trade, specimens so that others could identify them, and trade relations between the cultures also [could be] worked out. We aimed at achieving a maximum of discussion with the actual specimens on hand, and a minimum of formality" (Krieger 1947:198-199).

Krieger (1947:199) declared that the Symposium succeeded far beyond expectations. His American Antiquity account is nine pages of details on the discussions by day and by topic, which also indicates who commented 
on the topic at hand. The report provides for us, today, an excellent background upon which information on the growth in understanding of the distant past of the Caddo Nation is based.

The participants (see Figure 2) included nine non-professionals who had extensive familiarity with Caddoan materials. Eleven were non-Caddoan North American archeologists. The total number of persons, professional and nonprofessional, who were intimately familiar with Caddoan and closely related materials was about 10:

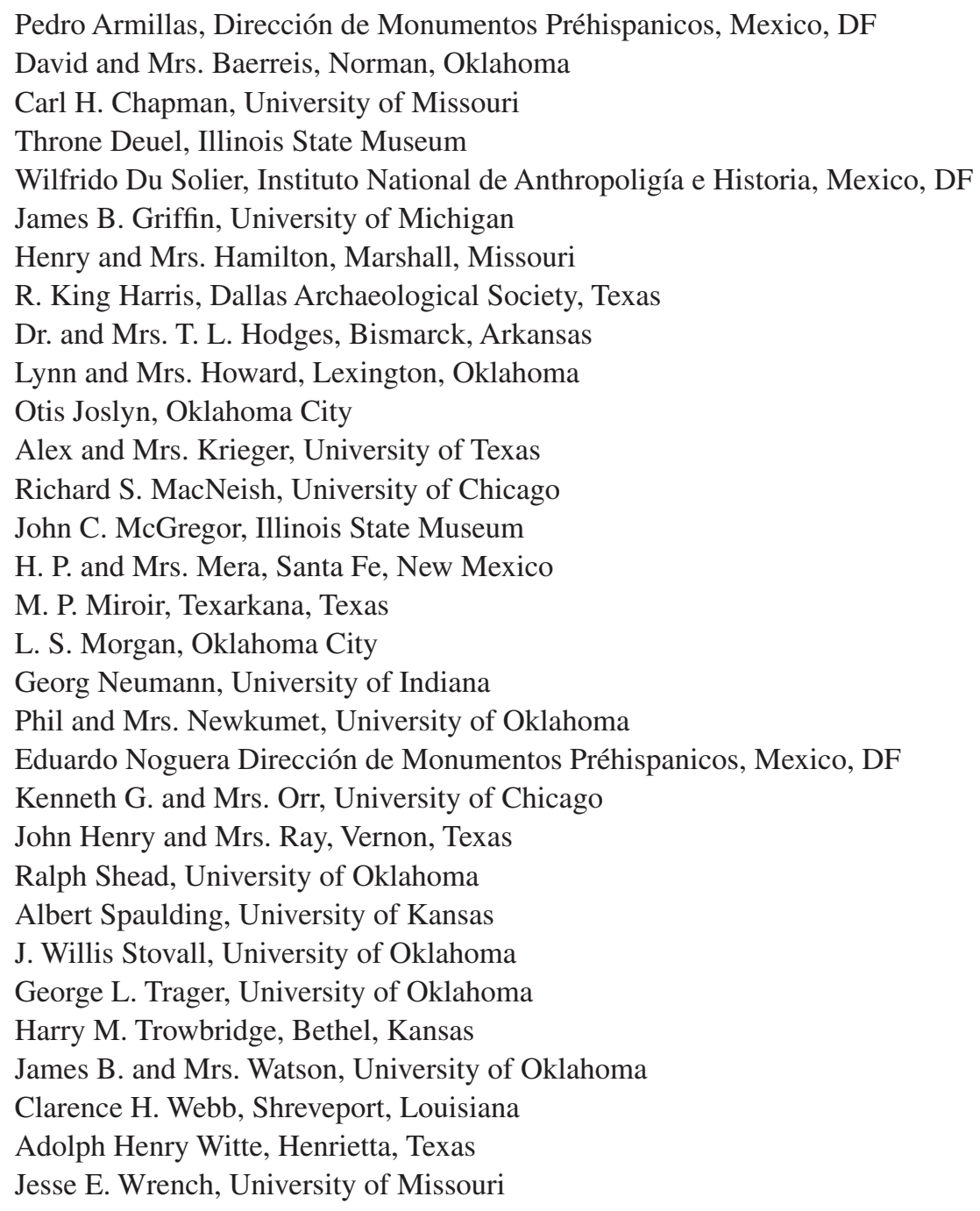

[The following summary of this conference was written by Mott in 1983.] The conferees agreed that the linguistic term "Caddoan" was not a felicitous one for an archeological area, but they were unable to come up with a better name (in his published account of the conference, Krieger usually put quotation marks around "Caddo," implying that it was not entirely acceptable either).

On the first two days, complexes were defined and discussed. In systematic fashion, the traits of the several Caddoan foci that Krieger had defined (see Krieger 1946), and several which had been defined by others, were laid forth. They were presented in three groups, those in historic times (Glendora and Mid-Ouachita), those from late prehistoric times (Frankston, Titus, Belcher, Bossier, and Texarkana), and those from earlier times (Haley, Gahagan, Alto, Sanders, Nelson, McCurtain, and Spiro). In each case, sites and features were described 
and specimens were brought forth for examination and comparison. There appears to have been no significant disagreement about the definitions of these complexes.

At the end of this part of the conference, three complexes closely related to Caddoan were presented: Fourche Maline, the ceramics of which were seen as ancestral to some Caddoan materials, and two southern Plains foci [perhaps Washita River and Grant?] bordering the Caddoan area on the west.

On the third day, there was an intensive examination of the possible relationships, cultural and chronological, between Caddoan complexes and others in North and Middle America. In this discussion, attributes were traced over wide areas in order to establish cultural and chronological ties. Krieger's trait correlations across north Texas, from the Southwest to the Caddoan area, and from the Lower Mississippi Valley (which were about to appear in his major monograph, Cultural Complexes and Chronology in Northern Texas [Krieger 1946]), provided some chronometric control. The comparisons suggested times and routes of influence between a number of areas: Caddoan and prehistoric Pawnee; Spiro and other Caddo; Spiro, Cahokia, and other Mississippians; and Caddoan, Southwestern, and Middle America.

Krieger felt that two and perhaps three ceramic traditions are to be seen in Caddoan ceramics: dark engraved ware in the early complexes is Mesoamerican in origin; incised and punctated pottery is related to Coles Creek and complexes farther east, probably ultimately deriving from Hopewell; and cooking vessel forms may be Woodland in origin. He saw ceramic influences from Middle America as being distinct from, and earlier than, ceremonial (i.e., Southern Cult) influences. "There is no longer much doubt in my mind," he quotes himself as saying, "that Spiro was the approximate place of entry of several Huastecan traits in the eastern United States, and that these were accretions to a flourishing culture rather than original stimuli" (Krieger 1947:205-206).

It can be seen that the conference reflected the principal concerns of American archeologists at that timeproblems of integration of data into frameworks of time and space relationships. The same concerns were being shown at other regional conferences, such as the Southwestern (Pecos) and Plains conferences, in that immediate post-war period. The only exception to this concern that Krieger reported in the Caddo conference was a remark by Orr, near the end of the final discussion, that "One thing especially needed is a detailed study of culture growth in the "Caddoan area.",

It was planned that this first conference would result in a major volume, edited by Krieger, in which the traits of each complex would be listed and illustrated. This plan never reached fruition, but the objective was attained eight years later with the publication of An Introductory Handbook of Texas Archeology (Suhm et al. 1954; hereafter referred to as the Texas Handbook), in which the East Texas section, completed by Krieger, summarized all of Caddoan archeology, both in and out of Texas (Suhm et al. 1954:144-227).

At the end of the conference, Orr was empowered to form a committee "to consider the permanency of the Symposium... and... to find a name to replace 'Caddoan' for archaeological purposes" (Krieger 1947:200). Either this committee did not function, or the symposium was judged to be impermanent, for nothing more was heard of the "Symposium" as such. As for the name, Phil Newkumet soon found the Caddo word habiukut, meaning "ancient times" (Krieger 1947:206, fn. 5), but it was never adopted. (The matter was again brought up briefly at the Fifth Caddo Conference in 1958 [Davis 1961b:89-90] and has not been discussed since.) (Mott's summary of this conference ends here.)

There was one other matter that may have been discussed during the conference, but perhaps only during whatever social hours there must have been, since it is not mentioned by Krieger in his summary. However, in 
Hester's files is an original letter, written in October 1946, from James Watson (Curator of Anthropology at the University of Oklahoma) to Lynn Howard then in Lexington, Oklahoma (for history's sake, the total content of the letter is in Appendix II). It must have been in Howard's files at the University of Arkansas Museum when he left in 1955, and probably is a "form" letter to several people. It indicates that after the conference, there was conversation (perhaps just between Stovall and Griffin) about the development of a "Caddoan Archaeological Ceramics Depository" at the University of Oklahoma. Surely the original idea for this came from Jimmy Griffin, who was at the time, in charge of the Ceramics Repository (for the eastern United States) at the University of Michigan. Don Wyckoff says that there was no such Caddoan Ceramic Depository when he went to work for Dr. Bell in the Museum in 1960 (personal communication, May 2008). Don says that Bob Bell had a type collection of sherds from all over the eastern and southeastern U.S., but not especially for the Caddo. Watson must not have gotten very many positive responses.

In one of Webb's letters to Mott in 1983, he wrote:

In 1947, between the First Caddo Conference and the...1950 meeting, Alex Krieger and Pedro Armillas spent two days at my home, looking at the Caddoan materials from NW Louisiana and still mulling over the possible Mexican/Mesoamerican connections. Mrs. Webb still chuckles at the memory of Pedro finally getting worn out with the talking and retiring to a lawn chair between my workshop and the street, where he almost precipitated two traffic wrecks because of drivers goggling at his flowing whiskers and beard.

\section{0, Second Caddo Conference, Shreveport, Louisiana, August 4-6}

This was more an informal discussion than a "conference" such as we now hold, much like those which must have occurred between 1942 and the 1946 gathering. Nevertheless, it was considered by Krieger to be especially useful. The discussions were held at the home of Clarence Webb (correspondence indicates that Mrs. Webb prepared some meals for these colleagues); there were only six people present: Alex Krieger (University of Texas); Clarence Webb (Shreveport, Louisiana); Bill Haag (Louisiana State University, working in the Lower Mississippi Valley); Lynn Howard (he had worked at Battle Mound with Krieger in southwest Arkansas); John Cotter (with the National Park Service at the time, working on sites on the Natchez Trace) ; and Bob Stephenson (head of the River Basin Survey office at the University of Texas) (Figure 3). Some sources call this the Conference on Pottery Typology, each man having brought sherds or pottery vessels for show and tell. Krieger reports (Suhm et al. 1954:160) that "Many Caddoan types were reviewed with specimens and photographs, most of those previously established by Webb and Krieger being accepted with little modification. Several new ones were defined..." Some of these new ones were published for the first time in Suhm et al. (1954).

\section{2, Third Caddo Conference, called "Caddoan Area Workshop Session," Norman, Oklahoma, April 22-23}

Ten people were in attendance (I count only nine mentioned in Bell's report: Bell, Lehmer, Howard, Webb, Jelks, Baerreis, Schmitt, Haag, and Griffin). The meeting was reported on by Bob Bell (American Antiquity 1952:95-96), in the "Notes and News, Plains" section, perhaps because the editors of this journal thought of Bell and Krieger as from institutions (Oklahoma and Texas) identified with the Plains. Mott observed that in Bell's summary, Caddo and Caddoan are not set out with quotation marks, signaling that the Caddoan area was at last one of the recognized archeological areas in North America.

Field work was reported on for the first time. Bell was working on pre-Caddoan and later sites in the Tenkiller Reservoir on the Illinois River in northeastern Oklahoma, and Donald Lehmer reported on work in Late 


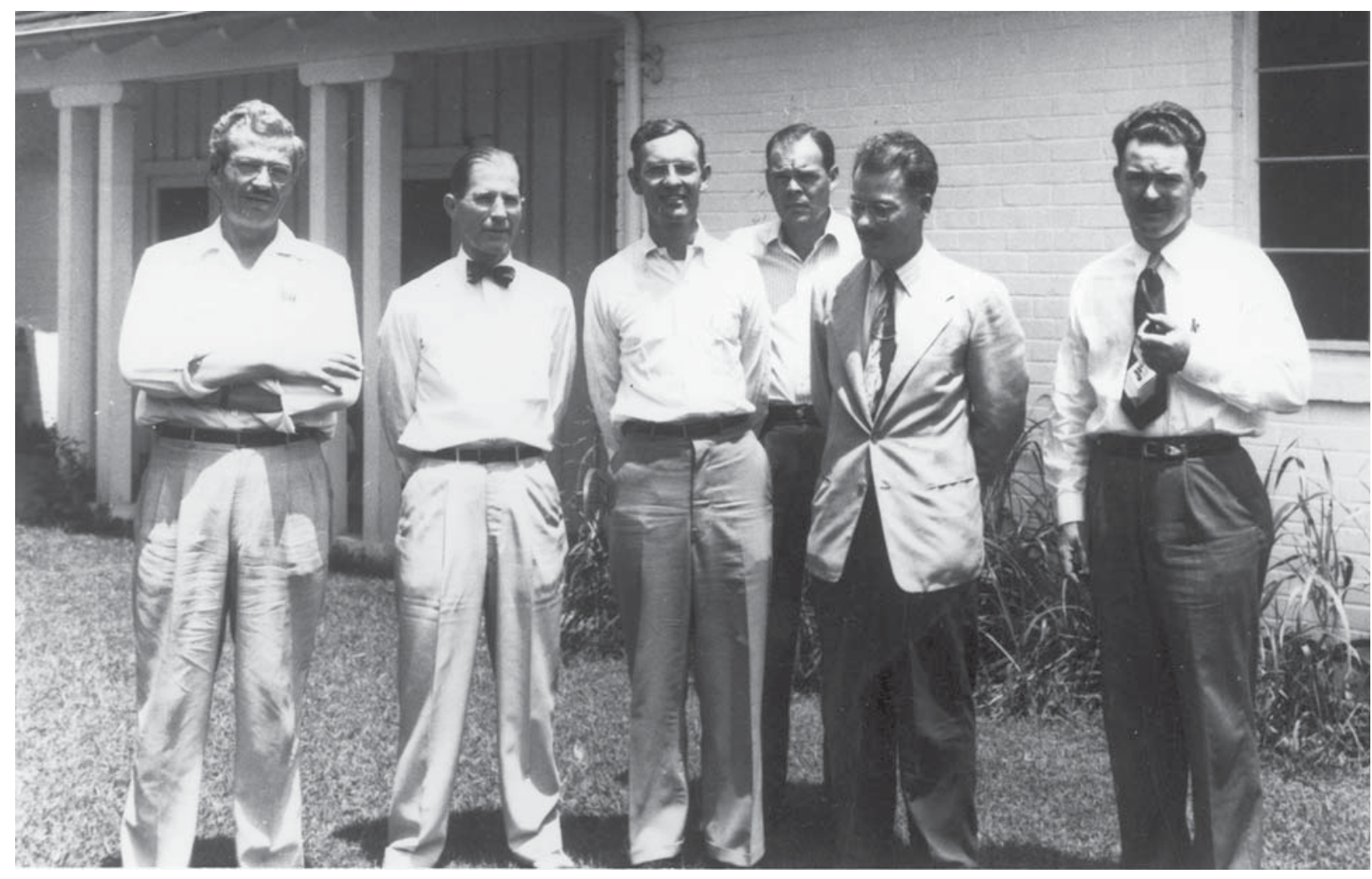

Figure 3. Attendees at the Second Caddo Conference, Clarence Webb's house, left to right: Alex Krieger, Clarence Webb, Bill Haag, Lynn Howard, John Cotter, and Bob Stevenson.

Caddo sites in the same area. Lynn Howard discussed his and Krieger's 1948 work at the Battle Mound site in southwest Arkansas near the Red River. Webb reported on the work of Robert Fulton at the Bellevue Mound in northwestern Louisiana, where pre-Caddo Marksville-like materials were being found. Ed Jelks, who was about to begin excavations at the Texarkana Reservoir, told of Caddoan sherds that were being found far to the southwest of the Caddo Area, at the Belton Reservoir in Central Texas. David Baerreis (University of Wisconsin) described material from his pre-World War II work at the Smith shelters in northeastern Oklahoma, in particular the plain shell-tempered ware tentatively named Woodward Plain, that related his sites to Late Caddo sites farther south. Karl Schmitt (University of Oklahoma) spoke of his ethnographic work on recent Caddo burial customs, and reported on the Washita River focus, a southern Plains complex just west of the Caddo Area. Bill Haag (Louisiana State University) described the Poverty Point horizon that was then being defined by the work of Webb, Ford, and Phillips.

The rest of this meeting was concerned, once again, with pottery types in the Caddo area. The group finally agreed that currently recognized types should be written (and presumably distributed) in the standard form used in and published by the Southeastern Archaeological Conference (Ford and Griffin 1938). Jimmy Griffin attended these meetings as an expert on Southeastern pottery, "and often he, Krieger, and Ford led spirited discussions of cultural and temporal manifestations" (Webb1978:33). One would assume that he would have asked for sample sherds of the types being named for the Ceramic Repository at the University of Michigan.

The impression gained from this account is that Caddoan archeologists were still preoccupied with pottery typology, but that little new was accomplished at this 1952 "workshop." It is also noteworthy that although Bell used the phrase "members of the conference," implying a group with some coherence and continuity, five 
years were to pass before there was another meeting of Caddoan archeologists. It seems as though workers in the Caddoan area felt a need for communication on the complex problems that were beginning to emerge, but not enough research was going on to stimulate regular yearly conferences.

Krieger, writing the introduction to the Caddo section of the Texas Handbook in 1954, spoke of the 1950 Shreveport session as significant in defining and regularizing pottery types, but he did not mention the 1952 Norman workshop. Further discussion of major classificatory and chronological problems would have to await more research.

\section{Four Years Between Conferences, 1953-1957}

All was not silent during this gap between conferences, and field work continued at a modest rate. Bell held summer field schools at a number of Caddo sites in eastern and southeastern Oklahoma. The Oklahoma Archeological Salvage Project was established in 1956 to work at proposed reservoir sites. Webb completed his excavations at the Belcher Mound and prepared the results for publication (Webb 1959). Jelks finished his work at the Texarkana Reservoir (Lake Wright Patman), but was forced to close the River Basin Survey office in Austin in 1954 because of federal budget-trimming. Reopening it in 1956, he carried out a season of excavations at the McGee Bend Reservoir ((Lake Sam Rayburn) in East Texas. Meanwhile, in 1956, Krieger left the University of Texas (UT) and moved to the University of California at Riverside, terminating his Caddo research. His place at UT was taken by E. Mott Davis, who in early 1957 began work in the Ferrell's Bridge Reservoir (Lake O' the Pines) in northeastern Texas. Lynn Howard left the University of Arkansas in 1955, without finishing his report on the work at Battle Mound. Howard's place was taken in 1957 by Charles R. McGimsey III, but work did not begin in the Caddo area of Arkansas by professional archeologists until after 1960. Also in 1957, Mrs. T. L. Hodges published on research in the central Ouachita River valley in Arkansas in the Bulletin of the Texas Archeological Society.

Jelks, analyzing his material from McGee Bend (which is at the southern edge of the Caddoan area), found that his Caddo-like specimens did not fit well in the existing Caddoan taxonomic framework. In the field at Ferrell's Bridge, Davis, too, was grappling with an anomaly, the Whelan Mound site. Jelks proposed to Webb and Davis that it was time for another Caddo Conference, and Webb arranged for it to take place in Shreveport.

\section{7, Fourth Caddo Conference, Shreveport, Louisiana, April 13-14}

The Louisiana State Exhibit Museum, where the Poverty Point diorama was then under construction, was the scene of this meeting. There were 13 people in attendance, which included most of those then active in Caddo archeology. Webb served as Moderator; it was he who had drawn up an "agenda" (i.e., suggested topics for discussion).

Participants were as follows:

Michael Beckman, Shreveport, Louisiana

Robert E. Bell, University of Oklahoma

E. Mott Davis, University of Texas

W. A. Davis, Jasper, Texas

Robert L. Fulton, Shreveport, Louisiana

Pete Gregory, Louisiana State University

William G. Haag, Louisiana State University

Edward B. Jelks, National Park Service, Austin, Texas 
LeRoy Johnson, Jr., National Park Service, Austin, Texas

Robert S. Neitzel, Marksville State Park, Louisiana

James B. Shaeffer, University of Oklahoma

Clarence H. Webb, Shreveport, Louisiana

Fred Hadleigh West, Louisiana State University

Those contributing later comments to the draft proceedings:

David A. Baerreis, University of Wisconsin

W. W. Crook, Jr., Dallas, Texas

R. King Harris, Dallas, Texas

Alex D. Krieger, Riverside Municipal Museum, Riverside, California

Philip Phillips, Harvard University

Robert L. Stephenson, Smithsonian Institution

As the first order of business (although, of course, there was no formal business meeting), Ed Jelks, now Director of the River Basin Surveys in Texas, suggested the conference "be made a regular affair." As a consequence, Mott Davis was "voted" secretary. He took notes, transcribed them into grammatical English, sent the result to all participants for corrections and additions, made the suggested changes, and then sent the results to six archeologists who had not attended the meeting, but who worked in the area on the problems discussed, for their comments and contribution. The whole was published in the 1960 Bulletin of the Texas Archeological Society (M. Davis 1961a:1-33).

The topics covered are outlined in the Table of Contents in Davis (1961a): (1) a discussion of the taxonomic framework for Caddoan culture (Gibson Aspect, Fulton Aspect, and Pre-Gibson); (2) ceramic typology, particularly surface treatment but also distribution of ceramic attributes among the named types; (3) new information on "marginal cultures"-East Texas (particularly the McGee Bend reservoir area); (4) Wylie Focus (Jelks: "sort of a buffer between the Caddo area and the Plains."); (5) Central Texas Caddoan material ("between the Brazos and Trinity rivers, and between latitudes of Waco and Austin..."; Alto, Frankston, Sanders foci); (6) Oklahoma quartzite industry (Bob Bell and Jim Shaeffer brought samples of chips, cores, and tools from sites principally in central Oklahoma. The few tools seemed to be Archaic; Caddo sites have similar tools but not of this quartzite material); (7) peripheral material in Arkansas ("Were there Caddo settlements along the lower Arkansas River?...Are these Caddo sites with some Mississippian and Quapaw, or are they...Quapaw with Caddo influence?"); and (8) the Sanson site ("on the south end of Catahoula Lake in Rapides Parish, Louisiana." A large site with mounds and "vast midden accumulations."). Webb summarized the information from this site: "The Sanson site represents occupation from late Archaic through Marksville-Troyville and Coles Creek to a final, and apparently major, occupation by a mound-building people whose culture represents an admixture and amalgamation of Fulton Aspect Caddoan and Plaquemine traits...In relation to the Caddoan area, Sanson could be considered as a fringe culture which has Caddo affinities" (Davis 1961a:30).

A general discussion followed dealing with (1) trade (particularly in relation to Poverty Point and Hopewell), (2) the "Haag-Webb controversy on where the Poverty Point people got the idea of building those earth structures," and (3) burial types.

Finally, Fred Hadleigh West (Louisiana State University), for the first time, brought up the topic of historic sites. Mott's transcript indicates that few historic sites had been excavated and little was known from surface collections. Sites mentioned are: Spanish mission sites around Nacogdoches and Natchitoches, Hunt and Clements in East Texas, Womack, and Spanish Fort (Jelks commented that this site is "on both sides of the Red 
River in Oklahoma and Texas, is a major historic site; this is a Taovayas site [Wichita Confederacy]"). Another is Stansbury on the Brazos River above Waco, probably Tawakoni ("Wichita Confederacy") (Davis 1961a:31). There was extended discussion (not recorded) of trade goods, and West sent in after the conference a concluding statement on "what are presently taken to be contact sites in northwestern, central, and southeastern Louisiana." Mentioned are the Bayou Goula and Los Adaes sites, and the ubiquitous nature of feather-edged ceramics (Davis 1961a:31-33).

With this meeting, the Caddo Conference became a recognized continuing entity, although several years would pass before the meetings were planned annually.

\section{8, Fifth Caddo Conference, Norman, Oklahoma, April 30-May 1}

This conference was held the day before the beginning of the $23^{\text {rd }}$ annual meeting of the Society for American Archaeology (SAA, which was held jointly that year with the Central States Anthropological Society). Bob Bell, as program chair for the SAA meeting, asked Mott to arrange a symposium (which turned out to be the plenary session), providing a short introduction to the status of archeology in the Caddoan area, and then concentrating invited papers on "Relationships between the Caddoan area and Neighboring areas" (Davis 1961d).

There were 19 in attendance in the day-long Fifth Caddo Conference and the proceedings of those discussions, again edited by Mott Davis, and the papers given at the SAA symposium, were both published in 1961 in Volume 31 (for 1960) of the Bulletin of the Texas Archeological Society. The participants were:

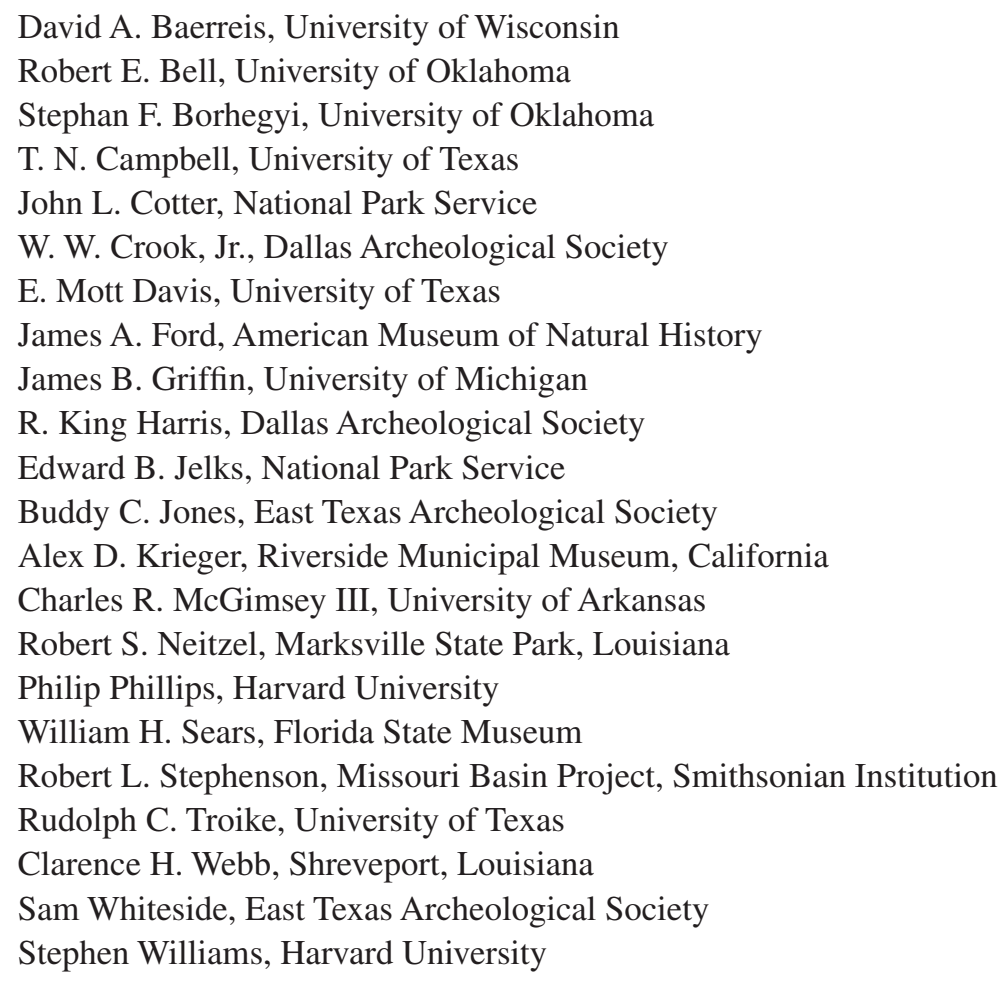

\section{Accomplishments of the Fifth Caddo Conference}

The following summary is quoted from the published proceedings (Davis 1961b:78). The specific topics discussed and the titles of the papers in the plenary session (Davis 1961c) are listed in Appendix III: 
The conference participants included a number of workers whose interests are primarily in the problems of the Lower Mississippi Valley. As a result, the discussion kept moving into the questions of relationships between the Mississippi Valley and the Caddoan area, and the correlation of their chronologies. In general, the Mississippi Valley specialists felt that the earliest Caddoan materials are approximately contemporary with the end of Coles Creek times in the Valley, whereas the Caddoan specialists felt that Caddoan materials appear at the beginning of Coles Creek times, or perhaps earlier. This argument has been going on a long time, and it was not resolved at this conference. Possibly a major result of the conference was that the two schools of thought had an opportunity to find out, after some years, what the other side was thinking.

The other major accomplishment of the conference was an examination of the Archaic antecedents of the Caddoan complexes in the area. A fundamental continuity of culture from the Archaic into the Caddoan cultures, reflected in the carrying over of many stone artifact traits, was emphasized by many of the discussants. The matter of possible transitional complexes—post-Archaic, pre-Caddoan ceramic cultures—was also reviewed in some detail.

\section{2, Sixth Caddo Conference, February 2-3, Austin, Texas}

Again, four years elapsed between conferences, even though there was considerable research going on. In Arkansas, an archeological program was being developed by the University of Arkansas Museum in Fayetteville, under the leadership of Bob McGimsey, with assistance from Hester Davis. In the mid-1950s, Jelks had done an initial survey of Millwood Reservoir on the Little River, but it was not until 1961 that testing was done by Jim Scholtz, a graduate student at the University of Arkansas and research assistant at the Museum. By the early 1960s, Jelks was with the Texas Archeological Salvage Project (ancestor of the Texas Archeological Research Laboratory) and was concentrating on protohistoric and historic Caddo sites, leading to the eventual formulation of the Norteño focus. In East Texas the archeological story was being extended back in time with investigations of pre-ceramic sites by Lathel F. Duffield, Mott Davis, and LeRoy Johnson, Jr. Meanwhile, salvage work continued as before in Oklahoma, Don Wyckoff now adding his energies to that of Bob Bell, and Webb maintained his activities in northwestern Louisiana.

By 1961, pressure was growing for another Caddo conference. It had been suggested at the Norman meeting that the next conference be held at the Museum of the Great Plains in Lawton, Oklahoma, in conjunction with the Plains Conference, but a mail poll produced an overwhelming vote in favor of meeting at the University of Texas (UT) in Austin. Although Austin is 200 miles southwest of the nearest Caddo site (unless the Caddo-like pottery on the Central Brazos near Waco signified actual Caddo residence), the amount of Caddoan archeology carried out by the University of Texas meant that there were people and collections there to make a meeting appropriate.

No formal program was drawn up for this conference, but in the mailed announcement, three major topics were listed for discussion, each to be introduced by a fairly formal statement: "1. New information on pre-Caddoan Archaic complexes, introductory statement reviewing the Yarbrough site data by LeRoy Johnson, Jr.; 2. Historic sites and European trade material, introductory statement on Titus Focus-like material in the Norteño Focus, by E. B. Jelks; 3. Culture change and variation within the Fulton Aspect, introductory statement on Titus Focuslike material in the Ferrell's Bridge Reservoir area, by Mott Davis." The discussion was recorded on tape, and mimeographed proceedings were completed, but were not edited and/or distributed at the time.

The conference took place in the battered old Little Campus archeology laboratory of the Department of Anthropology at UT, an antiquated and honored facility that had housed the efforts of many generations of Texas archeologists. The principal participants sat around a long table, with Ed Jelks or Clarence Webb at one end, with others in a wider ring around them (Figures 4 and 5). 


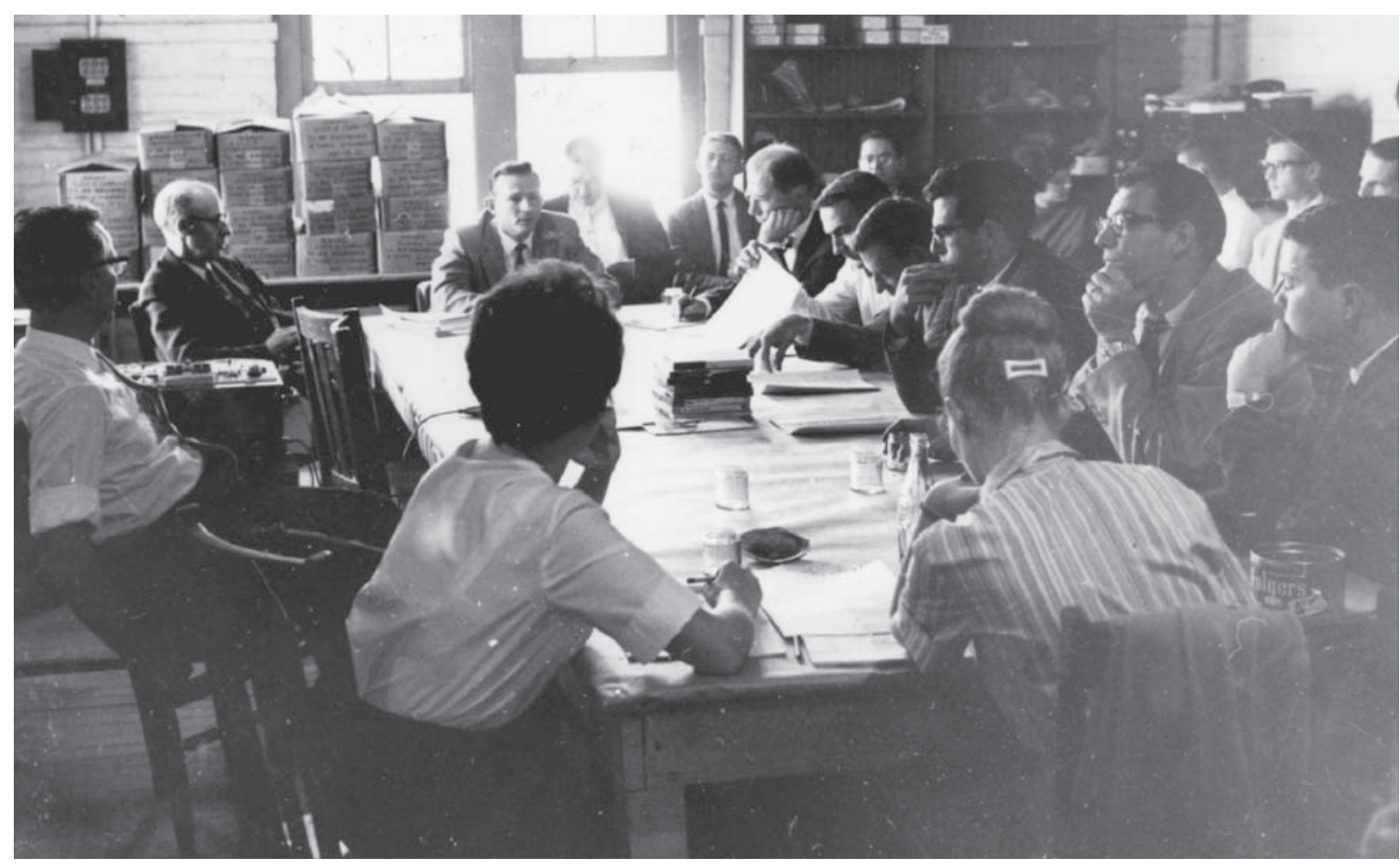

Figure 4. 1962 Caddo Conference in Austin, Texas. Foreground, taking notes: JoAnn Parsons and Margaret Wheeler. Left to right: E. Mott Davis (leaning back on chair), Bob Bell, Ed Jelks (at head of table leading discussion), Marvin Tong (in front of window), Adrian Anderson (besides Marvin), Clarence Webb (head on hand), Bill Mayer-Oakes (holding up end of paper), Barnard Golden (above Mayer-Oakes' head, in front of wall case), Jerry Epstein (at table, head leaning forward, hand gracefully out on paper), Lathel Duffield (hand to mouth next to Epstein), Ray Wood (hand to chin next to Duffield). In back, between Duffield and Wood, student Molly Hayes talking to someone obscured, perhaps Dan Scurlock (also student), Pete Gregory (hand to mouth next to Wood). Above Gregory's head: physical anthropology student William Maples and Kenneth Bennett. Identifications by E. Mott Davis.

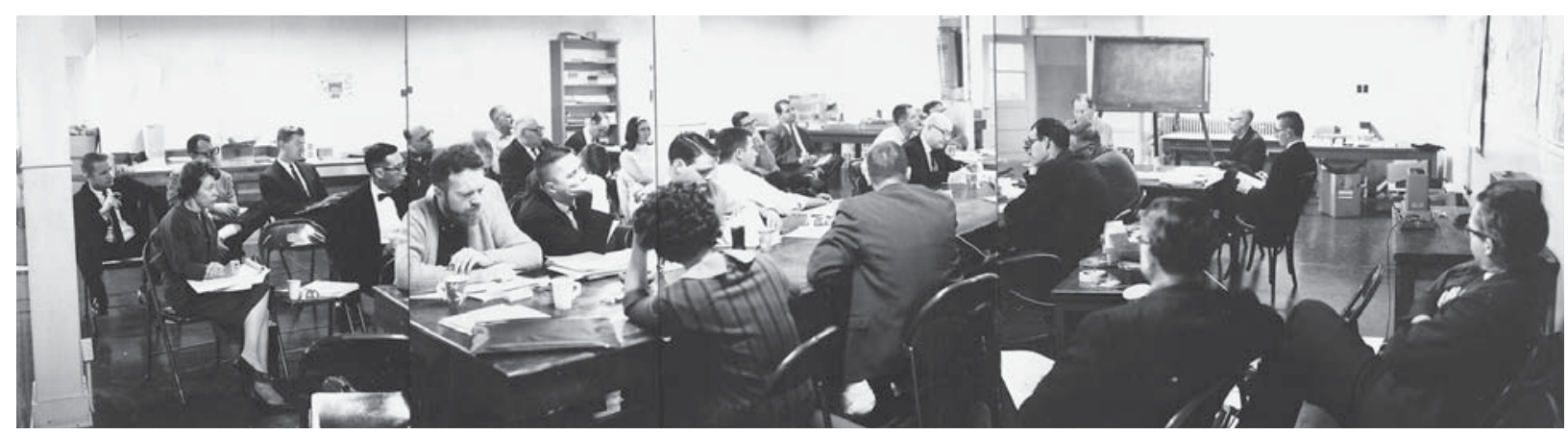

Figure 5. Panorama of participants in the 1962 Caddo Conference. Clarence Webb is at the head of the table, his head showing directly below the black board on his right.

Before the main topics were taken up, William Maples, a graduate student in physical anthropology at UT, presented his analysis of skeletal material from the Sanders site and several Fulton Aspect sites, which he was then putting into final form for his Master's thesis. He had found that the Sanders population was essentially the same as those from the Fulton Aspect sites (broad high skulls, long faces with long slender noses, high orbits, and mesostaphyline palates). In the discussion that followed, however, the need for more such studies was most apparent. After Maples' presentation, Jerry Epstein (UT) told briefly of the burins he had been finding in 
a number of lithic assemblages in Texas, mostly in the lower Pecos area. This specialized type of flint tool was not familiar to most of the persons at the conference, and Epstein wanted to alert everyone to the possibility that there might be burins in their collections.

The first major topic was then taken up: "New information on Archaic Complexes in the Caddo Area." Initially there were informal reports from each part of the Caddoan area on what was known of Archaic and Paleoindian materials. This discussion emphasized the meagerness of the data, most of it in the form of surface finds. Then there were more formal statements of recent investigations: LeRoy Johnson, Jr. on the Yarbrough and Manton Miller sites [the former excavated during the WPA period and the latter in 1959, but only recently analyzed], Mott Davis on the Jake Martin site at Lake O' the Pines, Lathel Duffield on the Wolfshead site at Lake Sam Rayburn, and W. W. Crook, Jr. on sites in North Texas. Much of the ensuing lengthy discussion revolved around the nature of the changes from Paleoindian to Archaic and from Archaic to Caddoan, and how one can or cannot define such changes on the basis of field evidence.

The next topic, on historic sites and European trade material, was introduced by Jelks with a review of his studies of sites in North Texas on the basis of which he had formulated the Norteño focus, representing the protohistoric and historic Wichita tribes. Clarence Webb described the artifacts from an 1820s Biloxi site below Natchitoches. In these presentations and the discussion that followed, the many kinds of European trade materials found in contact sites - ceramics, gun flints, and other gun parts, beads, and so on-were considered in detail.

The final subject was "Culture Change and Variation within the Fulton Aspect." Since the Caddoan foci had been defined as static entities, it was desired to see what the archeological record revealed about changes. Mott Davis presented the evidence that the Whelan complex is a precursor of the Titus focus. Webb reviewed the story of the Belcher Mound, an example of Caddo culture changing through time. He proposed that studies of change should focus on traits rather than complexes, and it was agreed that the theme of the next conference should be the distribution of individual traits in the Caddoan area. It was emphasized that there is a sore need for re-examination of old formulations, such as Krieger's foci, which had been set up on the basis of evidence that could no longer, in the light of more recent work, be considered adequate.

After a presentation by Hester Davis about the looting going on at the Crenshaw site in Miller County, Arkansas, on the Red River, the conference passed a formal resolution condemning the looting and emphasizing the need for site protection in the Caddo area.

It was agreed that the next conference would take place at the University of Arkansas Museum in Fayetteville, that an agenda would be sent out ahead of time, and that the participants would come prepared with specimens and detailed data on the distribution of attributes and types.

\section{Here endeth the reading of the draft edited manuscript prepared by Mott Davis in 1983.}

Hereafter, the accounts of the conferences may be a bit spotty, because as far as I can make out there has been no attempt to keep "official" archives-in keeping with the nature of the Conference. Several conferences were taped but the tapes were not transcribed and as I mentioned previously, are probably not retrievable now. I have a copy of all the rest of the programs, but that is not the same as what may have actually been presented and sometimes does not record any other activities. Mott did actually make notes which he summarized by meeting up to the $25^{\text {th }}$ Caddo Conference. However, he gave the presenter's name and the topic of the paper or discussion and that is it. It would be possible to take these summaries and compare them with the printed program. If a name in the program is not on Mott's list, the assumption is that that person did not give the paper; if there 
is a name on Mott's list that is not in the program, then that person made a presentation instead of the person who was not there. I have not done that in the discussion that follows because it seems to me the program's listed discussions and titles of presentations will give a good idea of the location and the nature of the research going on in the Caddo area.

\section{3, Seventh Conference, Fayetteville, Arkansas, March 29-30}

The conference was held, seminar style, in a small room on the fourth floor of Old Main, the floor which held the University Museum (Figure 6). The room had been chosen because it was next door to the Museum's curation room which held ca. 6000 whole pottery vessels. It was easy for the "experts" to ask for a particular decorative type, or shape, and someone knowledgeable would go and find an example.

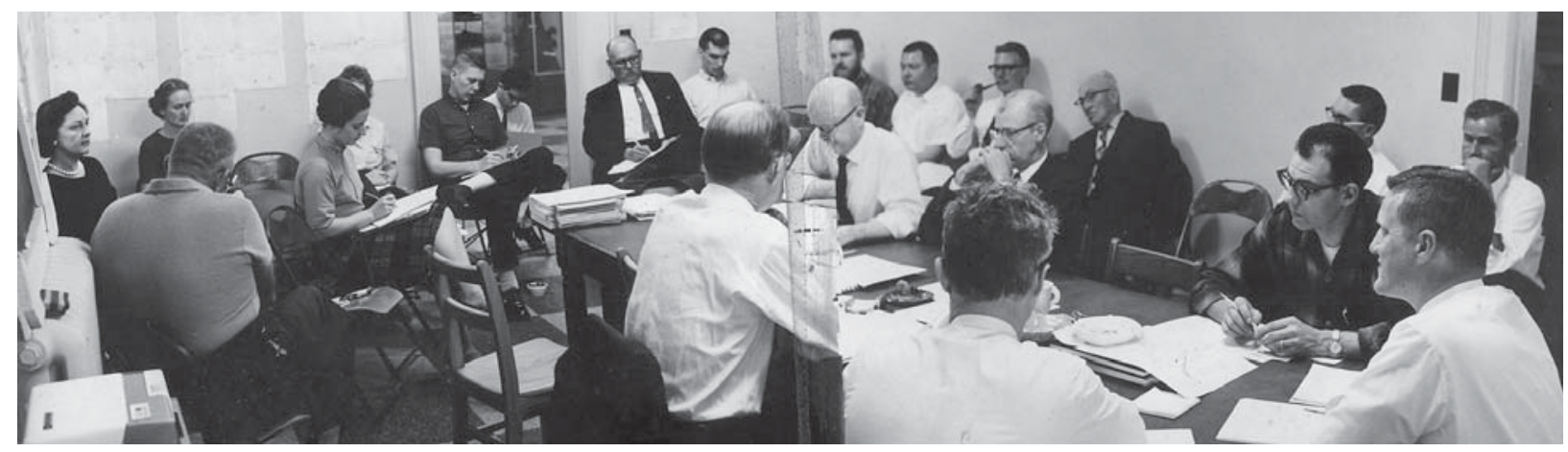

Figure 6. Seventh Caddo Conference. Left to right around the table, beginning with the back of the man in the foreground on the right: E. Mott Davis, Clarence Webb, Jimmy Griffin, Bob Bell, Ray Wood, and Bob McGimsey. Starting on the left, around the room: King Harris (back to camera), Mrs. King Harris (?), Mamie Ferguson, Margurite Verley (behind her is her mother, obscured), Fred Bohannon, Ron Thomas, Pete Shiras, Jim Toney, Jim Scholtz, Smoke Moore (NPS archeologist working at Fort Smith), Clyde Dollar (with pipe), Harry McPherson, and Don Wyckoff.

There were 26 people in attendance, most of whom were there for all the sessions. The participants were as follows (from Davis et al. 1971a):

*Robert E. Bell, University of Oklahoma

*C. Fred Bohannon, National Park Service

Deane Carter, Fayetteville

*E. Mott Davis, University of Texas

*Hester A. Davis, University of Arkansas Museum

*S. C. Dellinger, University of Arkansas

Clyde Dollar, National Park Service

Mrs. J. C. Ferguson, Fayetteville

*James B. Griffin, University of Michigan

Mr. and Mrs.* R. King Harris, Dallas

*Buddy Jones, Greggton, Texas

*Charles R. McGimsey III, University of Arkansas Museum

Ralph McKinney, Hosston, Louisiana

Harry R. McPherson, Fayetteville

Jackson (Smoke) Moore, National Park Service

*Gregory Perino, Gilcrease Institute, Tulsa

*James A. Scholtz, University of Arkansas 
Pete Shiras, Mountain Home, Arkansas

Ronald A. Thomas, University of Arkansas Museum

James T. Toney, University of Arkansas

*Marguerite Verley (and her mother), Homewood, Illinois

*Clarence A. Webb, Shreveport, Louisiana

*W. Raymond Wood, University of Arkansas Museum

*Don G. Wyckoff, University of Oklahoma

(*Those whose names are starred, contributed to the discussions).

The following description of the meeting is taken from the 1963 The Arkansas Archeologist (IV(5):11):

Friday morning's session was led by Bob McGimsey and consisted of a series of informal reports on field work. Ray Wood summarized his findings at the Crenshaw site [Wood 1963], and his analysis of the Poole site in Garland County [Wood 1981]; Fred Bohannon reported upon his National Park Service work at the Mineral Springs site in Howard County [Bohannon 1962, 1973]; and Clarence Webb told of the excavations he and Ralph McKinney had been conducting in the Mounds Plantation site in northwestern Louisiana [Webb and McKinney 1975]. In the afternoon, Dr. Webb led discussion on the distribution (in time and space) of specific pottery types and their decorative techniques. This session managed to cover simple single-line incising and engraving, as in Coles Creek, Greenhouse, Chase, and Hardy Incised, and multiple straight and diagonal line decoration as in Dunkin Incised. Effigy appendages associated with these decorations were also brought in [from the curation room] for discussion.

Friday evening there was a "social gathering” with song, fellowship, and even "moom' pitchers"[Of which I have no memory or evidence!] for relaxation at the McGimsey's house. [Figure 7. This is the first record in my files of the social part of the Conference.]

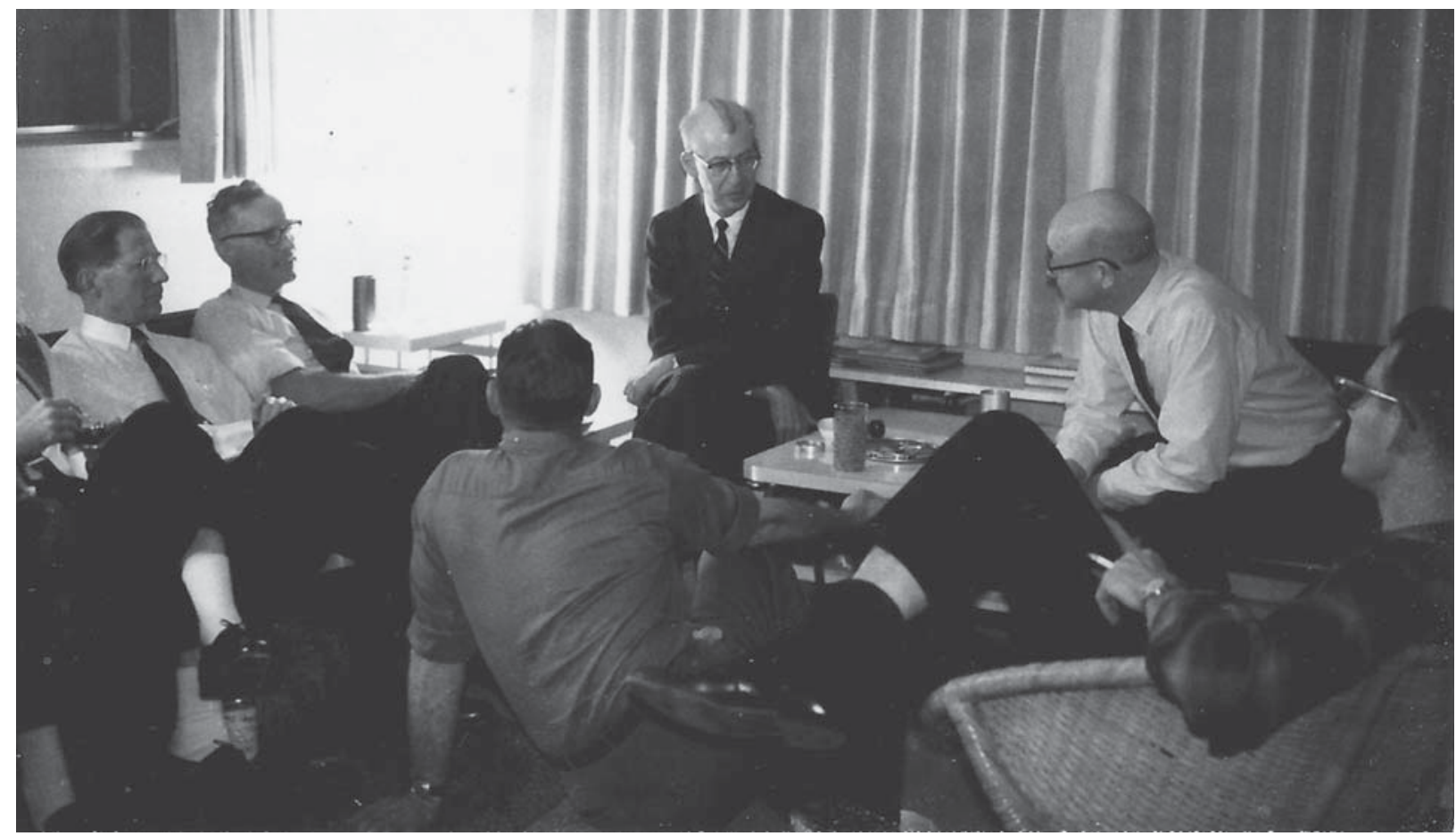

Figure 7. Bob McGimsey's living room. Left to right: Clarence Webb, E. Mott Davis, Bob Bell, and Jimmy Griffin. Greg Perino is sitting on the floor, with Ray Wood to the right. 
The following morning the session was led by Bob Bell of the University of Oklahoma and revolved around the distribution and types of mounds and burials within the Caddoan area. Much new information was brought out on these subjects, which has only been lightly covered in past conferences.

Saturday afternoon we spent a couple of hours bringing our trait lists up to date by adding information which had been mentioned during the discussions [see H. Davis et al. 1971a].

The session ended around 4:00 o'clock, and after everyone left we realized we had not discussed when and where next year's meeting would be held.

All the sessions had been taped. The field reports were transcribed and edited by Hester Davis separately from the discussion sessions, and were published by the University Museum in mimeographed form in 1966, along with the field reports from the Eighth conference held in Norman, Oklahoma (Davis 1966). The discussions were also taped and transcribed and were published by the Oklahoma Archeological Survey as Occasional Publication No. 1 (Davis et al. 1971a).

\section{5, Eighth Conference held in Norman, Oklahoma, February 19-20}

Since no plans were made at the Fayetteville meeting as to who would host the next meeting we skipped a year between conferences. This meeting was held in the Laboratory of the Oklahoma River Basin Salvage Project, where material from Oklahoma's recent excavations was spread out (Figure 8). About 35 people were in attendance, but there is no list in the files.

As had become traditional, field reports were presented first to bring everyone up to date on what had been going on where. Mike Hoffman, Jim Scholtz, and Dee Green reported on the work in southwest Arkansas: in

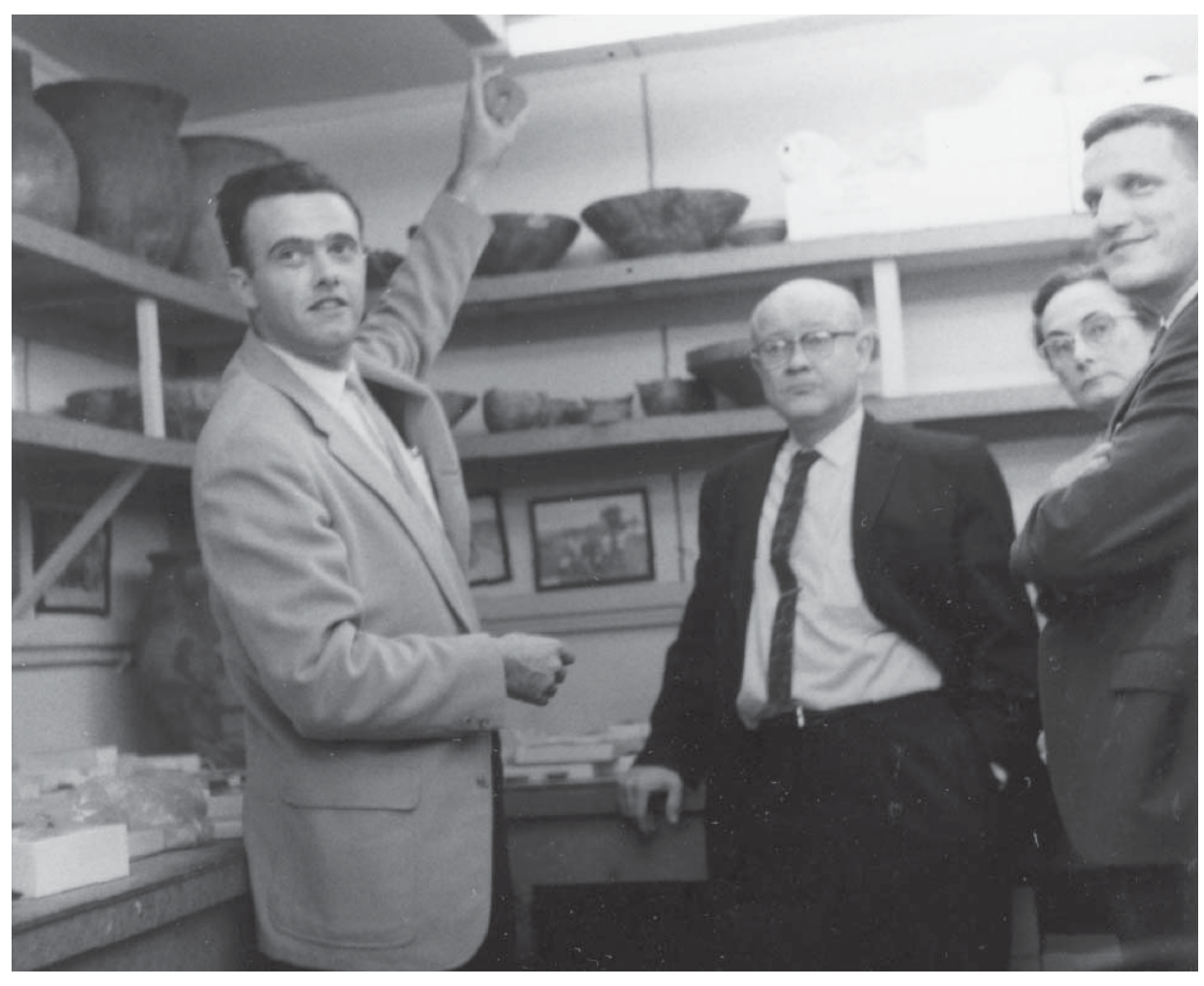

Figure 8. Left to right: Jim Brown (brandishing a Spiro artifact: spindle whorl? gorget?), Jimmy Griffin, Jean Hamilton, and Bob McGimsey. 
Millwood Reservoir, six sites had been tested: Old Martin Place, Graves Chapel, Hutt, Beard Lake, Stark, and White Cliff (Hoffman 1969, 1970). Jim Scholtz reported on excavation at Dillard Mound in Clark County, which was to be affected by the Arkansas Highway Department; Jim and Dee Green discussed excavations at the Powell Mound site in Clark County (Scholtz 1986), scheduled to be inundated by DeGray Lake. Mound A was flat-topped with a $6 \mathrm{~m}$ diameter structure on its summit, and with another structure under the mound. Mound B was a single-stage man-made mound, but its function is unknown. The artifacts indicated the site was occupied by Coles Creek and Gibson Aspect Caddo, but the mounds were built later during a Haley Focus occupation. Webb reported on northwestern Louisiana work, where excavations had uncovered Paleoindian, Tchefuncte, and Coles Creek sites, and radiocarbon dates had been obtained for Mounds Plantation and Belcher Mound sites. In Texas, Dee Ann Story reported on work in the McGee Bend and Cedar Creek Reservoir areas, and Burney McClurkan discussed sites in the Toledo Bend Reservoir: Hurricane Creek, Ammons, Bison, and Coral Snake Mound. Much work had been accomplished in Oklahoma: Wyckoff reported on seven sites in Broken Bow Reservoir: Beaver, Hughes, Lamas Branch, Johnson, Callaham, Woods Mound Group, and Biggham Creek. Tom Barr, a graduate student at the University of Oklahoma, reported on Pine Creek Reservoir sites: Bell, Baldwin, and Belk. Ray Wood, from the University of Missouri, reported on the Eureka mound site in Dade County, Missouri. A Spiro Engraved water bottle had been found in a small rock and earth mound in the Stockton Reservoir area, southwest Missouri (Figure 9, see Wood and Pangborn 1968).

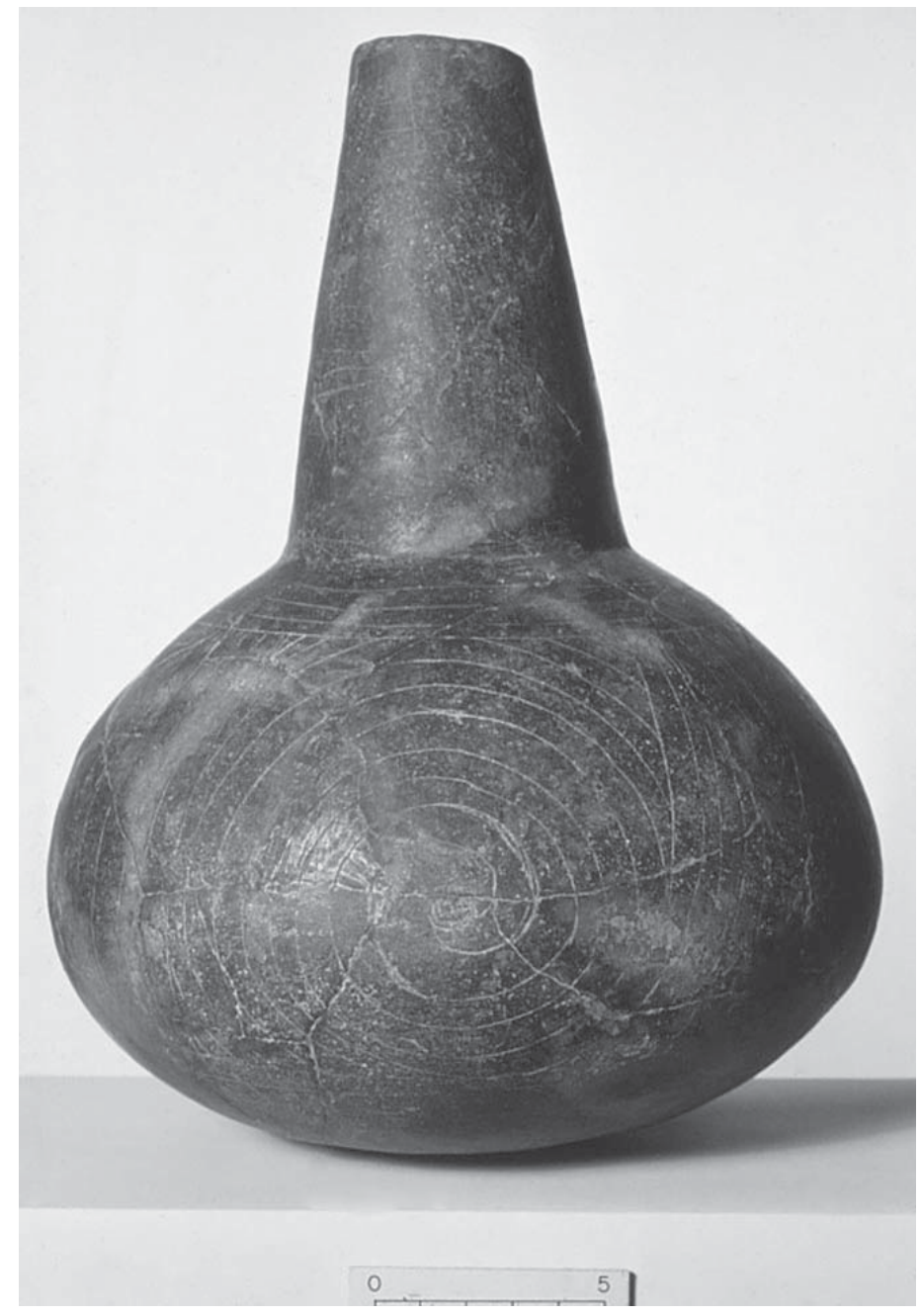

Figure 9. Spiro Engraved bottle from the Eureka Mound site in southwest Missouri. Image courtesy of W. Ray Wood. 
Friday afternoon the research reports continued, because Bob Bell and Jim Brown had long reports-Bell on his work at the Harlan site and Jim on the Spiro material. The transcription of all these reports can be found in with those from the Seventh Conference in Davis (1966).

Saturday was spent discussing four general topics: Information on Pre-Caddoan occupation in the area; information on Coles Creek occupation in the Caddoan area; the relationships between the Caddoan development and the development of cultures along the Mississippi valley; and the transition between Gibson and Fulton Aspects. These are topics discussed at previous meetings, but so much information was beginning to be unearthed that it was important that everyone be exposed to all this new data. The transcription of these discussions were edited by Davis, Wyckoff, and Holmes (1971b), and published in 1971 as Occasional Papers No. 2 of the Oklahoma Archeological Survey.

Friday evening, the social-networking part of the Conference got under way when just about all the participants went to Jimmy Durham's house in Oklahoma City to visit his "museum," a small concrete block two room building in which he housed his collection. Most particularly the group went there to see the material which Jimmy had purchased from those who dug at the Crenshaw site-artifacts which were from graves that seemed to have similarities to some of the material found with burials at Spiro (see Durham 1964; Durham and Davis 1975; Durham and Kizzia 1975).

\section{6, Ninth Caddo Conference, Natchitoches, Louisiana, February 4-5}

This conference was held on the campus of Northwestern State College (now University) in Guardia Hall. The file on this conference is almost bare, except for the transcript of all the sessions, and a wonderful story by Ed Jelks which is at the end of the summary of the conference itself. Tim Perttula agreed to edit the transcripts, and these are to be published in a future volume of the Caddo Archeology Journal (Perttula n.d.). Let me say, however, in the interest of those not wanting to read through the whole thing, that Tim has a short summary (similar to what is included about the conferences in this history) in his introduction. In addition, Mott has a cursory summary, and now I will take some of both of these sources to make my own summary.

As usual, field reports took up the first morning, with Mike Hoffman giving a lengthy review of work in southwest Arkansas, Jim Brown on Spiro, Tom Barr on work in the Webbers Falls area on the Verdigris River in east-central Oklahoma, and Bob Bell reporting on Wyckoff's continued work in Broken Bow and Pine Creek reservoirs in the southeast corner of Oklahoma. Burney McClurkan discussed work at the Livingston Reservoir and in Toledo Bend Reservoir on the Coral Snake Mound and the Salt Lick site. Webb reported on what had been found at the Resch site, also in Texas.

The second session related to the southern part of the Caddo archeological area, including early pre-A.D. 900 sites, the origins and extent of sandy paste pottery, and on relationships with Lower Mississippi Valley groups.

Saturday morning was devoted to historic materials, with a long discussion based on Jay Blaine's studies of guns and gun parts, and a report by Tom Barr on excavations of a $19^{\text {th }}$ century trading post on the Verdigris River (not in the transcripts as it was outside the Caddo area).

The final session, according to Mott's summary, was presided over by Webb and centered on a critical review of the Gibson-Fulton concept, including its history, and examination of the meaning of "Gibson Aspect-how much is it based on ceremonialism alone? What did pre-Gibson (Coral Snake, Fourche Maline, etc.) contribute 
to Gibson?" Webb suggested that there are not two divisions (Gibson and Fulton), but four or five. "We must assemble chronological data and construct a Caddo chronology." It is agreed to do so at the next conference.

And now to Ed Jelks' promised story. We know full well that this is not an isolated incident in the annals of the conference, for some sort of entertainment was either planned by the hosts or came upon some of the attendants spontaneously:

I will add an anecdote about some extracurricular activity that took place at the Caddo Conference at Natchitoches in the 1960s [this is the only conference in Natchitoches in the 1960s. However, there is another published version of this story, also by Jelks, which indicates that this escapade may have taken place at one of the 1970s meetings in Natchitoches, see Jelks (1995)].

One evening after the meeting had adjourned, Judy [Ed's wife], Kathleen Gilmore, and I were enjoying happy hour, with, I believe Norma [Hoffrichter], and maybe someone else, when Kathleen said "I think De Mezieres [ $18^{\text {th }}$ century French explorer] is buried in Natchitoches. Let's go look for his grave." That sounded like a great idea, so after asking directions, we found the cemetery and were roaming amongst the gravestones with a flashlight reading inscriptions, when a police car came roaring up and screeched to a halt. Two officers built like NFL linebackers with no-nonsense scowls on their faces approached and said "You are in violation of the evening curfew. What the hell are you all doing out here in the cemetery anyway?" It had to have been obvious to them that we had been drinking, maybe more than we should have been. These guys scared me, but Kathleen wasn't fazed at all. With the sweetest smile imaginable, she said "My goodness, officers, we had no idea there was a curfew. We were just looking for the grave of Athanase De Mezieres." One officer asked the other "Do you know this guy De Mezi-something?", to which his partner replied, "Never heard of him." Then to us: "Was he a friend of yours?" "Oh, yes," murmured Kathleen demurely, "a very dear friend."

"Well I guess you are not doing any harm. Take a few more minutes to look, then get off the streets." And they got in their car and drove away. We continued searching for a while, but I don't think we ever found De Mezieres' grave."

\section{7, Tenth Caddo Conference, Dallas, Texas, March 11}

This conference, organized by Ed Jelks (who was Associate Professor at Southern Methodist University at the time), broke with "tradition," by being planned for just one day. There is in my file only a copy of the announcement, a list of those attending, an invitation from Bill and Mary Crook for everyone to come to their house for a social gathering starting at $7 \mathrm{PM}$, and a page of my own notes. The whole session may or may not have been taped, but what is in my files is an eight page transcript of the portion dealing with ideas and plans for the $11^{\text {th }}$ Caddo Conference. After the list of attendees, you will find Ed's announcement quoted verbatim in all its Edwardian glory:

Those who attended were:

Lawrence E. Aten, Houston, Texas

Byron L. Barber, Dallas, Texas

Tyler Bastian, Norman, Oklahoma

Robert Bell, Norman, Oklahoma

Mr. and Mrs. Jay C. Blaine, Dallas, Texas

Frank J. Brezik, Jr., Houston, Texas

Mr. and Mrs. Herschel Cobb, Dallas, Texas

E. Mott Davis, Austin, Texas 
Hester A. Davis, Fayetteville, Arkansas

Mr. and Mrs. W. A. Davis, Jasper, Texas

Mr. and Mrs. W. L. Fullen, Deer Park, Texas

Mr. and Mrs. Jon Gibson, Dallas, Texas

Kathleen Gilmore, Dallas, Texas

James B. Griffin, Ann Arbor, Michigan

George P. Grove, Wood River, Illinois

Mr. and Mrs. R. King Harris, Dallas Texas

Larry Head, Texarkana, Texas

Michael P. Hoffman, Fayetteville, Arkansas

Norma Hoffrichter, Dallas, Texas

Mr. and Mrs. Oscar W. Horn, Jasper, Texas

Mark E. Huff, Jr., Dallas, Texas

Isabelle Lobdell, Fort Worth, Texas

Hal Jensen, Dallas, Texas

Paul and Dessamae Lorrain, Dallas, Texas

Burney B. McClurkan, Austin, Texas

Scott McKern, Dallas, Texas

Parker Nunley, Natchitoches, Louisiana

Gregory Perino, Tulsa, Oklahoma

Charles Rohrbaugh, Norman, Oklahoma

John G. Saunders, Houston, Texas

Fred Schneider, Norman, Oklahoma

James and Sandra Scholtz, Fayetteville, Arkansas

Joe N. Shurtleff, Texarkana, Arkansas

Pete Shiras, Mountain Home, Arkansas

C. A. Smith, Jr., Dallas, Texas

Quinby Smith, Mountain Home, Arkansas

Ron Wetherington, Dallas, Texas

Robert L. Turner, Pittsburg, Texas

Clarence H. Webb, Shreveport, Louisiana

Joe B. Winters, Tulsa, Oklahoma

Don G. Wyckoff, Norman, Oklahoma

This year's Caddo Conference will be held at SMU on March 11. The conference will convene at 9:00 am in Room 203, Selecman Hall, and will continue without interruption (except for a lunch break) until everyone is sick of arguing or until 5:30, whichever comes first.

The topic for discussion will be: A CRITICAL REVIEW OF THE GIBSON-FULTON CONCEPT. To be explored, in particular, are the questions of (a) whence [came] the cultural base or bases from which the Caddoan tradition developed, and (b) should the original Gibson-Fulton concept be modified in the light of present knowledge.

This will be a working conference with the aim of either arriving at a consensus or positing clearly any conflicting stands. There will be no prepared papers. The center of the arena will be occupied by a selected panel of "experts": people who have done major field work in, and/or theorizing about, Caddoan Area Archeology. Clarence Webb and Robert Bell will chair, respectively the morning and afternoon sessions. Under their expert prodding, the panel will - it may be confidently predicted-discuss the Gibson-Fulton problem with all the zeal, vigor, and eloquence that has come to be expected of dedicated Caddo-ologists in action.

Noncaddo-ological archeologists, students, and all other interested parties are invited to attend the conference. They will be encouraged to ask questions of the panel, contribute comments, or even make impassioned speeches if they are so inclined. 
My notes indicate there was a detailed review of the traits of each Aspect which seems to have taken up the whole morning. One assumes that the afternoon session discussed the wider issues of the "cultural base."

Between the $10^{\text {th }}$ and $11^{\text {th }}$ conferences, the portion of the $10^{\text {th }}$ dealing with the ideas and plans for the next conference were transcribed and distributed, in particular the question of whether the Gibson/Fulton concepts needed updating. McGimsey called Krieger, now teaching at the University of Washington, inviting him to the 11th meeting in Arkadelphia. A copy of the transcribed portion of the meeting was sent to him as well. A portion of his return letter is partly quoted below, allaying the group's fears that he would not like the idea of the expected "surgery" on his classification:

I am very content to have your conference rake over the whole business, and if possible or feasible, make a completely new framework. If you or anyone thinks that I wish to make a defense, the answer is no, I do not, and that personally I realize all too well that everything we archeologists cook up must sooner or later be revised or completely redone. New field information, more radiocarbon datings, and more detailed trait comparisons over extensive areas should and will demand new ideas about how to organize and interpret the whole mass. If I can make one positive statement it is that far too many of us are overly concerned with more or less exact datings, and too little concerned with mapping out specific features or traits in their ultimate distributions; traits that are of very general distribution (in the Caddoan area or the whole eastern US or anywhere) should be weeded out as not diagnostic of anything in particular so that more efforts can be made to define and map traits that are diagnostic of such and such cultural units but not others. This basic problem exists everywhere but it is seldom if ever really treated with the care that is really needed.

... I just wanted you and your colleagues to know how I stand on your plans, and that I could not possibly have any objection to the sort of "surgery" that is indicated; the need for it has long been apparent and I am happy that someone is in the mood at last to try it (letter from Alex Krieger to Hester Davis, March $11,1968)$

\section{8, Eleventh Caddo Conference, Arkadelphia, Arkansas, March 15-16}

This was the largest meeting so far, with 85 people signing in (not listed because that is too many and all are handwritten and some are illegible). The Arkansas Archeological Survey had been created as of 1 July 1967, and there was now a Research Station at Henderson State College (now University), with Jim Scholtz as Survey Archeologist. A note on the registration list says there were 53 people at a reception at Jim and Sandy's house on Friday evening. That occasion I remember well, because 53 people could barely fit in the house, and as a consequences there was a good deal of elbow nudging to reach the refreshments, and people had to spill out onto the porch on a cool early spring evening.

The subject of the meeting, Caddoan Chronologies, was obviously of interest to lots of people. The discussions were recorded and have been transcribed but not edited or published. Many people brought charts showing what was known of the chronology in their area or at particular sites. After a full morning of field and research reports, the Friday afternoon session, moderated by Clarence Webb (Figure 10), reviewed the regional sequences using trait lists and formal definitions of phases and chronological divisions. Saturday morning and some of the afternoon was devoted to construction on a blackboard of Tentative Caddo Chronology, stages I through V. The end of the day was a discussion moderated by Jimmy Griffin on chronologies in "peripheral" areas (Figure 11).

We must have exhausted ourselves at this meeting, for we again skipped a year before the next one. 


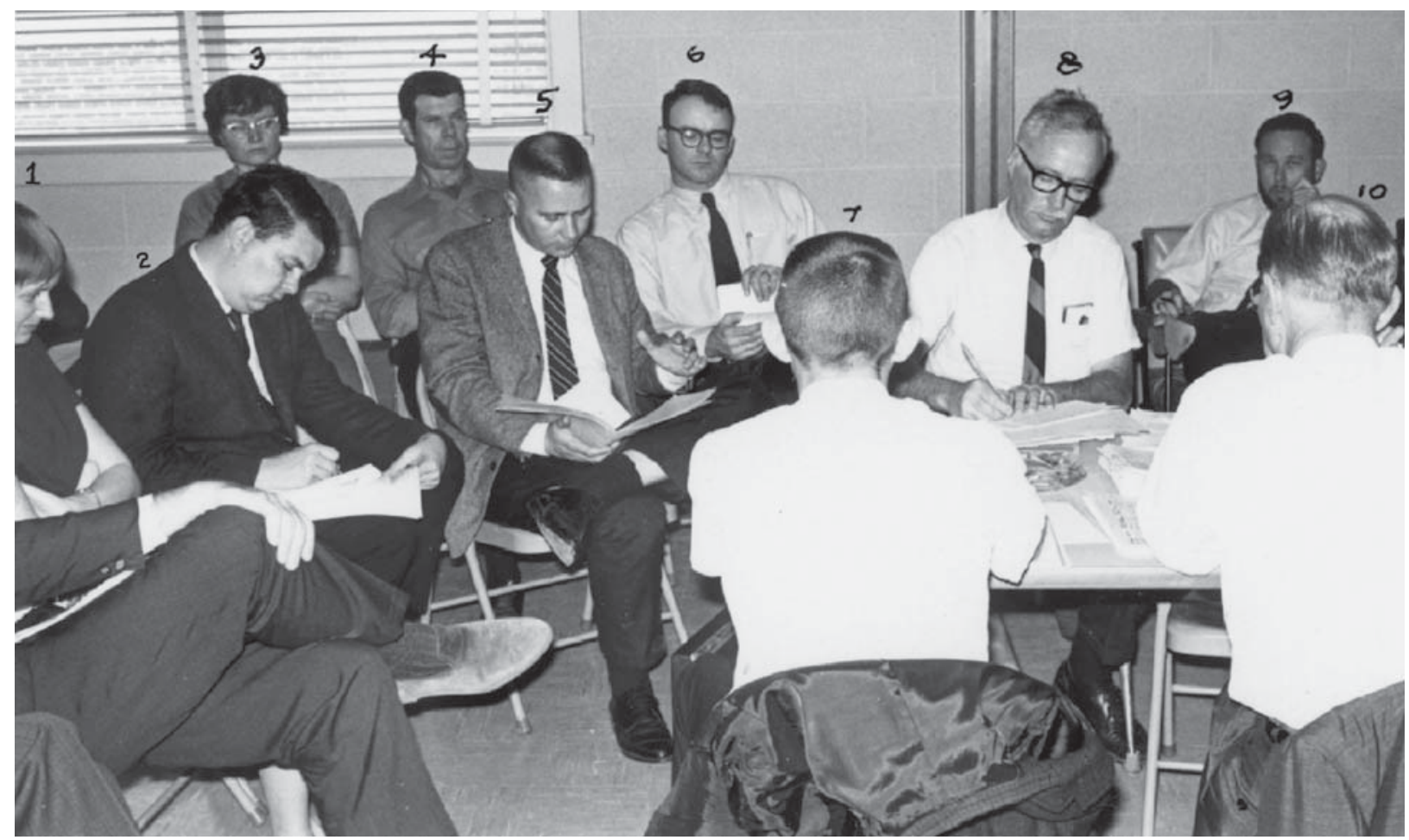

Figure 10. Eleventh Caddo Conference session. Left to right: (1) Phyllis Morse (face only), (2) Pete Gregory, (3-4) Mr. and Mrs. Bill Davis, (5) Mike Hoffman, (6) Frank Schambach, (7) Don Wyckoff, (8), Mott Davis, (9) Glen Greene, and (10) Clarence Webb.

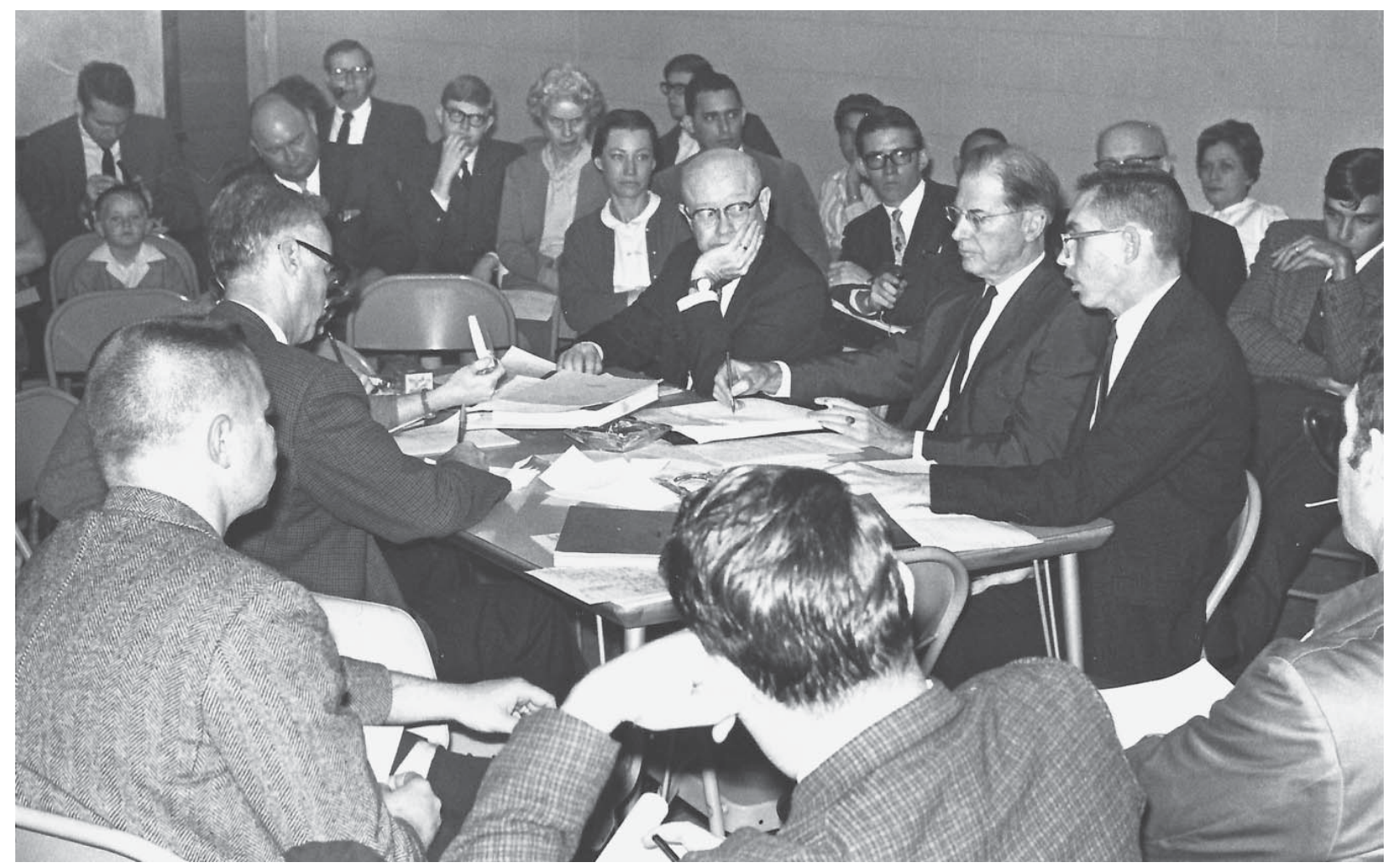

Figure 11. Another session at the Eleventh Caddo Conference. Jimmy Griffin, Clarence Webb, and Don Wyckoff on one side of the table, Mott Davis (with his back to the camera) on the other side. 


\section{0, Twelfth Caddo Conference, Magnolia, Arkansas, March 20-21}

The meeting was held at Southern State College (now Southern Arkansas University) in a conference room in the Student Union. There were around 75 people in attendance (Figure 12). Some of the field reports have been transcribed but not edited; Mott's notes on other parts of the conference are handwritten.

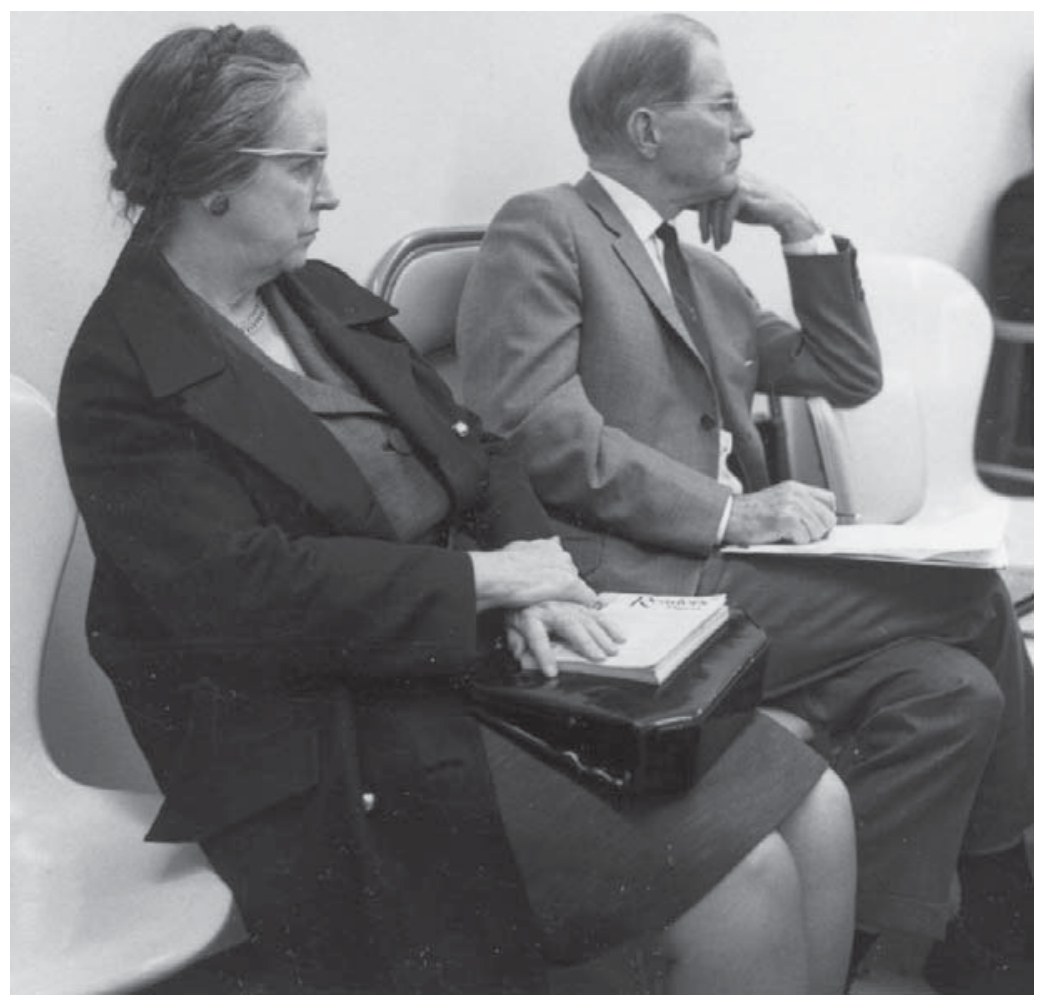

Figure 12. Dorothy and Clarence Webb.

Friday was devoted to field and research reports, six given in the morning and six in the afternoon (Figure 13). The program gives them formal titles and the transcript indicated people had slides; the program reads as if these were written papers (there is in my files a copy of a paper by Harry Shafer on lithics from the Davis Site). If that is so, it is the first time that formal papers were read. Saturday was devoted to major discussions: Fourche Maline and its role in the formation of Caddo culture; and Coles Creek and its role in the formation of Caddo culture.

For the first time, also, Schambach had arranged for a dinner and speaker for Friday night. James Howard, an ethnologist at the University of Oklahoma, gave a talk on "The Southeastern Ceremonial Complex and Its Interpretation" (Howard 1968).

\section{1, Thirteenth Caddo Conference, Austin, Texas, March 27}

This was another one day conference, but there was an evening session, from 7-9 PM, as well. The meetings were at the Applied Research Laboratory at the UT Balcones Research Center. On Friday evening, before the formal program began on Saturday, there was an open house at Mott and Beth Davis' home, from 7 PM until "we sweep everyone out at 11, so that all will be pert and alert for the conference the next day." 


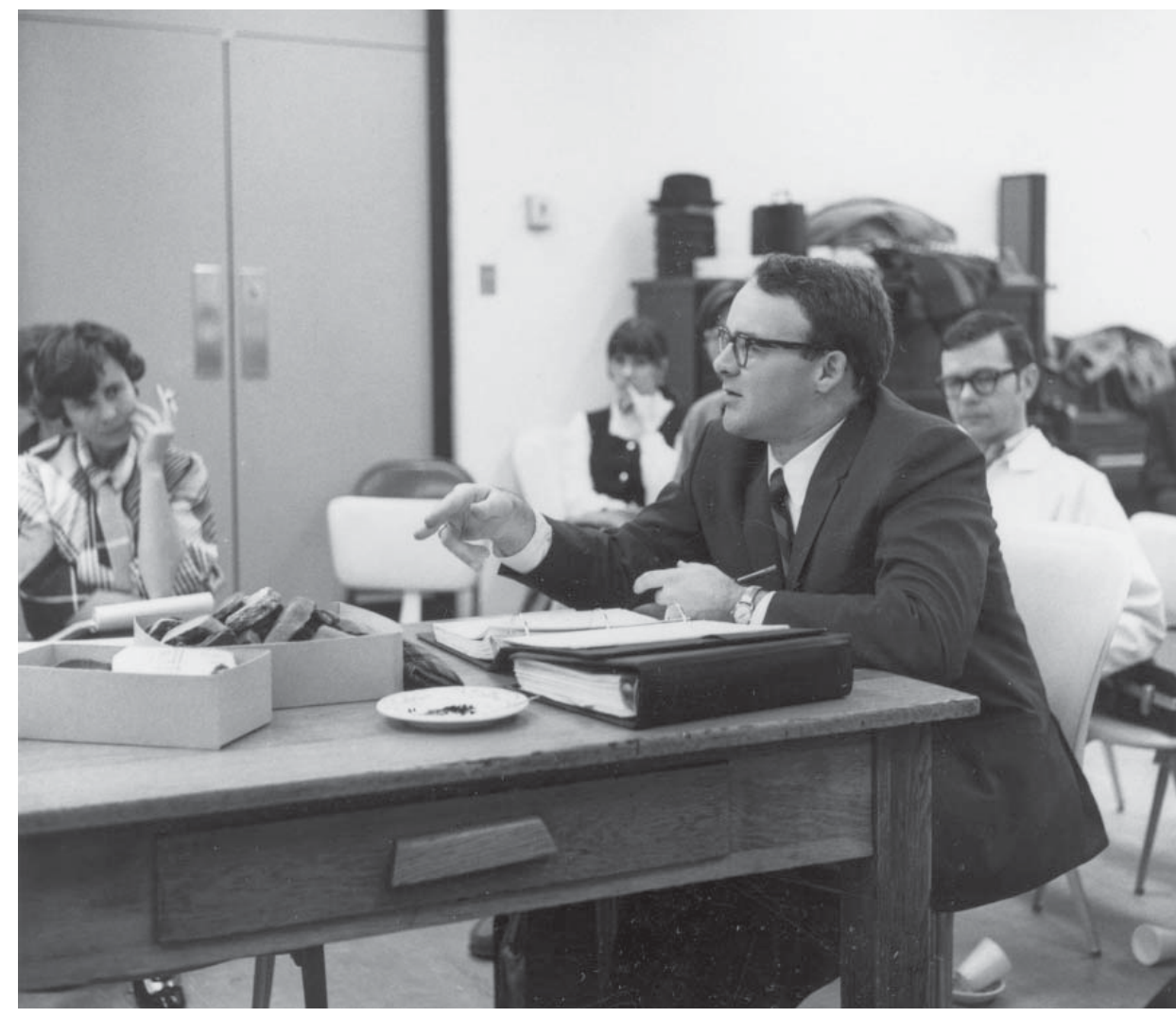

Figure 13. At left, Dee Ann Story; Frank Schambach at the table; the two individuals in the background are unidentified.

As usual, Saturday morning was devoted to field reports. Saturday afternoon there were two longer presentations. The speaker and discussants sat around a table, but everyone was encouraged to take part in the discussions (Figure 14). The two papers were: "The Concept of the Trans-Mississippi South as a Culture Area" by Frank Schambach, and "Implications of the Information from the 1968-1970 Work at the George C. Davis Site," by Dee Ann Story. This was Frank's first presentation of his concept for the Trans-Mississippi South as a particularly influencing cultural and natural area and it has generally been accepted as a useful concept.

Mott's notes indicate that "Hester Davis gave a report on progress, or lack thereof in Congress, on the MossBennett legislation," which would free federal agencies to spend their own project money for cultural resource work required by the National Historic Preservation Act of 1966, instead of the National Park Service having to get a big enough appropriation to fund all the necessary work.

Saturday evening at the Archeology Lab at Balcones, there were "Tech Sessions": small groups discussing particular topics of interest and looking over relevant materials in the collections. There was also the opportunity for a guided tour by Mott Davis of the Radiocarbon Laboratory.

\section{2, Fourteenth Caddo Conference, Tulsa, Oklahoma, March 18}

This meeting was held at the Thomas Gilcrease Institute of American History and Art, and there was a reception at the Gilcrease Institute on Friday evening. "This is your opportunity to tour the galleries. All point types in the Gilcrease collection are on display and there is a special exhibit of early points from the Caddoan area." 


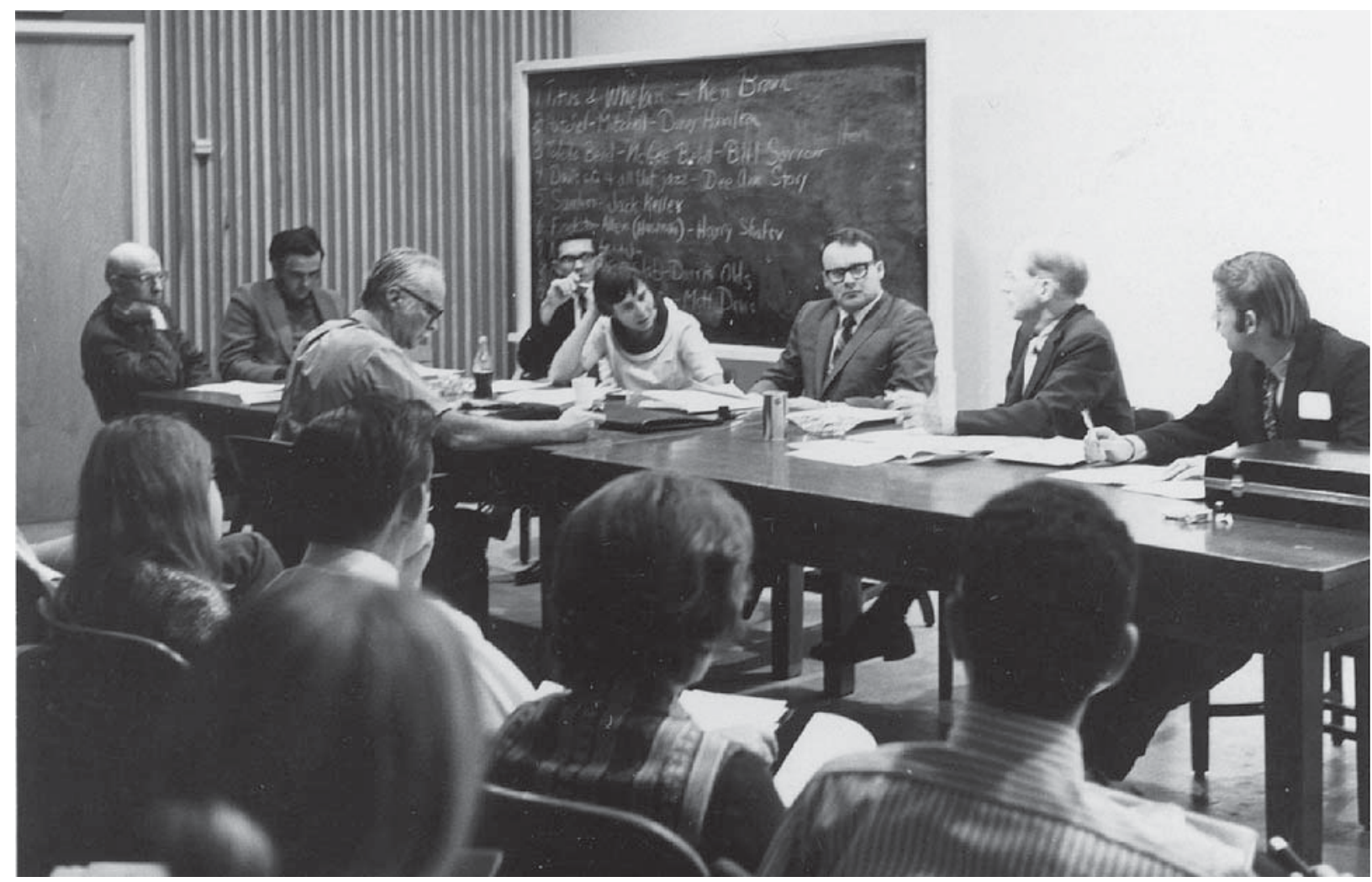

Figure 14. Session at the Thirteenth Caddo Conference. Left to right around table: Mott Davis, Bob Bell, Jim Brown, Don Wyckoff (behind Dee Ann), Dee Ann Story, Frank Schambach, Clarence Webb, Alan Skinner, and the backs of four unidentified people.

For the first time that there is a record, there was a $\$ 2.00$ registration fee; surely such a fee was required before this. Saturday morning, Paul Rossi, Director of the Gilcrease Institute, gave a welcoming address: "A Briefing on the Proposed Gilcrease Institute of American Anthropology." Then seven formal papers were given: Deer Ceremonialism in Early Caddo Culture: The Antler Pile at Crenshaw (Schambach); The Bartholomew Phase: Evidence for the Eastern Boundary of the Caddoan Area (Rolingson); The Functional Anatomy of a Multi-level Mound (Weber; in the file is a copy of Cynthia's paper, with a note from her that says: "Regardless of what the tape says I said, this is what and how I meant to say it"); Certain Caddo Sites in Southwest Arkansas (Soday); Some Flint Types Indigenous to the Caddoan Area (Banks); Tom's Brook: A New, Early (?) Archaic Culture in Arkansas (Schambach); and The John Pearce Site: A San Patrice Tool Assemblage (Webb). The remainder of the day there was a discussion, led by Clarence Webb, on Early Archaic and Paleoindian cultures in the Caddoan Area.

\section{3, Fifteenth Caddo Conference, Natchitoches, Louisiana, March 22-24}

Northwestern State University (NSU) was host again, the meetings being held in the Arts and Science Building. This time, after a couple of one day programs, the Conference was planned for three days (Friday, Saturday, and Sunday, one would guess). The file on this meeting is undoubtedly a preliminary announcement, because there is no complete list of paper titles.

Field reports from the four states were first thing on March 22; then four papers given by Schambach, Shafer, Banks, and Wyckoff. From 3:00 to 5:00 there was a discussion led by Webb on "Content and Extent of Fourche 
Maline." The following day there were papers by Melford Williams, Story, Tanner, Woodall, and Weber; in the afternoon, there were two topics open for discussion, first, "Historic Caddoan Archeology" with Pete Gregory as moderator, then "Caddoan Settlement Patterns and/or New Information on Poverty Point" (perhaps moderated by Webb or Haag but that is not indicated). There was a banquet that evening in the NSU Student Union Building.

Sunday there was a two hour discussion session on Research Problems in the Caddoan Archaeological Area; then the question of topics and when and where the next conference might be (which turned out to be Arkadelphia). There were tours available in the afternoon of some of the historic sites in Natchitoches: Melrose Plantation, Roque House, Lemee House, and perhaps others.

\section{4, Sixteenth Caddo Conference, Arkadelphia, Arkansas, March 23 and 24}

This conference was held at Henderson State College (now University, HSU). Ann Early was now the Survey Archeologist at the Research Station at HSU, and her preliminary program indicates formal papers given on four different topics over the two days. It does not, however, include a Saturday morning session of informal field reports.

Instead, Saturday morning was devoted to five papers on "Resource Procurement and Distribution," as follows: Comparative Analysis of Lithic Material from the Martin-Vincent site (Banks); Novaculite Procurement Patterns in the Eastern Ouachita Mountains (Mike Baker); Lithic Technology at the George C. Davis site (Shafer); Ecological Considerations and Subsistence at the Davis site (John Keller); and Caddoan Trade Material at Cahokia (Mike Fowler, "tentative").

Saturday afternoon there were two topics. First: "Work in Progress," with two papers: Ferguson Site Excavations in the 1973 Season (Schambach); and Post Mid-Ouachita Phase Occupation in the Ouachita River Valley (Early). The second topic was "Pre-Caddoan Cultural Development," with contributions from two archeologists: Pre Caddoan Occupations of the Natchitoches Area (Gregory), and The Late Archaic in the Caddoan Area (Webb).

Sunday was to be devoted, once again, to "Caddoan Chronology" (from 9 Am to whenever): with six people making presentations: 1. Cultural Chronology of Spiro (Brown); Caddoan Unit Concepts and Chronology (T. Prewitt); Carbon 14 Dates for 3CL6 (Hayes Mound) and 3OU22 (Paw Paw site) (Weber); C14 Dates from the George C. Davis site: Summary and Interpretations (Story); C14 Dates from Oklahoma and Arkansas Valley Chronology (Rohrbaugh); and Cahokia Chronology and Caddoan Interaction (John Kelley, Mike Fowler, and others not mentioned).

Those of you who can remember back to 1974 will know what Ann is talking about in the information that went out with the preliminary program: "As of now, there's plenty of gas in Arkadelphia, all flavors, we don't expect it to get any scarcer... If you run out of gas anywhere, or need transportation from Little Rock, we'll arrange a pick up of one sort or another."

\section{5, Seventeenth Caddo Conference, College Station, Texas, March 7 and 8}

There is a preliminary program in my files, indicating that Harry Shafer was the program organizer. Mott's summary indicates there were 10 research reports and two topics for round table discussion: "Caddoan Economic Systems," with Dee Ann Story as moderator and one formal paper by Fullen on Socioeconomic Systems of 
the Orcoquiza of southeast Texas. The second topic was: "Processes of Caddo Evolution," with Mott Davis as moderator and two papers for discussion: A Model of Caddoan Culture History by Schambach, and Improbable

Alternatives to Interaction Sphere by T. Prewitt. The preliminary program indicates 20 minutes were allotted for the research reports, and the intention seems to be that these will be papers read, with accompanying slides, rather than a more informal presentation with handouts as had been done in the past.

\section{6, Eighteenth Caddo Conference, Norman, Oklahoma, March 19-20}

The program, put together by Bob Bell, was held in the Center for Continuing Education, on the University of Oklahoma Campus. For the first time, another room than that in which the meeting would be held was available for people to bring collections for display. "Security will be provided." In addition, there were to be tables for "publications or material for sale or distribution." Finally, Friday evening there was, again for the first time, a "Caddo Indian special program provided by the Whitebead Hasinai Cultural Center."

The agenda as outlined in the preliminary program indicates a different approach to the presentations, as well. Bell had indicated in his first notice that he would like to have a roundtable discussion of Fourche Maline "so that we might have a better understanding as to what is meant, where and when it occurs, how it related to later cultural manifestations, etc.” Those listed as a part of the roundtable are: Bell, Wyckoff, Hoffman, Lopez, Crook, and Neal. This discussion was planned for Friday morning, continuing in the afternoon if necessary. Two other roundtables scheduled for Friday afternoon and on to Saturday morning, if necessary, were to discuss Early Plant Utilization and Caddo Settlement Patterns.

Field or project reports were planned for Saturday afternoon. At the time the tentative program was sent out, Bell reported six papers already received: Possible Late Puebloan Trader's Site in Eastern Collin County, Texas (Crook); The Mounds Plantation, a Coles Creek-Alto Transition (Webb); Fieldwork in DeQueen and Gillham Reservoirs [southwest Arkansas] (Perino); The Plantation Site, Ml-63, eastern Oklahoma (Lopez and Briscoe); The Bruner Site, Hs-74, Haskell County, Oklahoma (Wyckoff); and Recent Field Work at Lake Fork Reservoir, Texas (Bruseth).

\section{7, Nineteenth Caddo Conference, Natchitoches, Louisiana, March 25-27}

Again the conference was held at Northwestern State University, in the Arts and Science Building. The tentative program indicates Friday morning was for current research presentations, but this time it includes papers on more than digging, artifacts, mounds, and cemeteries. For example, Dee Ann Story gave the first paper, which was on "Advantages and Disadvantages of SYMAP." Then we get down to some more traditional reports and papers over Friday and Saturday morning: Possible Early Caddoan Hunting Camps, Atoka County, Oklahoma (D. Hughes); 1976 Field Work at the McCutchan-McLaughlin site, Oklahoma (Hofman); A Systemic Approach to Artifact analysis (Mitchum); Decorated Ceramics from the Deshazo site (Godwin); The Attaway Site: a Late Caddoan Cemetery-Hamlet at Lake Palestine, Texas (Shafer); The Wylie Focus Pit Enigma: A Novel Interpretation of Function (Shafer); Evidence of Violent Death from a Mass Burial at McCutchan-McLaughlin (Rogers); The Current Status of Radiocarbon Dating in the Caddoan Area (M. Davis, Patterson, Valastro, and Varela); Archeological Work within the Proposed Clayton Reservoir, Oklahoma (Bobalik); Soil Development and Channel Morphology at the Gahagan Site, Louisiana (Ryan and Lenzer); Salvage Excavations at the Roden Site, Oklahoma (Perino); Excavations at the Pargoud Landing Site, Ouachita, Louisiana (Greene and Heartfield); Tunican Occupations of the Ouachita Valley (John Duke); French Garrisons of Louisiana, 1699-1769 (Rene Chartrand of Parks Canada); Changing Material Culture of the Hasinai (Russell Magnaghi, Northern Michigan University); and finally an hour long discussion of "Historic Caddoan Archeology, History, and Geography," led by Pete Gregory. 
On Sunday Morning there was an hour for "unfinished business," presumably to allow some time to ask questions of one or more of the presenters. This was followed by a final paper by Charles Hockensmith of the University of Kentucky: "The Steck Site, A Titus Focus Midden, Wood County, Texas." The "business session" likely discussed the possible agenda and place for the next conference. Having said all that, Mott's summary, taken from his notes made at the conference, indicates more field reports: Review of work in Southwest Arkansas-the Hodges collection and a reclassification of Southwest Arkansas pottery (Schambach and Early); the Felsenthal project by the U.S. Army Corps of Engineers and U.S. Fish and Wildlife Service in the Ouachita River in south-central Arkansas (Schambach); Ann Early's report on the Standridge site on the Caddo River, Arkansas; Poverty Point and other matters in Louisiana including threat of Corps of Engineers work along the Red River and of strip mining, by Webb and others; Paleoindian materials, by Bob Neuman; Roden site, by Greg Perino; and Caddo materials at Fatherland by Stu Neitzel . There was also a major discussion (Mott's words) on Friday afternoon, scheduled for two hours on "Research Design and Contract Archeology," chaired by Dee Ann Story. Now, that's a sign of the times.

\section{8, Twentieth Caddo Conference, March 17-18, Nacogdoches, Texas}

Hosted by Jim Corbin and the Anthropology Program at Stephen F. Austin State University, the initial announcement indicates: "Although the Caddo Conference in past years has been somewhat unstructured, it is felt that the conference should also be directed toward more specific problems in the area." Indeed, there are several new aspects to the final program, including that Jim has asked that abstracts be sent to him by February 1. The first change in the presentations was when the initial paper on Friday morning was an hour long one by Mildred Mott Wedel, entitled "Aspects of Bernard de La Harpe's Expedition (1719) to Caddoan Peoples of the Red and Arkansas Rivers."

Then there were "traditional" field/analysis reports: Parris Mound, Phase I Testing (Muto); 1977 Field Work at McCutchan-McLaughlin, Latimer Co., Oklahoma (Wyckoff); Research at the Otter Creek site (HS-25), Haskell Co., Oklahoma (Gettys); Hearth and Disease in a Fourche Maline Population from Eastern Oklahoma (Powell); The Montgomery I Site, A Bossier Period Caddoan Hamlet (Webb and Jeane); Prehistoric Utilization of Igneous Lithic Resources from the Ouachita Mountains (Rolingson); and Distribution and Chronology of Caddoan Mounds in the Arkansas Basin (Wyckoff).

There was also an "informal talk and discussion" first thing Saturday morning, led by Dee Ann Story, on "Importance of the Community as the Building Block in Settlement Pattern Studies." The rest of the morning saw another change to the informal nature of the conference. The time was devoted to a "Hanna Site Symposium," with five papers: Project Goals and Architectural Remains (Thomas); Lithic Analysis (Wright); Faunal Remains (Byrd); Botanical Remains (Shea); and Settlement Patterns (Gregory) (see Thomas et al. 1980), where some of these papers are published, along with a complete report on the excavations and analysis).

After lunch and one paper (Wyckoff's on Caddoan Mounds), Dee Ann gave a "Pre-Field Trip" presentation on the George C. Davis site, and at some time after 2:00 PM, all those who wanted went off for a tour of the site.

\section{9, Twenty-first Caddo Conference, Arkadelphia, Arkansas, March 23-24}

It was Ann Early's turn again to host the conference on the campus of Henderson State University. The "tradition, from last year" of abstracts for all papers was continued and sent or given to all registrants; tables for displays or selling publications were also available, having started at the 1976 meeting in Norman. However, an informal round table "show and tell" discussion of Coles Creek ceramics, harks back to the "good old days." 
Frank Schambach coordinated the session, and had asked people from other states to bring examples of their Coles Creek sherds so that variability could be compared. This session was scheduled for all morning on Friday. The preliminary program says "There will be closed circuit TV monitors for interested persons to listen in on the discussion and see the materials from seats in the audience." However, neither Frank nor Ann remember if this actually occurred, TV monitors and all.

Starting Friday afternoon, and running through Saturday mid-afternoon, there were "Field Reports and Research in Progress." Fourteen 20 minute papers are listed that briefly covered the following topics: Archeomagnetic Dates in Southwest Arkansas (Wolfman); The Tilson Site (Gilmore); Early Historic Hasinai Elites (Wyckoff); Lithic Raw Material Utilization in the Caddoan Area (Perttula); Use of Local Pebbles in Tool Production (Studer); Mound Groups in the Ozarks, Northwest Arkansas (Fritz); 1978 work at Clayton Lake, SE Oklahoma (Lintz, Vehik, and Bobalik); Plaquemine Culture in Louisiana (Neuman); Ceramic and Projectile Point types Common to Coles Creek/Plaquemine and also Bossier Complexes (Webb); Archeological Units and Cultural Chronology in the Wister Valley (Galm); Preliminary Analysis of Burials from the Wister Valley (Earman and Snow); Ceramics from the Williams I site (Oklahoma) (Irvine); The Gold Mine site, northern Louisiana (Helfert); Site Plowing and Systematic Surface Collections at Lake Fork Reservoir (Bruseth); and Pre-Mississippian Painted Pottery in the Lower Mississippi Valley (Belmont).

At the bottom of Ann's initial mail out to the Conference mailing list, she said: "In order for conference participants to continue their informal discussions in a relaxed atmosphere in this dry county, we have reserved a room at the DeGray State Park Lodge for people to bring their own refreshments and have dinner on the evening of March 23." She also cautioned people to get their reservations in ASAP for motel rooms, because the conference was to be held during racing season at Hot Springs and motel space in Arkadelphia would be quickly taken up on the weekends.

\section{0, Twenty-second Caddo Conference, Texarkana, Arkansas, March 27-29}

This was a memorable meeting for several reasons: the sessions were held at the Texarkana Junior College (on the Texas side of the border) but the reception on Thursday evening and the banquet/cocktail party was at the Best Western, Master Host Inn (on the Arkansas side of the border). The sessions started on Thursday instead of Friday; the program included abstracts of all papers (at few earlier meetings abstracts were distributed separately); there was a scheduled cocktail party and banquet; and, most memorable, there was a picnic and tour at, and of, the Crenshaw site after the program on Saturday afternoon.

On Thursday there was a full day symposium by the staff of the Arkansas Archeological Survey, summarizing accomplishments in the 12 years since the Survey was created. This was chaired by Neal Trubowitz and Marvin Jeter (Trubowitz and Jeter 1982). Thursday evening was a reception in the Hospitality suite at the Master Host Inn. "Bring your own beverages. Dinner on your own. (If you like fresh Red River catfish served country style—all you can eat for about $\$ 7$ per person—with draft beer available, try Hamm's at Garland City, Arkansas, which is 20 miles east of Texarkana, on Highway 82.”)

Friday there were topical subjects where either formal papers were read or there was general discussion scheduled for about an hour. General Discussion Session \#1 was on "New Directions in Caddo Archeology," chaired by Don Wyckoff. There was an initial paper by Steve Williams (Harvard University), titled "Caddo Archeology Retrospect and Prospect." Then there were six papers on Recent Work in the Red River Valley: Geomorphology and Paleogeography of the Red River Valley in Arkansas: An Initial Statement (Pearson and Gagliano); Red River Survey in Texas and Oklahoma (Bennett and Gilmore); Preliminary Analysis of the R. 
K. Harrison Lithic Collection from the Crenshaw site (3MI6), Southwest Arkansas (McConnal); Contents of Certain Cemetery Burials at the Haley site (3MI1) (Webb); Spirit Lake site (3LA83) (Hemmings); and Recent field work in Northwest Louisiana (Gregory). Then there were three papers on Spiro Archeology: Preliminary report on 1979 excavations at Spiro (Rogers); Harlan Phase Lithic Technology at Spiro (Heffington); and Is there a Spiro Phase in Arkansas? (James Brown).

The remainder of the day was taken up with four papers on Caddo mounds in East Texas, and then a short discussion on the Fourche Maline Culture (Wyckoff and Baugh). The East Texas mound papers were: Report on Excavations at the McKenzie site (41WD55) (Granberry and Lorrain); Excavations at the Washington Square Mound site, 1979 (Corbin); The Reavely-House Mound, Washington Square Mound site (burial mound stratigraphy and burials) (41NA49) (Corbin); and Cultural Features in the Village area, Washington Square Mound site (Green or Walker).

Friday evening was the cocktail party and banquet at the Master Host Inn, in honor of the retirement of Bob Bell (Figure 15). It was stressed that you could only go to one of these, not both, presumably because of the capacity of the motel to provide space. There is no indication how many people were expected at the conference, but some sketchy notes in my folder indicates there were 42 people at the cocktail party, and 50 at the dinner. A good-sized crowd.

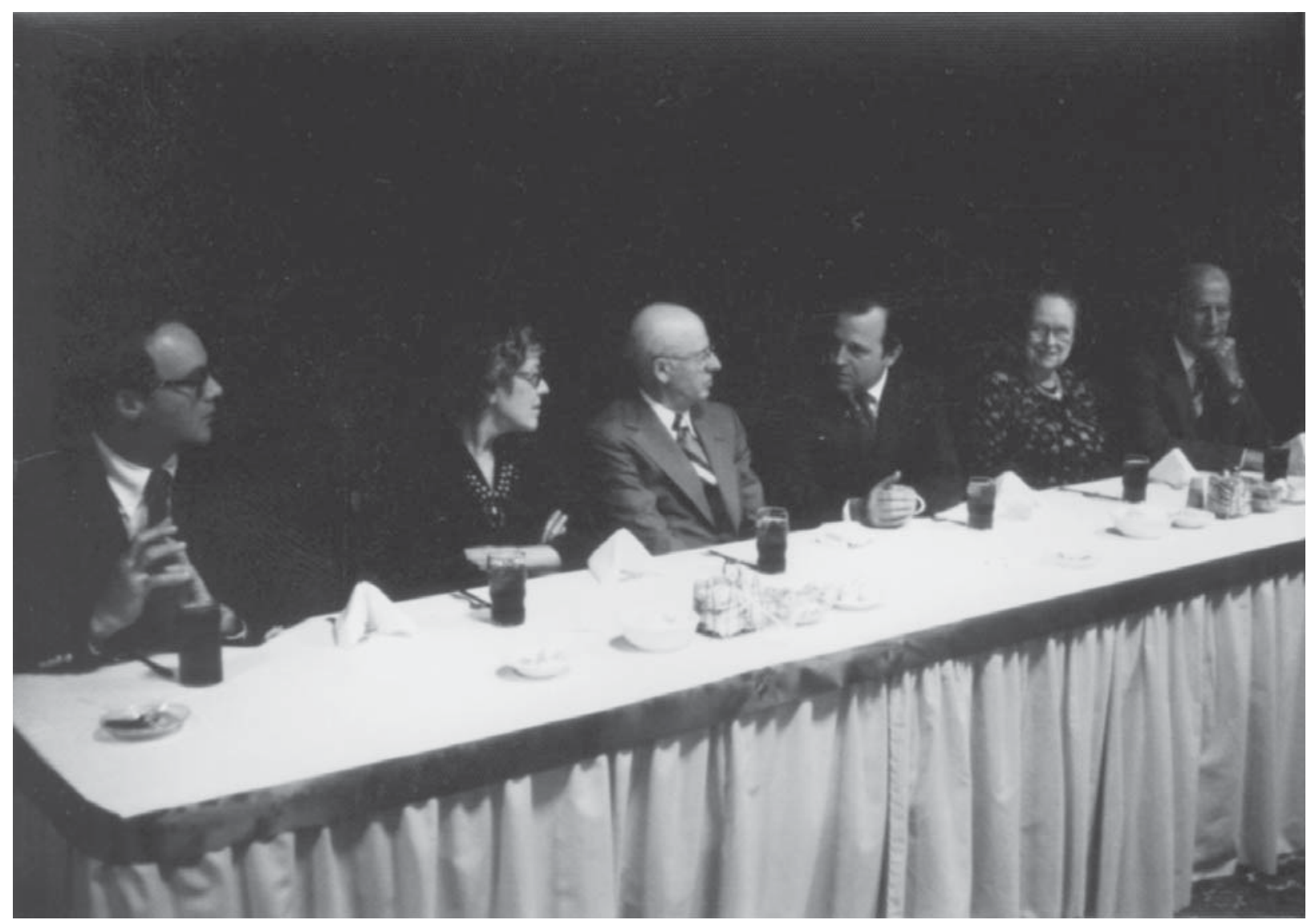

Figure 15. The head table at the banquet honoring Bob Bell upon his retirement. Left to right: Frank Schambach, Virginia Bell, Bob Bell, Steve Williams, Dorothy Webb, and Clarence Webb. 
On Saturday there were more papers, divided into topics or geographical areas, from 9:00 AM to 2:45 PM, with an hour and a half for lunch. The first topic was "Caddo Ethnoarcheology and Ethnohistory," and there were four papers: Early Caddoan Basketry Patterns on Pottery (J. Stoker); Reconstruction of Caddoan Pottery Making Techniques (E. Stoker); Basic Pottery Manufacturing Experiments (Gilmore and Niendorf); and Caddoan Ethnohistory and Historic Archeology: A Record of Change (Perttula).

Two papers were on fieldwork in the Ouachita River valley in Arkansas and one on fieldwork in Oklahoma. These were: Preliminary Report of the 1979 Felsenthal Project, south central Arkansas (Dinnell and Hemmings); The Hampton Phase II Survey, Calhoun County, Arkansas (Lafferty); and 1979 Investigation at Clayton Lake, southeastern Oklahoma (Lintz, Vehik, and Bobalik).

Two more topical sessions filled the afternoon. Two papers were on physical anthropology: Preliminary Analysis of Human Skeletal Remains from the Bug Hill site (34Pu-116) (Vehik, Mayo, and Hood); and Dietary Reconstruction from Observations of Enamel Wear Striations on Caddo and Fourche Maline Molars (Moore-Jansen, Rose, and J. Stewart-Abernathy). One 45 minute session was a discussion of Caddo Ceramic Typology [sound familiar?]: Perino, Webb, and Schambach urged others to present new types or varieties.

At 3:30: "All adjourn to the Crenshaw site for tour and barbeque (pray for a warm clear afternoon—but bring a warm jacket and some shoes that can take a little red mud)." This picnic was put on for us by Dr. and Mrs. R. K. Harrison of Texarkana, and their daughter, Judy, and her husband Larry Head. The Harrison's own half of the large Crenshaw site and maintain a deep interest in the preservation of the site. According to Mott's summary, we all "spent a cool pleasant evening absorbing goat barbeque."

\section{1, Twenty-third Caddo Conference, Norman, Oklahoma, March 12-14}

This meeting was hosted as usual by the staff of the Oklahoma Archeological Survey (OAS). A new addition for others to live up to was provision of a shuttle bus from the Ramada Inn to the Botany-Microbiology Building on the University of Oklahoma campus. Abstracts were not mentioned in the original announcement and none were with the program (Figures 16 and 17).

The meeting was divided into four symposia, and one poster session, also a new addition. This latter, scheduled for an hour, seems to have had two genuine posters, one by Jerry Sullivan of the Texas Parks and Wildlife Department on an Experimental Archeology Program Proposal, and one by Lois Albert of the OAS on a Pollen Profile from Ferndale Bog in Atoka County, Oklahoma.

The remainder of the "poster" session was a show and tell for individuals to view, compare, and argue about lithics and ceramics. Ann Early brought boxes of samples of Arkansas novaculite (Figure 18); Jim Brown brought Coles Creek pottery samples; Don Dickson had Western Ozarks chert samples; and Chris Lintz and Charles Wallis had lithic samples from south central Oklahoma.

Friday morning's session was on "Caddoan Settlement Variability," with seven papers: The 'Caddo Area:' One or Two? (Brown); Caddoan Settlement Variation in the Arkansas Basin (Wyckoff); The Potential of Caddoan Bio-Archaeological Research (A. Mires and Waddell); Setting and Nature of the Battle site and the Great Mound (Hemmings and Schambach); The Cedar Grove site: A Late Caddo Farmstead on the Red River (southwest Arkansas) (Trubowitz); Caddoan Usage of Shelters in the Western Ozarks (Dickson); and Preliminary Excavations at the Huntsville Mound site (3MA22) (Sabo). 


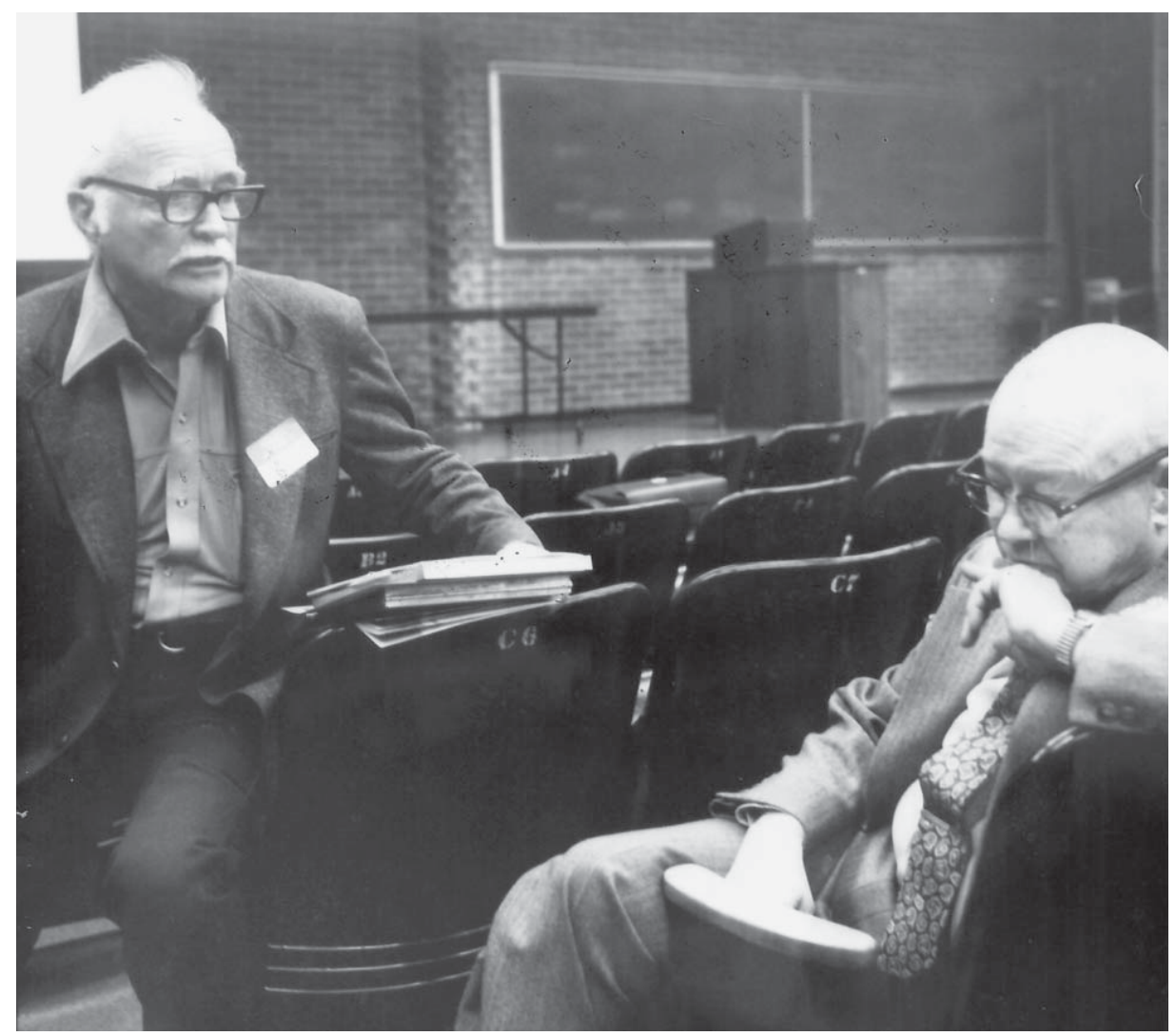

Figure 16. Mott Davis talking with Jimmy Griffin.

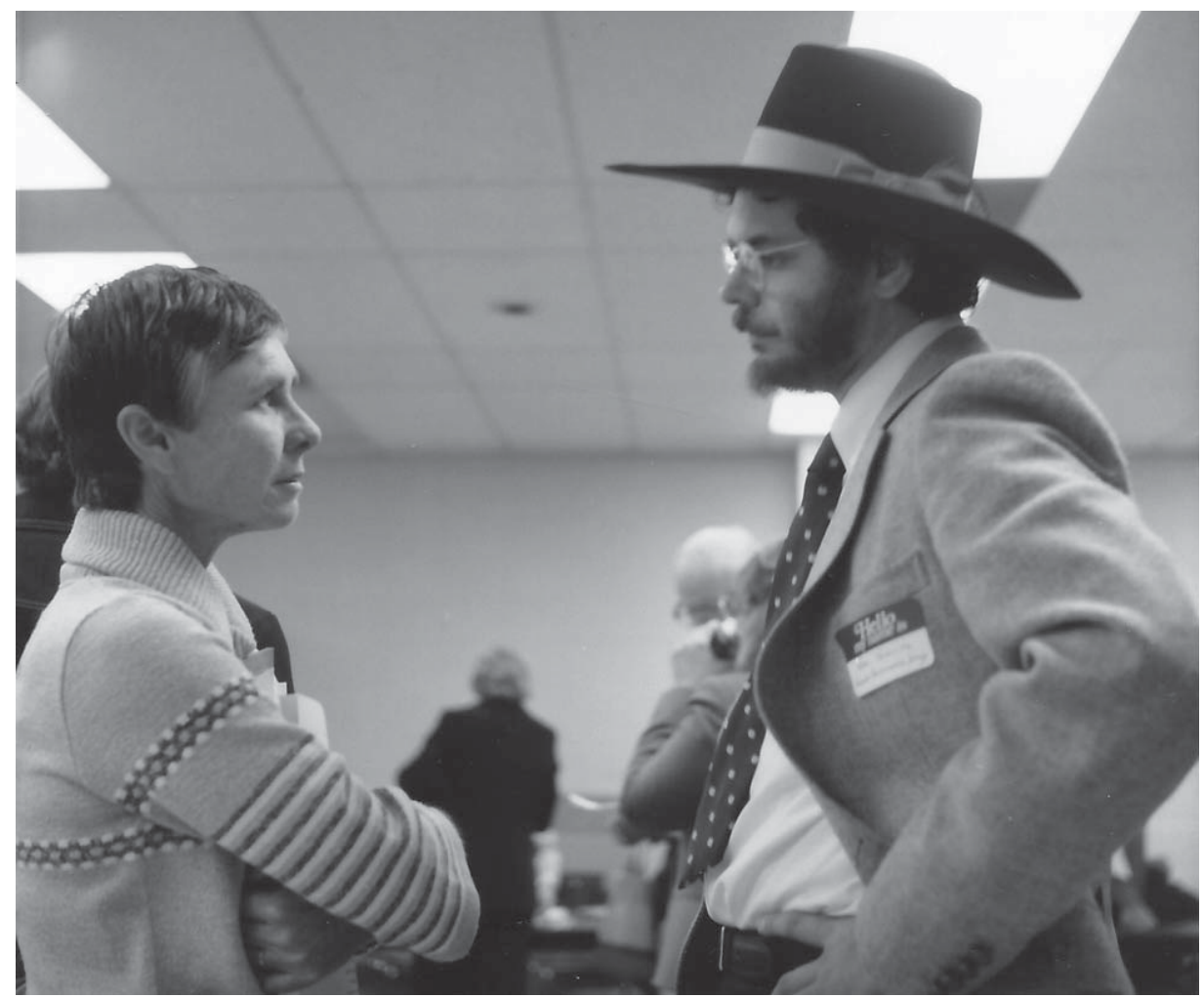

Figure 17. Dee Ann Story and Neal Trubowitz talking at the Twenty-third Caddo Conference. 


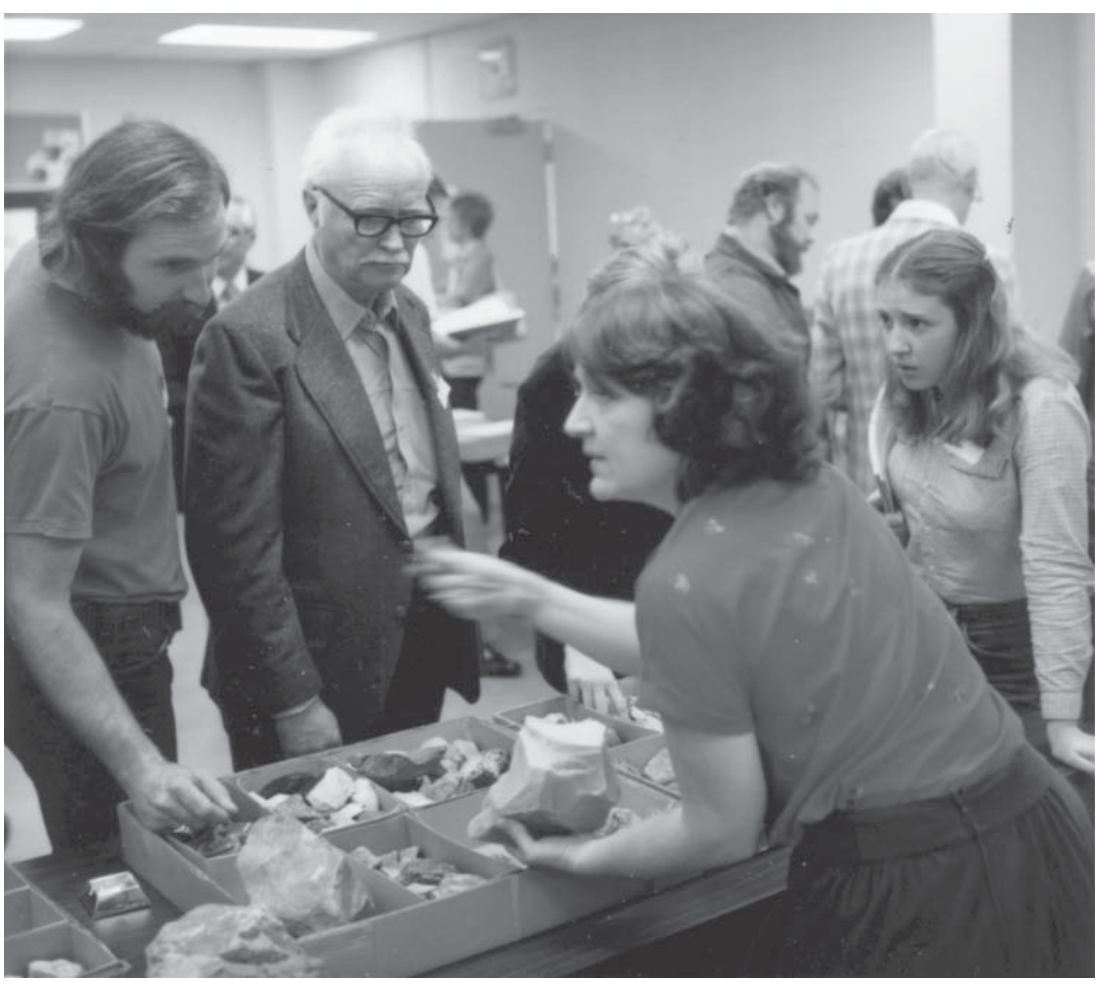

Figure 18. Ann Early with samples of novaculite. Left to right: Andy Cloud, E. Mott Davis, Ann Early, and Marybeth Tomka.

Friday afternoon was a symposium on "Caddoan Exchange Networks" with three papers: The Arkansas River Quapaw Phase-Caddoan Exchange (Hoffman); Possible Caddoan Trade Vessels in the University of Arkansas Museum from Carden Bottom (Clancy); and Caddoan, Plains, and Southwestern Exchange Networks (Swenson and Baugh).

Friday evening, there was not only a banquet, but a banquet speaker. Jimmy Griffin was invited back to the conference and gave a talk on a subject not brought up at the conference since Krieger left for California: "Mesoamerican Influences in the Southeastern United States."

Saturday morning's symposium was on "Studies of Caddoan Material Culture: Lithics, Pottery and Other Remains," with five papers: Favored Lithic Resources and Changing Knapping Strategies in the Arkansas Basin (Wyckoff); Silicified Wood Fracture Properties and Reduction Strategies (Girard); Experimental Ceramics (Gilmore); Southeastern Pine Bark Pottery Firing Techniques (E. Stoker); and Nineteenth and Twentieth Century Caddo Artifacts and Their Possible Origin (J. Stoker).

The final session was on "Current Research" with eight papers: The Conley site, presumably Middle Archaic (Webb); The Washington Square Mound site, 1980 (Corbin); Ceramics from the 1980 Test Excavations at the Cedar Grove site, A Caddo V Component in the Great Bend Region, Arkansas (Schambach); Geomorphology of the Red River, Red River Project, Phase II, Settlement Model Testing (Gilmore, McCormick, and Jacobs); Review of 34Lt-54 (the Runner site in Wister Reservoir, A Midden Site in Southeastern Oklahoma) (Pennella, Heffington, and Haines); Correlations of WPA Excavated Material to Village Houses at Spiro (Heffington); and Current Research at Spiro Mounds site (Rogers). 


\section{2, Twenty-fourth Caddo Conference, Fayetteville, March 19-20}

The conference sessions were held at the University of Arkansas Continuing Education Center (with a Hilton Inn attached), on the historic Fayetteville town square. Mike Hoffman was program chair and he was able to brow-beat people to send in abstracts so that 13 pages of them were available to registrants at the beginning of the conference. Early Thursday evening there was Open House from 6:00 to 8:00 PM for visiting and registration at the headquarters of the Arkansas Archeological Survey, and then a First Night party "at Fayetteville's famous Hoffrichter House, Keg provided." From late Friday afternoon on there was an Open House in a reserved room of the Old Post Office, which was situated in the middle of the square just across the street from the Continuing Education building. Jerry Rose also opened his Bioarchaeology Lab on the Campus on Friday evening for visitors.

The scientific portion of the meeting on Friday and Saturday was divided into Theme Sessions. For each one, there was a chair, who introduced the topic with a 30+ minute presentation. The research papers were then restricted in the first session to 10 minutes; other sessions gave 15 or 20 minutes for presentations.

Friday morning's Theme Session was on "The Caddoan Area in the North," with Jim Brown as chair. Papers were as follows: Climatic Change and the Origins of Arkansas Basin Caddoans: A Cross Timbers Perspective (Reid); Preliminary Results of Regression Analysis on Harlan Phase Burial Goods (Peterson); Social Ranking in the Harlan and Spiro Phases (Rogers); Plaza Excavations at Spiro (Moore); Structural Features in Mound A at the Huntsville site (3MA22) (Sabo); A Tentative Settlement Pattern of the Late Prehistoric Period, Madison County, Arkansas (Collier); Preliminary Analysis of the Turner Cave site (Vogele); Late Prehistoric Deer Hunting at the Albertson site (Barnett); and The Point Remove Site: An Introduction (A. Duncan).

Theme two on Friday afternoon was "Caddo Bioarchaeology," organized and chaired by Jerry Rose. The papers were: Diet and Dentition in Caddo Bioarchaeology (a proposed dietary model) (Moore-Jansen); A Biocultural Study of Cranial Deformation as Practiced by the Caddo Indians (Loveland and Loveland); Agriculture and the Fourche Maline-Caddo Transition (Rose); Regional Variation of Human Adaptation in the Caddo Area (A. Mires); Changing Social Organization in the Arkansas Valley, Spiro and Fort Coffee Phases (Rohrbaugh); and Caddoan Adaptive Efficiency: A Paleoepidemiological Model (Powell). Jane Buikstra provided the Summary and Conclusions.

There were three Saturday morning sessions, the first being: "Perspectives on Chronology in the Caddoan Area," with Don Wyckoff as chair. There were four papers: The Chronological Sequence at the McCutchanMcLaughlin site, 34Lt-11 (Baugh); Radiometric Chronology of the Huntsville Mounds Site, 3MA22 (Kay); Late Chronology of the Spiro Locality, Spiro and Fort Coffee Phases (Rohrbaugh); and Tree-Ring Chronology Development in the South Central United States and the Potential for Archeological Tree-Ring Dating in the Caddoan area (Stahle).

The second Theme Session was: "Lithics in the Caddoan Area," chaired by Don Dickson. Papers were: Late Woodland Manufacturing Processes at the Toltec site (T. Hoffman); and Source Areas for Exotic Lithics at the George C. Davis site (Shafer).

The third session was Research Reports I (with no chair): Functional Analysis of Caddoan Ceramics: Procedure and Detail (Taylor and Christiansen); Reconstruction of a Caddo House (Cheatham and Young); Synopsis of the Prehistory of Jackfork Valley, Southeast Oklahoma (Vehik); and An Arkansas Spiro? The Research Potential of the Bowman site (M. Hoffman). 
Saturday afternoon was full of Research Reports (II) with 11 papers: The Effective Environment of Caddo Settlement of the Prairie Margin: New Soils and Pollen Data from the Richland Creek Project, North Central Texas (Raab); Big Rock: A Stratified Woodland and Caddoan Rock-Shelter on the Southwestern Periphery (Guderjan); Evidence of Caddo Influence in North Central Texas: Site Data from the Richland Creek Project (Irvine); New Discoveries Concerning the Wylie Focus Pits of North Texas (Raab); Archeological Investigation at the Washington Square Mound, 1981: A Lesson in Humility (Corbin); Archeological Investigations at the Reavely-House Mound (McDonald); The Ceramics of Washington Square Mound site (Hart); Research Progress on the Cedar Grove site (Trubowitz); The Ceramic Assemblage at the Cedar Grove site: A Component of the Caddo V Period Chakanina Phase in the Great Bend Region (Schambach and Miller); The East Site Revisited (Early); and The Washington Site Revisited (Miller).

There was a "business meeting" right after lunch on Friday. Mott's notes summarize the discussion: "The growth of the Conference over the years, from small and informal to large and formal, was deplored. How is the conference to be kept from becoming even more formalized? We certainly don't want concurrent sessions!"

\section{3, Twenty-fifth Caddo Conference, Natchitoches, Louisiana, March 11-13}

There is a purple mimeographed program in my file, which seems to be a preliminary one, but, once again and finally, Mott's notes provide some clue for what went on. The meeting was held on the campus of Northwestern State University, as usual, with Pete Gregory as program chair. Friday evening (if it was Friday?) there was an Open House at the Tante Huppé Prudhomme House, courtesy of Robert DeBlieux, Louisiana's State Historic Preservation Office, and Ann Jones, Director of the State Division of Historic Preservation. Saturday night there was a Creole Supper put on by the St. Augustine Church women's organization, followed by a party at Pete Gregory's house.

Friday morning started with a two hour session, of eight papers and two discussants, on "Caddoan Investigation in Northwestern Arkansas: New Data and Prospects." (Most papers are derived from the Ozark-St. Francis National Forest Project. The Wedington Unit is a specific area of the western portion of the Ozark National Forest, near the Oklahoma border.) The papers were: The Watt's Farm Site, 3WA6, and the Mystery of Caddoan Culture in the Western Ozarks (M. Hoffman and Cherry); Caddoan Investigations in Northwest Arkansas (Kay); Wedington Survey: Field Methodology (Zahn); Vegetation Reconstruction of the Wedington Unit using GLO data (Vogele); Wedington Unit Topography and Biophysical Setting (Sands); Wedington Unit Empirical Archaeological Site Distribution (McKelway); Wedington Unit Computer Simulation Survey of Site Distribution (King); and Assessment of Wedington Survey Results (L. Ayers); Jim Brown and Frank Schambach were the discussants.

Right before lunch, an hour was devoted to "Reminiscences of Conferences Past: The Halcyon Days of Caddoan Archeology," arranged by Bob Neuman. Those contributing to this discussion were Mott Davis, Alex Krieger, Bob Bell, Phil Newkumet, and Sam Dickinson (in a paper read by Hester Davis; see Dickinson 1991).

The remainder of the day contained a series of miscellaneous reports. In order as they were listed on the preliminary program: An Overview of Cedar Grove: Culture and Land Use 1670-1982 (Trubowitz); 1982 Excavations of Brown and Copple Mounds of the Spiro Mounds Group (Peterson); X-Radiography of Spiro Artifacts (P. Hoffman, Riddick, and Cherry); Some Statistical Aspects of Post Hole diameters at the George C. Davis Site (Ernest); Caddoan Trade Networks (R. Vogel, University of Minnesota); and Naming the Types: A "Hands On" Session on Projectile Point taxonomy (Perino). 
Saturday morning the first two hour session was a Symposium: "Beyond Pots and Bones: A Look at Caddoan Social Organization," organized by Michael Nassaney. (Here I come upon my first big problem: Mott's notes on these papers do not fit well with the list on the mimeographed sheet in the file, which may well be the preliminary program. I'm going to assume that the difference is that some people listed did not make it to the conference, and that Mott's list is what was actually presented.): Current State of the Art in Inferring Social Organization (Nassaney); Ethnohistoric Evidence concerning Caddo Social Organization (T. Hoffman, read by M. Hoffman); Contrasts in Mortuary Behavior Between the Arkansas River and Red River Valleys (Zahn); Ecological Model of Caddoan Settlement and Social Development (Nassaney); and Testing the Model Against Demographic and Osteological Evidence (A. Mires). Discussants were Jim Brown and Ann Early.

There was a round table discussion organized by Pete Gregory entitled: "Caddoan Studies: From the Caddo Point of View." The discussants were Phil Newkumet, Claude Medford, Jr., Charlene Hodge (Caddo), and Mary Burnett (Caddo).

FINALLY, at some unrecorded time during this meeting, the conference acted as if it were a real, formal, organized entity! Hester Davis announced the creation of the Clarence H. Webb Award for Outstanding Contributions to Caddoan Archaeology. The first presentation of the Award was made to Clarence himself. The archives on this award are buried deep in my stored files in the Arkansas Archeological Survey building, but my memory is this: at the next meeting (1984), three awards were presented: to Dee Ann (Suhm) Story, Alex Krieger, and Ed Jelks for the publication of their Introductory Handbook of Texas Archeology. The fifth award was made to Bob Bell, probably at the Norman meeting in 1985. We then skipped to 1989, when the award was given to Mott Davis (since I was involved in the creation of the award, this seems to be nepotism at its best). There is a picture in the $50^{\text {th }}$ Caddo Conference: A Retrospective, of Ed Jelks presenting the Award to Mott, which I submit as proof (Figure 19). Since then no award has been presented, not because there are not individuals worthy of this recognition, but, we might assume, because no one has remembered in time to get the award printed and framed!

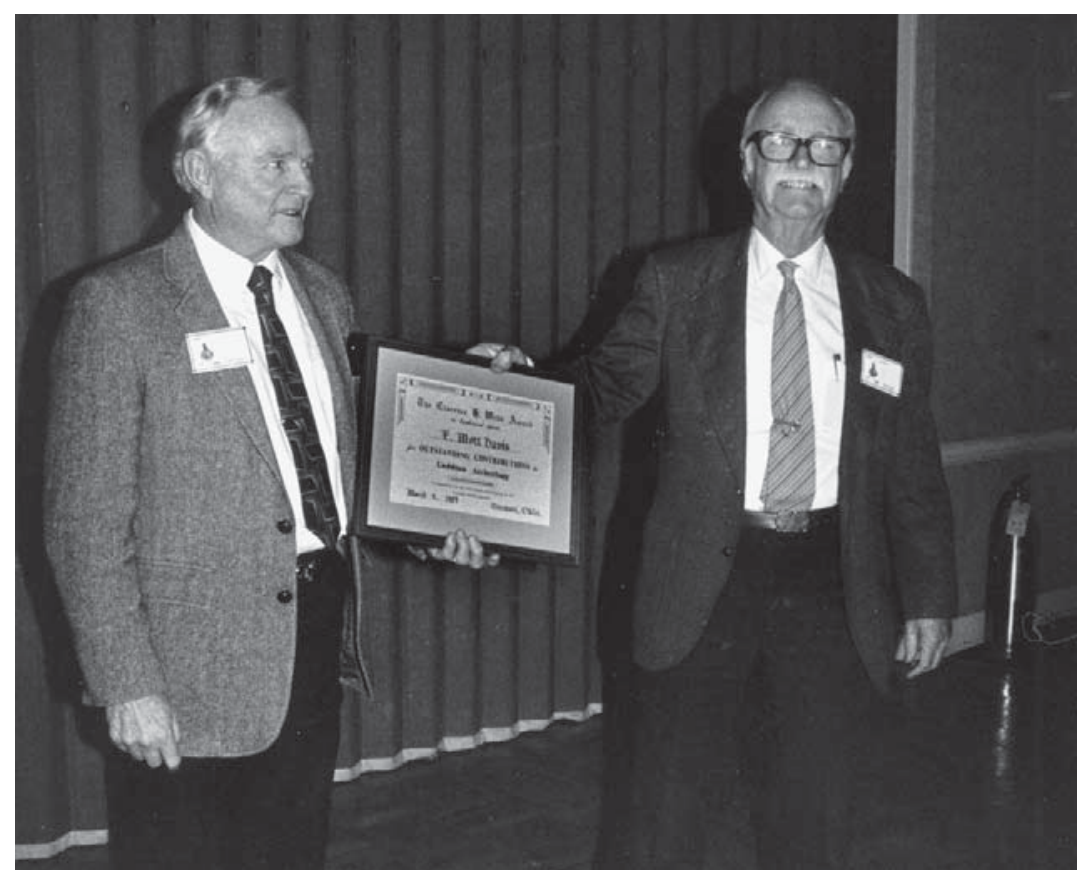

Figure 19. Ed Jelks presenting Mott Davis with the Clarence H. Webb Award at the 1989 Caddo Conference. 


\section{PART II \\ THE CONFERENCES, 1984-2008}

\section{Hester A. Davis}

The second 25 years of papers, symposia, research reports, coffee breaks, tours, and gatherings at Caddo Conferences to watch and eventually participate in Caddo dancing in the evenings, is in some ways much the same as the previous 20 or so, with a few special events and changes in the normal conference settings. The programs, however, also reflect that Caddo archeologists have been keeping pace with what is going on in the world of cultural resource management. Current research reports indicate a growing effort to apply interdisciplinary studies, particularly in the field of bioarcheology. In addition there is an increase in Caddo participation in the programs.

I am not going to list every paper as I did for the earlier conferences. Instead, I will attempt to summarize each conference, while pointing out new and/or unusual aspects to consider for future conferences. Abstracts have continued for every conference, either provided separately to each participant when the meeting started, or more often printed as part of the program. The Silent Auction periodically appears, but is not annually used to raise money to help pay the expenses of the Conference and/or the expenses of the Caddo dancers and drummers to come to the meeting.

\section{4, Twenty-sixth Conference, Nacogdoches, Texas, March 9-11}

Tim Perttula chaired a morning symposium entitled "Woodland and Caddoan Utilization of the Ouachita Mountains," with seven papers. The afternoon was taken up with nine current research papers, with representatives from all four states in the Caddoan area. This segued into an Old Nacogdoches Tamale Supper hosted by the Moral Community, and a party at the Tol Barett House, hosted by Captain and Mrs. Charles Phillips.

Saturday morning there were still four Current Research papers, two from Texas and one each from Oklahoma and Louisiana. The rest of the morning was taken up with a "very informal" symposium on "Experiments and Analysis of Caddoan Technology," chaired by Jim Corbin. Those participating were Carolyn Spears, Lorraine Heartfield, Pete Gregory, Claude Medford, and Kathleen Gilmore. The program does not indicate which technology was represented by which person: I leave you with the challenge of figuring this out.

After lunch the afternoon was spent traveling first to the George C. Davis site and museum, and then to the Washington Square Mound site. For those hearty enough to survive this schedule, there was an unidentified "party" in the evening, with the "business meeting" at 9:00 AM Sunday morning.

\section{5, Twenty-seventh Caddo Conference, Norman, Oklahoma, March 15-16}

The Caddo Tribe of Oklahoma, the Oklahoma Archeological Survey, and the Stovall Museum sponsored this meeting. Saturday morning had the usual mixture of Current Research papers, three from Texas, one from Louisiana, and two from Oklahoma, including the first report on the Grobin Davis Mound Group. In the afternoon, six papers were given on the subject of "Late Prehistory in the Western Ozark Highlands"-five on Northwest Arkansas and one on Southwest Missouri. Two more papers were indicated as an "Update on Pottery Studies."

The evening was spent at a reception at the Stovall Museum, with drinks, finger food, and entertainment by "The Friends of Tradition" (Irish and Appalachian folk music) (What a great idea!). 
Saturday morning was devoted, for the majority of the participants, to seven papers on Current Research on various aspects of work in Oklahoma, ending about 11:30 AM. People were then offered the alternative of driving the 70+ miles to Binger, or take a chartered bus. At 2 PM, everyone gathered for a meal, and then the dancing began (see Figure 1).

Meanwhile, a select few had gone to Binger first thing in the morning to present a two hour program on Caddo Heritage — at the request of the Caddo. Don Wyckoff indicated as early as September 1984 that "the Caddo would like to have 3-5 specialists come to their tribal center and give short (15-20 min) lay-oriented presentations on Caddo prehistory, cultural development, crafts, etc., that really bring out what we believe to be significant about this heritage." Don recruited the following people for the program:

$\begin{array}{ll}\text { 10 AM } & \text { The Caddo Language, Dr. Wallace Chafe } \\ \text { 10:20 AM } & \text { Caddo Prehistory in the Arkansas Basin, Dr. Charles Rohrbaugh } \\ \text { 10:40 AM } & \text { Caddo Prehistory in the Red River Basin, Dr. Ann Early } \\ \text { 11:00 AM } & \text { Caddo Prehistory in East Texas, Dr. Dee Ann Story } \\ \text { 11:20 AM } & \text { Caddo Pottery Technology, John Miller } \\ \text { 11:40 AM } & \text { Caddo History in Louisiana, Dr. Pete Gregory } \\ \text { 12:00 PM } & \text { Summary Perspective, Hester Davis } \\ \text { 12.20 PM } & \text { Potential Cooperation Projects, Tribal Chairman, Henry Shemayme }\end{array}$

In the Oklahoma Archeological Survey's folder for this meeting is a letter from Jim Corbin to Don Wyckoff, indicating that he, Jim, was sending the "up-dated" mailing list and "\$800 of Caddo Conference money." Obviously sometime previously registration fees had been instituted, although in my files up to this conference only once do I have the registration form, indicating a $\$ 7.50$ registration fee. This method of sending the mailing list and accumulated monies on to the next host of the conference seems to have been normal practice-and probably still is.

\section{6, Twenty-eighth Caddo Conference, Little Rock, Arkansas, March 13-15}

The Arkansas Archeological Survey was host for this conference, and Frank Schambach, the program chair, received a grant from the Arkansas Humanities Council to bring in Charles Hudson to give a public lecture on Thursday evening entitled "Hernando De Soto in $16^{\text {th }}$ century Arkansas," and Hudson gave another talk on Friday entitled "Hernando De Soto in the Caddo Area." Hudson's study of the entrada took De Soto on a very different route through Arkansas, after he left the Mississippian villages in the northeast part of the state, than the trail presented by Swanton (1939), almost 50 years earlier. Also for the first time, Mark Michel of The Archaeological Conservancy gave a presentation on the Conservancy's "Caddo Mounds Preservation Program." Although there is no "business meeting" scheduled on the formal program, the Conference voted to contribute money to the Conservancy's efforts to purchase the Grobin Davis site in Southeast Oklahoma. Michel called it "the best preserved remaining civic-ceremonial complex of the prehistoric Caddoan culture."

The traditional Current Research papers took up the rest of Friday and included two on bioarcheology, one on salt-making, several on the protohistoric and/or the early historic period, and one on the computerization of records in Arkansas. Participants were able to recover at a reception and catfish dinner at the conference hotel that evening. 
Saturday morning saw the presentation of a symposium entitled: "History and Prehistory of the Ouachita River Valley," with seven papers, all concerning sites in the Arkansas portion of the valley. Saturday afternoon participants were treated to guided tours of Toltec Mounds State Park.

\section{7, Twenty-ninth Caddo Conference, Bossier City, Louisiana, March 13-15}

In the course of the two full days of this meeting, 16 papers were presented, and there was one symposium and one "round-table" discussion. Friday morning there were five presentations, from a study of the provenience of red slipped pottery defined by petrographic methods, to an update on the Archeological Conservancy. Friday afternoon was taken up by the round table discussion (actually the audience was involved) on the topic of "Pothunting in the Caddoan Area," being lead by the four State Archeologists, five Regional Specialists, four more who had been around long enough to give an historical perspective, and representatives from four tribal groups. The need for discussion was indicated in the abstract: "Because of depressed economic conditions in the region and increased market values for pots and other grave goods, the intensity of pothunting is probably at an all time high.' I don't recall that we solved this problem, but it was a spirited discussion trying to reach some agreement on reality under the circumstances. It was only four years after this that Arkansas' unmarked graves protection act was passed, not, however, instigated by professional archeologists but by Native Americans.

The Saturday morning there was a two hour symposium about "Non-Caddoan Indian Archeology on the Red River" and papers touched upon historic burials, an Apalachee village, Coushatta ceramics, Choctaw settlements, and a Coushatta village. There were two more papers, one on protohistoric ceramics in northeast Louisiana sites, and one on the Paleoindian and Archaic settlement in the Ouachita River Valley in Arkansas. There were nine papers on current research Saturday afternoon.

Entertainment at this meeting was provided Friday evening by a wine and cheese reception hosted by the Northwest Chapter of the Louisiana Archaeological Society, and the Louisiana State Exhibit Museum. Saturday evening there was a reception "portside" at the Holiday Inn (the conference hotel), hosted by Tyson Foods, with "free beer and a cash bar."

\section{8, Thirtieth Caddo Conference, Dallas, Texas, March 10-13}

This was a full two and a half day meeting, not counting the opportunity to register on Thursday evening, the $10^{\text {th }}$. The meeting was hosted by the Dallas Archaeological Society, Geo-Marine, Inc., and North Texas State University. Friday morning there were five Current Research papers. Friday afternoon was devoted to a symposium entitled "Sulphur River Archaeology, Northeast Texas." Eight people were involved but no titles to the presentations are given in the program. A reception was held that evening at the conference hotel (Figure 20).

Saturday morning there were five papers presented, four on current research and one by Roscoe Shemayme of the Caddo Tribe on "Preserving Our Culture Heritage." Saturday afternoon was devoted to another symposium, this one on "Caddoan Archeology: Its Present Status and Future Directions," with 10 participants listed, but no titles of papers. Saturday evening Ruth Ann Ericson offered her home as the scene of a party hosted by the Dallas Archaeological Society.

There were four papers scheduled for Sunday morning, three of which pertained to historic or ethnohistoric studies. The final paper, with the title "the Origins of the Caddo," was presented by Alex Krieger, only his second visit to a Caddo Conference since 1956, when he left for California. Unfortunately there is no abstract for 


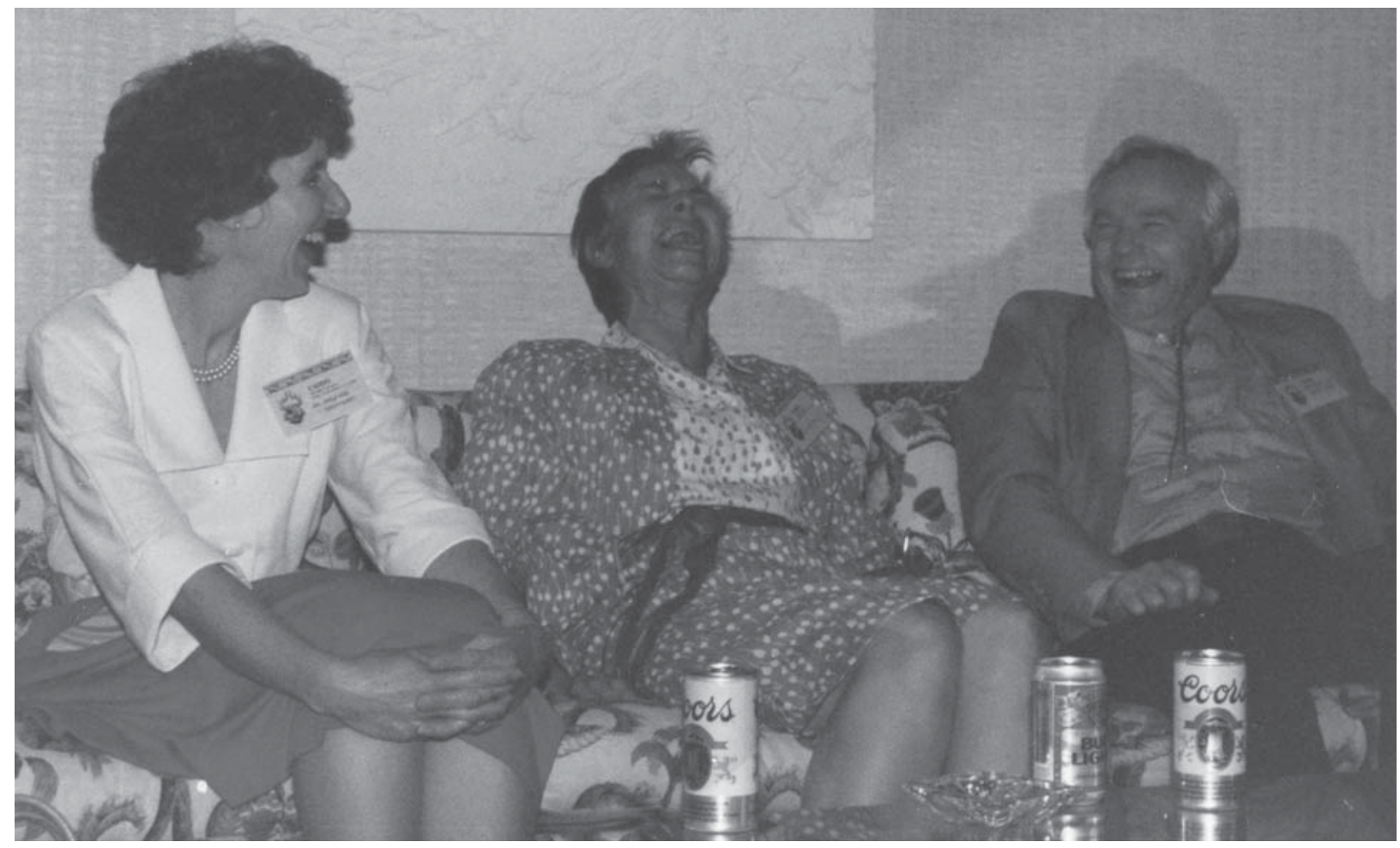

Figure 20. Martha Rolingson, Dee Ann Story, and Ed Jelks (Ed and Dee Ann were telling Krieger stories).

this talk. [I note that the last four conference programs indicated there was an opportunity for selling books, but not for the Silent Auction.]

\section{9, Thirty-first Caddo Conference, Norman, Oklahoma, March 3-5}

A symposium was scheduled first on Friday morning, entitled: "Woodland Manifestations and Caddo Culture." Again there were five participants listed but no paper titles. After a coffee break, Margaret Guccione, a geologist at the University of Arkansas who has worked extensively with archeologists, gave a paper which was of interest to a good many researchers: "Use of Overbank Sediment to Locate the Channel Position During Human Occupation of a Flood Plain.”

Friday afternoon was devoted to seven research reports on ethnohistory, a session chaired by George Sabo. In the evening there was an open house at the Oklahoma Archeological Survey offices.

Saturday morning the ethnohistory papers continued with three more filling the time until the mid-morning coffee break. For the rest of the day there were field reports, a few on Spiro matters, with a total of 10 papers (Figure 21).

Saturday evening there was a banquet, with Mott Davis as the speaker. The title of his talk was "Caddo Conference Memories: Thoughts and Inspirations" [Unfortunately, I do not remember coming across this paper when I helped clean out his office at home and at TARL.]

Five more field reports were given on Sunday morning, ending with "A Report on Reorganization of the Caddo Conference." [REORGANIZATION??] The indication is that Bob Brooks, Hester Davis, Jim Bruseth, and David 


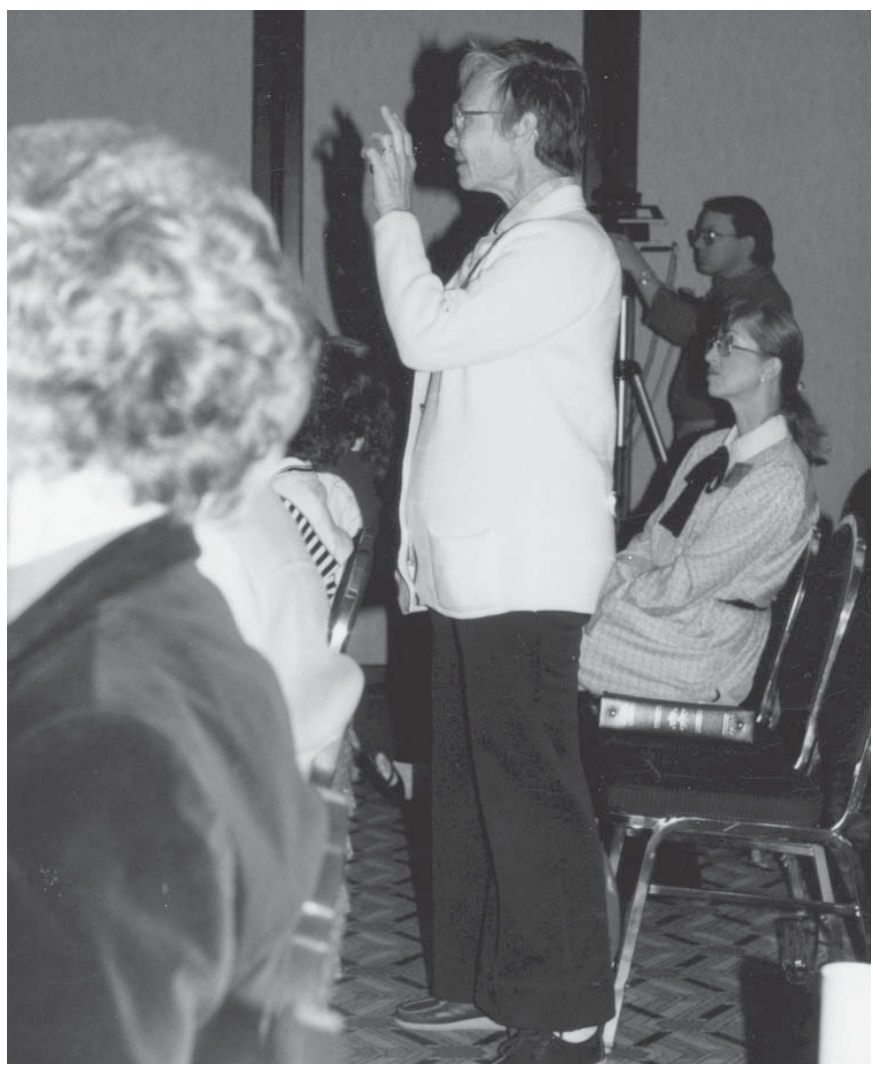

Figure 21. Dee Ann Story and Lois Albert (seated) at the 1989 Caddo Conference.

Jeane/Pete Gregory represented their respective states in a discussion. The nature of the discussion has largely trickled from our memories, but there is a consensus that we wanted to continue the informality of the Caddo Conference, no membership fees, no officers, and no dues. We thought it would be possible to have more thematic round table discussions, lead by a few around a table presenting prepared statements on the topic, and then opening the floor for comments, and more discussion. And the same for symposia on interdisciplinary topics.

However, Tim Perttula had been encouraging the idea of a Caddo Archeology Newsletter prior to this discussion, and he may have brought it up again. If he did, it brought no support from the conference. The result was, however, that Tim started the newsletter in 1989 without any outside support. In 1993, Lois took over as editor and remained in that position for 10 years, at which time (2002) Tim took over again, now in its reincarnation as the Caddo Archeology Journal, which you hold in your hand as you read! It is paid for by subscriptions only. On at least two occasions Tim suggested that the Conference could increase the registration fee and thereby provide some subvention for the Journal or take the plunge and create a more formal organization like the Southeastern Archaeological Conference or the Plains Anthropological Conference-but the time for that has not arrived, if it ever will.

What everyone who attended this conference will remember, however, is waking up on Sunday morning to find that the predicted snow storm - actually a blizzard — was upon us. There was one car of us from the Arkansas Archeological Survey, and we took off east to get on to Interstate 40 at Oklahoma City and drive east, while others did the same for Interstate 35, going either north or south. Another vehicle from Fayetteville followed us once we got on the interstate. George Sabo was driving the state vehicle-he was elected because he is from 
Michigan and had driven in this kind of weather. There were times when both lanes going east stopped for 15-20 minutes or more because 18 wheelers were not able to get traction on even low rises, or because they were stuck on the off ramps. As the day wore on, we realized that we would probably not be able to make it over the Boston Mountains which are between Fort Smith and Fayetteville, so we finally got off the highway at Stillwell, Oklahoma, and got the last two motel rooms in town. Others have similar stories to tell.

\section{0, Thirty-second Caddo Conference, Natchitoches, Louisiana, February 23-25}

The look of this conference's program is different. All but one of Friday's papers, of which there were 10, were given a half hour spot. The abstract for each paper is provided under the paper's title. There are no symposia or panel discussions. There was a tour of the Wells Home at 4:30, and a 7:30 party at the Holiday Inn.

Saturday, the first three papers were on symbolic elements in Caddo culture. Then there are five papers on historic research; one 15 minute presentation on an Arkansas Indian Exhibit in Little Rock; four more half hour presentations on current research in Texas and Oklahoma; two 10 minute papers by Jim Corbin on the Mast site in Nacogdoches, Texas; two papers on upland sites; a 20 minute paper on primary sources for ethnohistoric research on the Caddo in Louisiana, and a 10 minute discussion by George Odell on the Lasley Vore site (an historic contact site on the Arkansas River) in eastern Oklahoma. One more paper was on regional lithic technology focusing on the Gary point; and finally there was a video about research in the Lee Creek valley in western Arkansas.

Sunday morning there was an attempt to allow discussion with no formal papers or presentations, just suggested topics as follows:

10 AM: Call for Regional Reports: Arkansas, Louisiana, Oklahoma, and Texas

10:30: Open Discussion: Non-Caddoan Occupations in the Caddo Area

11:00: Open discussion: The Reburial Issue

11:30: Business Meeting

In my file also is a copy of Clarence Webb's response to what must have been a birthday card signed by many people at the conference (Figure 22). Clarence died in January 1991 at the age of 89 (see Gibson and Gregory 1992).

\section{1, Thirty-third Caddo Conference, Nacogdoches, Texas, March 22-24}

On Thursday, March 21, a three hour evening session was scheduled for an Open Meeting on the Northeast Texas Archeological Plan. This plan was developed by the Texas Historical Commission to guide archeological research in this part of the Caddo area (Kenmotsu and Perttula 1993).

Friday morning's session began at 9 AM (as was usual after coffee, donuts, and an opportunity to look at books for sale from various institutions and presses). The first item on the agenda was a recognition of the deaths of Jonathan Davis (Mott Davis' son) and of Clarence Webb. Although Clarence had not been active in the past few years, his loss was a great one for Caddo archeology (see Gibson and Gregory 1992).

"Regional Research Notes" followed, with 20 minute presentations of five papers. After lunch, a symposium was scheduled, moderated by Tim Perttula, entitled "What is CADDO?" There were opening comments, then "papers" by Frank Schambach and Jim Brown, known to have very different views of Caddo in the "heartland" 


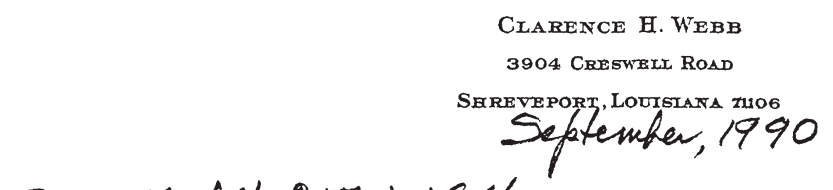

Dear Kinfolts om Erind falks:

The wise hittle owls of Porenty Point gare me a message

and epare it on to you:

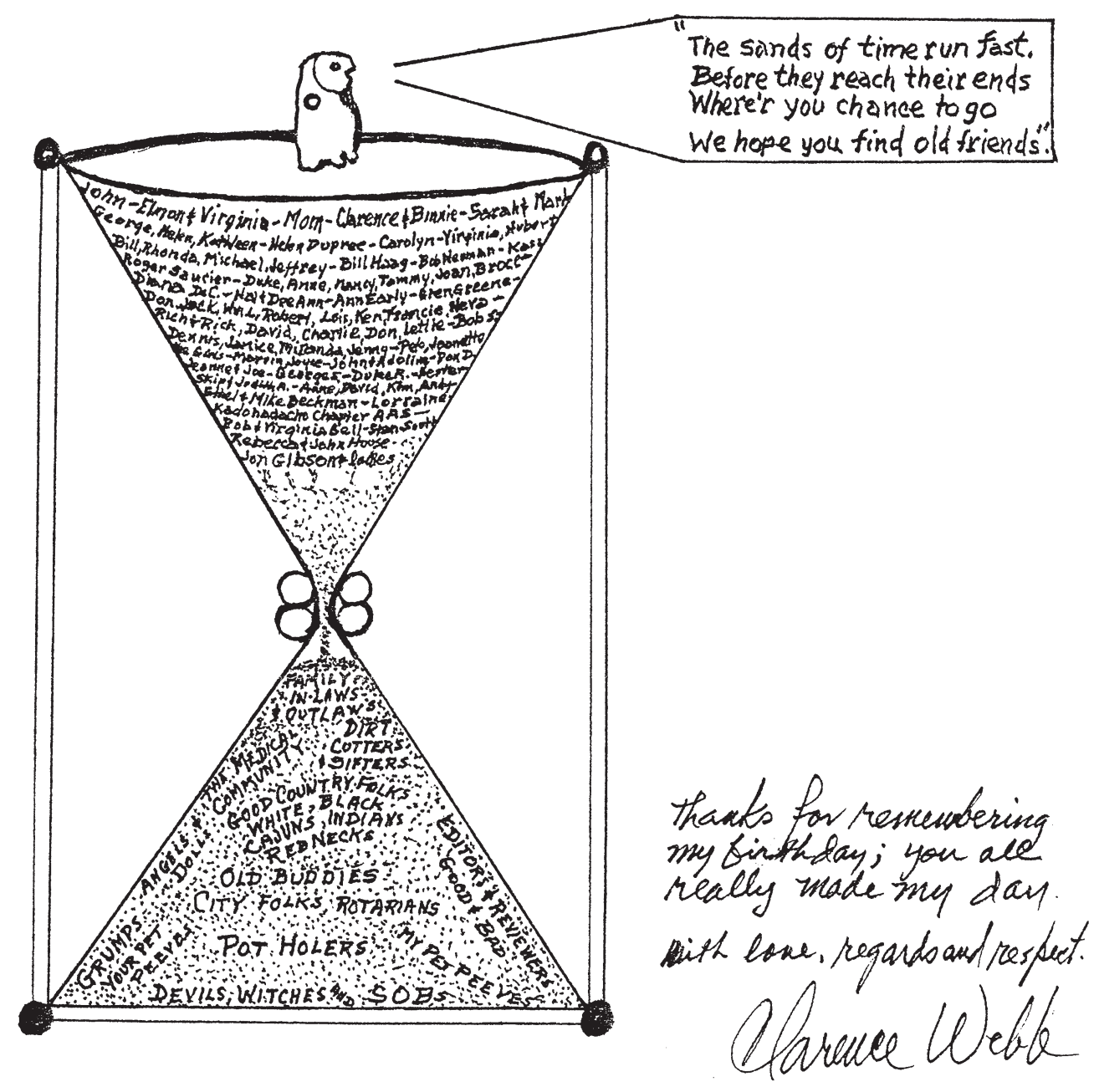

Figure 22. Clarence Webb's card in response to birthday greetings in 1990.

of the Great Bend area of the Red river, and Caddo in the Arkansas River Valley and the Ozark Mountains to the north. There were unidentified discussants, and a full four hours for this part of the program.

Saturday morning started out with a "Semi-business Meeting." Topics include financial report, Caddo Scholarship Fund, Caddo Archeology Newsletter, the Caddo Conference itself (organization), a 'central home' for the conference, out-dated mailing list, etc. The Caddo Scholarship Fund may have been created during the 1990 meeting, because a note with the preliminary announcement of this meeting says that the "first scholarship will be presented to the Caddo at the Texas Archeological Society Field School in June to be held on the Red 
River in Northeast Texas."). The first recipient was a Caddo girl who attended the University of Science and Arts Oklahoma (Cecile Carter, personal communication, July 2008). There may have been one or two other awards, but records have not surfaced and the fund no longer exists (Pete Gregory, personal communication, July 2008).

Back to Saturday morning, March 22. There were four current research reports between 10:15 and 11:30, and at 1:00 PM the field trips to the Washington Square Mound Site and the George C. Davis site set off, taking up the rest of the afternoon. The evening was to be spent at Millard's Crossing "relaxing" and having snacks/ supper/beer/wine, etc.

\section{2, Thirty-fourth Caddo Conference, Bossier City, Louisiana, March 20-21}

The first two papers were in recognition of Clarence Webb's contributions to Caddo archeology. A half hour break allowed people to look at books on sale. The final two items on the program for the morning dealt with repatriation: the procedures were discussed by Hester Davis, Darrell Creel, and Bob Brooks; and the responsibility of museums in inventorying their collections and human remains was covered by Elaine Reynolds of the University of Arkansas Museum.

Friday afternoon was devoted to current research with six papers scheduled. There was a wine and cheese reception at the Louisiana State Exhibit Museum in the evening.

Nine research reports were on the program for Saturday, covering everything from geoarcheological investigations to testing an antebellum Choctaw "homestead" for its eligibility for inclusion in the National Register of Historic Places. There were also three papers on aspects of accumulated information about the Crenshaw site in southwest Arkansas. Then a half hour was allotted for General Discussion on "Early Caddo, Origins, and Development," with the regular "business meeting" at the end to decide who was to host next year's meeting. There was the traditional free beer/cash bar party at the conference hotel to finish off the meeting.

\section{3, Thirty-fifth Caddo Conference, Norman, Oklahoma, March 11-14}

The Bureau of Land Management (BLM) had requested of Don Wyckoff, the program chair, that some time be set aside when personnel from the Oklahoma Resource Area Office could have a "meeting with the BLM permit holders working in Kansas, Texas, and Oklahoma." This was planned for Thursday afternoon. The regular meeting began at 9 AM on Friday morning, with seven papers dealing with diverse topics as usual, from 1930s Works Progress Administration projects in Oklahoma to one with the provocative title "A Look at the Relationship between the Spiro and Toltec Centers on the Arkansas River: A View from the Nile Valley." There were seven papers in the afternoon as well, from "The Ghost Dance among the Caddo" to "Rocks of Central Arkansas."

Seven papers also took up Saturday morning. The business meeting was scheduled for right after lunch, and two more papers were read before the Caddo dancers and drummers began the Turkey Dance about 4:30 (remember? The Turkey Dance must be finished before dark.) This time the Caddo came to Norman rather than the archeologists going to Binger.

An "Open Discussion Session" was scheduled for Sunday morning. There are no notes in my files as to whether anyone participated in this part of the program offerings. 


\section{4, Thirty-sixth Caddo Conference, Fayetteville, Arkansas, March 24-27}

This conference was held in the University of Arkansas Continuing Education Center, which is attached to the conference hotel on the historic town square. Visitors gathered on Thursday evening for a cash bar reception at the Hilton.

The Friday morning schedule was indicated on the program as running from 8:30 to 12:00 with no divisions as to how many minutes each paper should last (Figures 23 and 24). There were, however, eight papers on the program, largely of the current research variety. Friday afternoon's program was from 1:30 to 5:00, with four papers and a Panel Discussion scheduled entitled: "The Great Mound Robbery and Spiroan Entrepots." The topic of the discussion was to be Schambach's recent interpretations of Spiro, with which several archeologists did not agree. It was undoubtedly a spirited discussion.

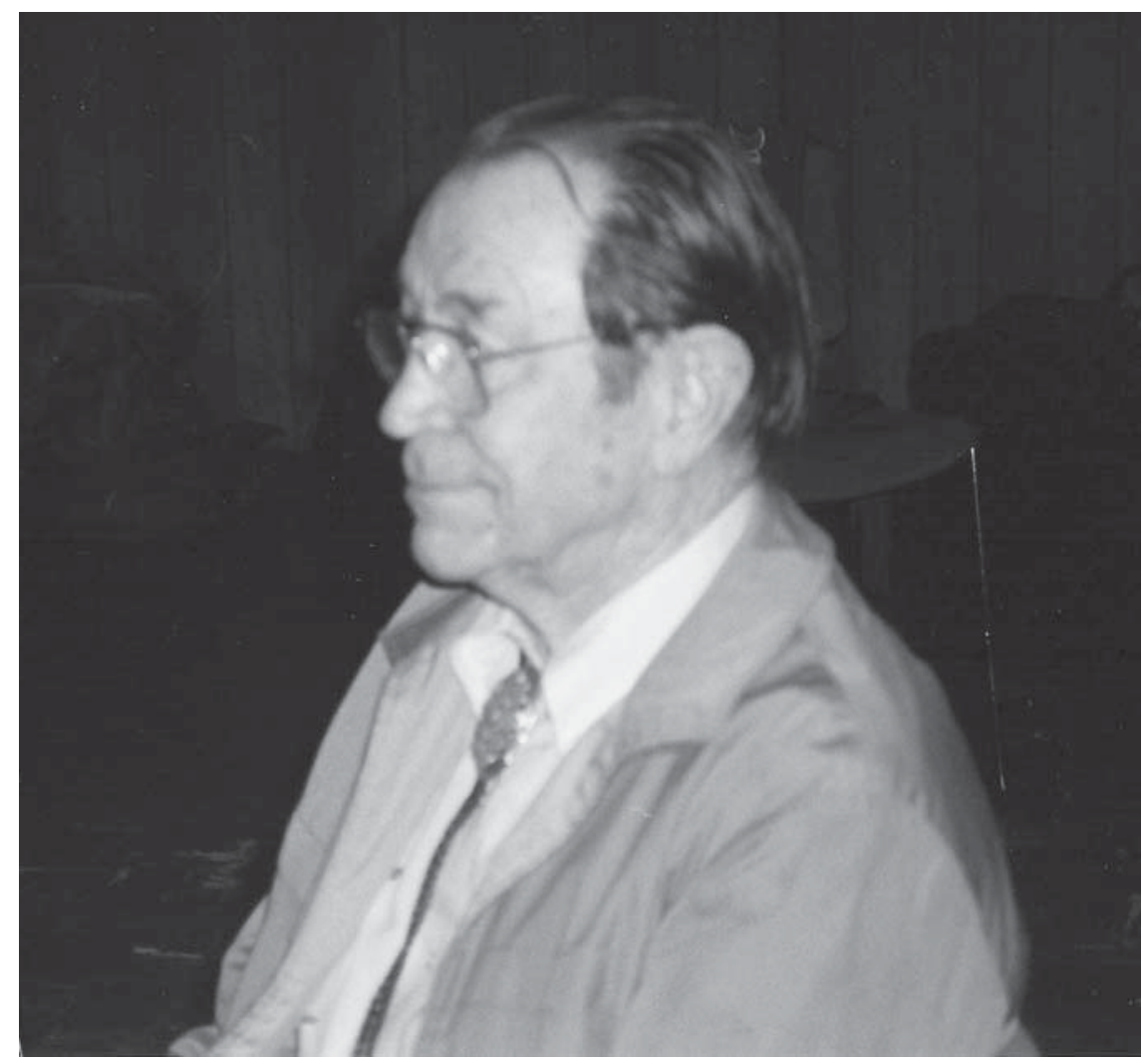

Figure 23. Phil Newkumet at the 1994 Caddo Conference.

Friday night was the "traditional" party at the home of Norma Hoffrichter (called a reception on the program, but we know better).

Sixteen papers were scheduled for Saturday, the large proportion being in the "current research category." The exceptions were a presentation by Linda Harris Brown, talking of her father's (King Harris) research and his collections, which had been donated to the Smithsonian Institution, and a description by Dennis Peterson, Superintendent at Spiro Mounds State Park, of plans for new exhibits at the Visitor Center.

Saturday, from 5:00 to 10:30 PM, members of the Caddo dance group hosted a banquet and dance performance at the University's Student Union building. My recollection is that there was a raffle, tickets being available dur- 


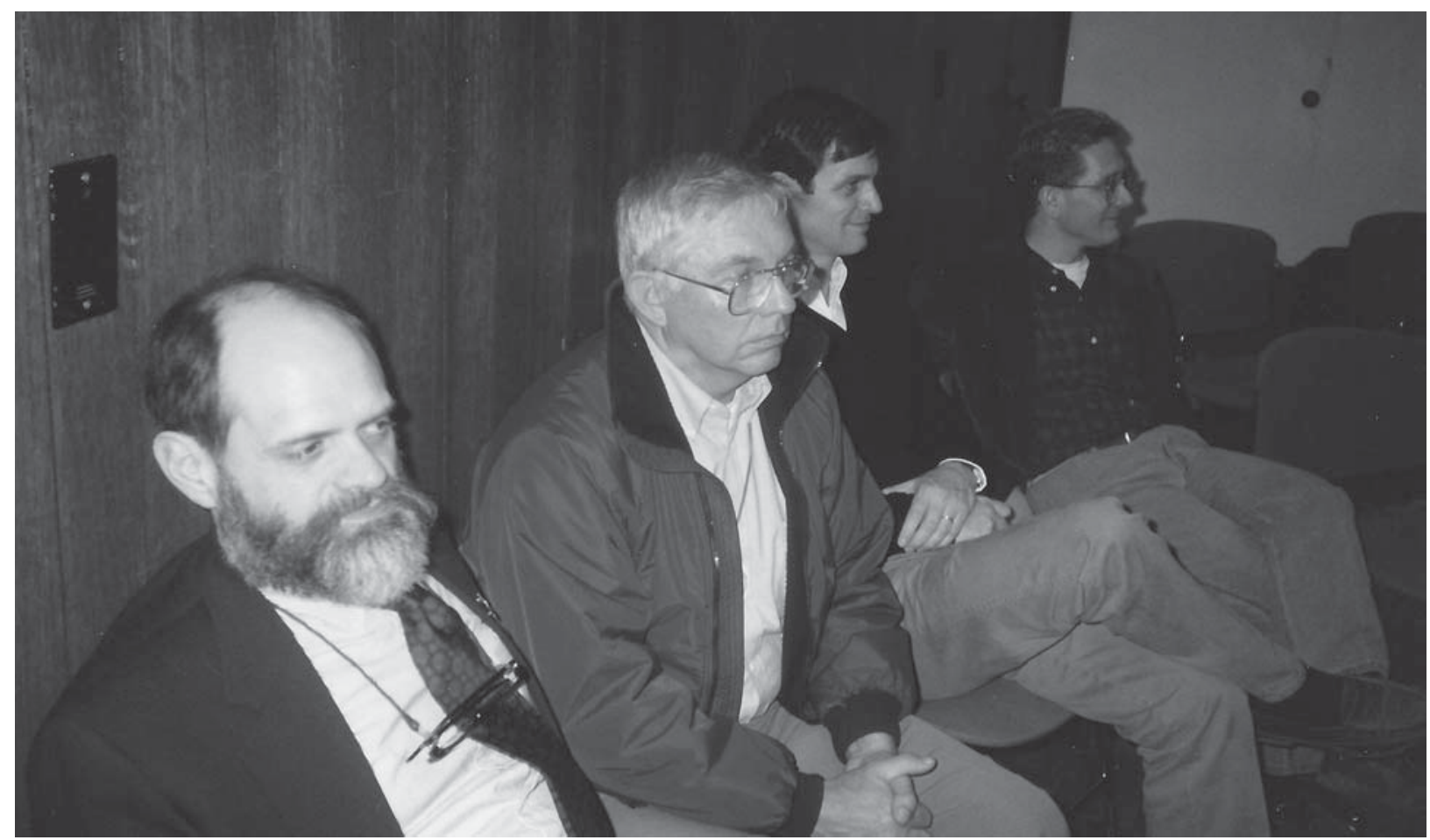

Figure 24. Left to right: Charles Rohrbaugh, Don Wyckoff, Darrell Creel, and George Sabo at the 1994 Caddo Conference.

ing the two days of papers, to help reimburse the Caddo for their expenses. The prize was a framed needlepoint hawk dancer figure, copied from one embossed on copper from the Etowah site, executed by Hester Davis, who copied one that Martha Rolingson designed, and won in the drawing by Kathy Cande, archeologist with the Arkansas Archeological Survey.

Sunday morning plans had been made for site tours, videos, and the viewing of a traveling exhibit at the Spiro Mounds State Park. For those who had flown into Fayetteville, George Sabo, Program Chair, had made arrangements for round-trip transportation to and from Spiro to make sure individuals got their return flights home.

\section{5, Thirty-seventh Caddo Conference, Austin, Texas, March 23-25}

For some unknown reason, I kept a copy of the reservation form, so that it is possible to report that the Registration Fee for this year was $\$ 20$, for students $\$ 15$, and the banquet and dance program $\$ 15$. There was also a space to make a contribution to the Caddo Scholarship Fund.

Friday's schedule included 10 papers on current research including remote sensing, iconography, ethnoarcheology, and a few reports on field work. There was also a video entitled: "Caddo Thoughts on Repatriation, Keepers of the Indian Way," put together by Berna Love of the Museum of Discovery in Little Rock, followed by "Comments on Caddo Tribal Heritage and NAGPRA" by Cecile Carter, Caddo historian.

There was an Open House at the Texas Archeological Research Laboratory starting at 3 PM, and in the evening a reception at Mike and Karen Collins' historic Moore-Hancock Farmstead. The Collins bought the property in 1989 and proceeded to conduct archeological investigations to identify the location and function of all the buildings, and then began restoration of at least three buildings, completing the work in 1992. The farmstead is now the permanent home of the Collins family. 


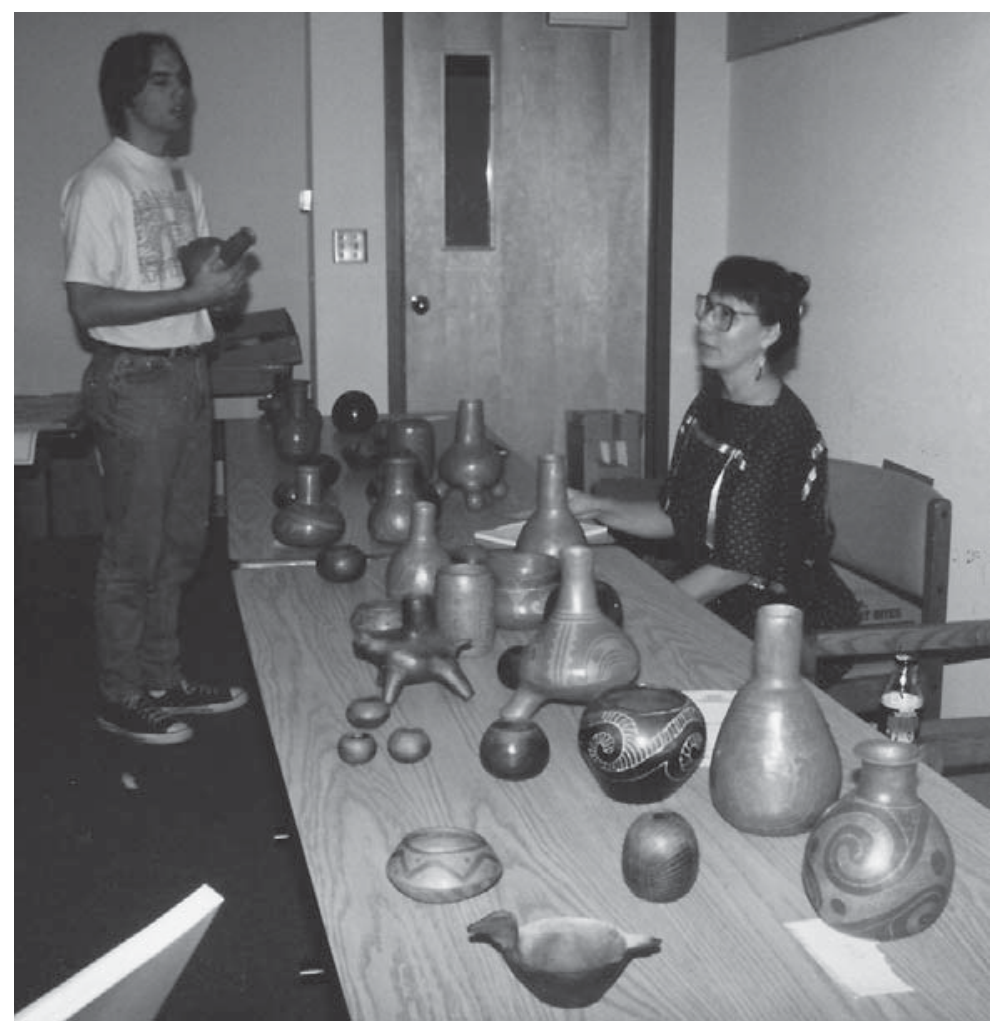

Figures 25. Jeri Redcorn and her pottery vessels at the 1995 Caddo Conference.

There were two symposia organized for Saturday. One in the morning was titled: "Caddoan Bioarcheological Research," with five papers and a discussant; the other in the afternoon was: "Current and Future Directions in the Study of Caddo Ceramics," a topic of interest to Caddo archeologists for just about 50 years at this point. One of the papers was even on an old familiar topic-the "Type-Variety System of Ceramic Classification." There were 10 papers and a discussant (Figures 25 and 26).

Saturday evening arrangements has been made to bus all the out-of-towners to the Salt Lick Restaurant where the Caddo Culture Club preformed traditional dances before and after a barbecue dinner.

\section{6, Thirty-eighth Caddo Conference, Natchitoches, Louisiana, March 29-30}

The program for this conference, held on the campus of Northwestern State University, presented the title and abstract for each of 10 papers presented on Friday. The time given for each paper varied from half an hour to an hour. This would have given plenty of time for discussion. Several of the papers discussed the problems both the Caddo and archeologists were having dealing with the requirements of the Native American Graves Protection and Repatriation Act (NAGPRA). There were excavation reports, surveys of large areas, analysis, and historic research as well.

From 7 PM until whenever, it was noted that there would be a barrel of beer at Beaudion's Pizza and Pub.

Eight presentations are indicated for Saturday, this time with only a half hour for each. There is an indication that there was expected to be discussants and/or discussion after the formal presentation. Pete Gregory led a 


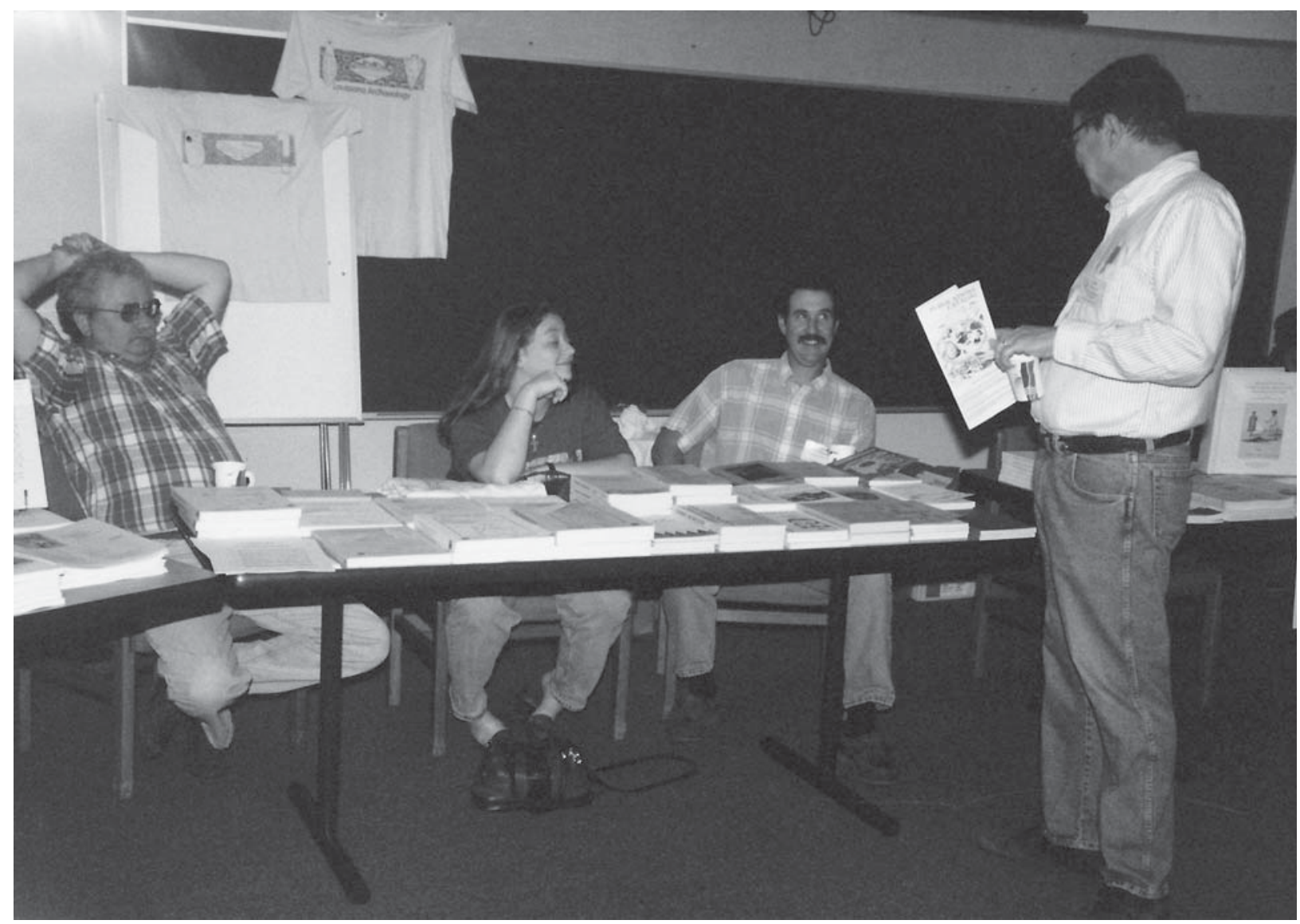

Figure 26. Louisiana folks selling publications at the 1995 Caddo Conference: Pete Gregory, standing; seated, left to right: David Jeane, Sara Hahn, and Rich Weinstein.

discussion of "Historic Caddoan Ceramics:" and there was another discussion session lead by Mark Barnes of the National Park Service, on "Discontinuous Historical Landmark Districts for the Caddo Mounds." Cecile Carter brought a video on The Turkey Dance; and Dayna Lee and Lowell "Wimpy" Edwards talked of "Music Traditions among the Caddo People."

Jim Corbin discussed the Juan Pedro Walker Map of 1806, and George Avery reviewed the results of excavation of stumps of storm damaged trees at Los Adaes. Finally, there was a presentation on "Mission Dolores" (without abstract or annotation), and from 3:45 to 5:00 a tour of Los Adaes. And there was the ever-present indication of a discussion on The Future of the Caddo Conference!

The conference ended at the Friedman Student Union Ballroom on the campus of Northwestern State University, with the traditional dance program by the Caddo Culture Club.

\section{7, Thirty-ninth Caddo Conference, Norman, Anadarko, and Binger, Oklahoma, March 13-15}

This was a busy and so far unique conference, with three venues in the two days. Friday's sessions were held on Dale Hall on the University of Oklahoma Campus, with an hour of field reports, and then nine papers. One was presented by the River Regional Studies Center giving "an explanation of their program and what they can 
do to help archeologists." There was also a two hour meeting scheduled from 5:30 to 7:30 at a local restaurant for the East Texas Caddoan Research Group, and there was an evening Open House at the Oklahoma Archeological Survey offices.

Saturday's sessions were held at Warrior Auditorium in Anadarko. Ouachita National Forest staff discussed the land exchange agreement with Weyerhaeuser, and sought opportunities for working together on a research design to investigate 85 known sites. A Tiak Research Discussion Group was established for this purpose. Vernon Hunter, Chair of the Caddo Tribe of Oklahoma, indicated issues of interest to the Caddo, and two other Caddo discussed the tribe's activities in preserving their past. After lunch, there were two papers on the Caddo language, and two on sites on the Red River in Louisiana. Perttula and Middlebrook discussed the Middle Caddo period and the activities of the East Texas Caddoan Research Group.

By 4:00 o'clock, the group was in Binger, ready for the Turkey Dance, dinner, and more traditional dancing.

\section{8, Fortieth Caddo Conference, Arkadelphia, Arkansas, March 13-14}

Starting at 3:30 Thursday afternoon there was an opportunity for early registration and a visit to the Arkansas Archeological Survey's Research Station in the historic house in which the Henderson State University Museum was located. From 5:00 to 9:30 PM, Ann Early, the Survey's Station Archeologist, opened her house not far from downtown and campus, for "hearty edibles and other refreshments. Additional personal libations at guests's discretion."

Two silent auctions were in place again for this meeting, one for help with the expenses of the conference, and one for the Arkansas Archeological Society's Archeological Research Fund. The latter are for grants given to archeologists whose projects have or will involve help from Society members.

Friday morning's schedule included nine papers, of 20 minutes each. In addition to reports on research on sites in Oklahoma, Arkansas, and Louisiana, there was one on Kansas, slightly out of the Caddoan area. In the afternoon, there were five papers on current research; one on a proposal for a Choctaw Conference; and one on the Caddo Tribe's NAGPRA endeavors. An hour was given to "issues facing Caddoan Archeology" (for example: NAGPRA, potential re-burial locations, new research directions, and a possible Caddo Cultural Center in Southwest Arkansas).

Friday evening was spent at a catered chicken and catfish dinner in a pavilion on Lake DeGray. I recall that this included good food and a miserably cold wind.

Saturday's papers included three about novaculite quarries and one on petrified wood as a resource; one on rebuilding the Caddo house at the Davis site; and three on research in the Winding Stair vicinity in the Ouachita National Forest in Arkansas. During lunch time there was a meeting of "Friends of Caddoan Mounds State Park," otherwise known as the George C. Davis site in East Texas.

In the afternoon, there were two papers on field work, one on oral history, and another hour scheduled for informal discussion from the floor on "current events and on-going work" (In other words, not enough people had sent in formal papers for this slot in the program.). The Caddo Culture Club presented their traditional dances, and "substantial" refreshments are reported to have been available. 


\section{9, Forty-first Caddo Conference, Jefferson, Texas, March 12-13}

The first announcement for this conference promised "something for everyone," and then listed the suggested symposia and workshops which might be of interest. The breadth of these topics indicates how both the conference and research has grown and changed with the times - the list deserves to be recorded here. In addition to "current research issues and questions concerning the archeology and history of the Caddo peoples," workshops/ symposia were solicited on: Late Caddo Societies on the Red River; Caddo Architecture; Historic Caddoan Archeology; Caddo Chronology-Building; Bioarcheology of the Caddo Peoples; Caddo Ceramics; Mound Building and Sacred Spaces; Subsistence Studies; and Caddoan History and Ethnohistory.

The organizers had considerable success in encouraging workshops and symposia on several of these topics. In fact, such success that there were slight time overlaps between them, with two presentations scheduled for the same time. Friday morning there was a general paper session with eight papers lasting from 8:40 to 11:35, and a workshop was scheduled (by the East Texas Caddoan Research Group, topic not indicated in the program) from 10:00 to 11:35. The workshop organized by Tom Middlebrook and Tim Perttula addressed current formulations of Caddo developments through time in three general regions of East Texas (the Red and Sulphur drainages; Cypress and Sabine drainages; and the Angelina and Neches drainages). Workshop participants summarized the Caddo cultural history in these areas and discussed key research questions that could refine the understanding of Caddo archeology in these areas.

After lunch three workshops were scheduled for an hour and a half each, but to do this, there had to be an overlap with two of them. No papers are listed, only participants in the discussion on the following topics: Caddo Architecture; Chronology Building in the Caddoan region; and Historic Ceramic Dating and Interpretation.

Saturday morning a Symposium on "Caddoan History and Ethnology" generated eight papers with both Caddo historians and archeologists participating. Overlapping this program slightly was a presentation/demonstration by Jeri Redcorn on "Making Traditional Caddo Pottery" (see Figure 25). The follow up on this activity was scheduled from 2:00-4:00 PM, again overlapping with the afternoon program of papers. This second part of Jeri's demonstration was on "Firing Traditional Caddo Pottery."

The Saturday afternoon session was on "Protohistoric and Historic Archaeology of the Southern Caddo: Change and Continuity," with seven papers, all of course, dealing with research in Louisiana and Texas but not Arkansas or Oklahoma.

Running through the two days was a raffle/silent auction to help pay for the Caddo Culture Club dancers and drummers/singers to come to Jefferson and perform on Saturday evening.

Finally, some hosts and organizers of past conferences had been able to identify additional help from sponsors in financing the meeting expenses. This meeting in Jefferson is a good example. Sponsors listed on the initial announcement are the Friends of Northeast Texas Archaeology, the East Texas Caddoan Research Group, and the Caddo Tribe of Oklahoma. (For at least one of the meetings in Norman, Oklahoma, Lois Albert was able to solicit local stores to give a $10 \%$ discount on food and drinks for the evening reception. Something for future planners to keep in mind!)

\section{0, Forty-second Caddo Conference, Natchitoches, Louisiana, February 25-26}

There are several new aspects to this meeting, the first being that the initial announcement indicated a theme: "YIK to Y2K: The Caddo and Their Neighbors." The program lists 22 local businesses, thanking them for 
donating door prizes! (What a great idea. That should assure that people will be in attendance at least at the end of each session!). In addition, "the Adai Caddo Tribe will host a reception dinner for the Caddo Tribe of Oklahoma, archaeologists, and guests attending the Caddo Conference," on Friday evening.

Eight papers were scheduled Friday morning, not including an hour for "Notes and News," and five papers in the afternoon, two of which were presentations by the Caddo of their NAGPRA activities.

Saturday eight papers were presented, ending at 3:15 with a discussion of ceramics-“Classification of Caddoan Pottery." The final program does not list the title of any of the papers, but abstracts are printed as part of the program, and a tentative schedule of papers, with titles, had been distributed before the meeting. Finally, the traditional Saturday evening program by the Caddo Culture Club was performed in the Northwestern State University Student Union Ballroom.

\section{1, Forty-third Caddo Conference, Norman, Oklahoma, March 15-18}

This conference was another opportunity to learn what is going on to the north of the Caddoan area, as this meeting was a joint one with the $23^{\text {rd }}$ Flint Hills Conference. In addition to sponsorship by the Caddo Nation of Oklahoma, the Oklahoma Archeological Survey, the Sam Noble Oklahoma Museum of Natural History, and the Wichita and Affiliated Tribes were sponsors.

Thursday evening, Lois Albert opened her house and provided supper for those who were there in time. Friday morning started with Don Wyckoff and Bob Brooks providing a short history of both conferences. The remainder of the day was devoted to current research papers from Oklahoma, Kansas, and Arkansas. The papers ended at approximately 4 PM, and were following by a "Wichita Traditional Singing Symposium."

Saturday morning there were more papers dealing with history and prehistory in the three states. One presentation was about the creation of the Kiwat Hasinay Foundation, which helps preserve Caddo language and oral traditions. From 10:15 to noon there was a symposium planned by the Caddo and broken into three sections. The symposium was titled: "From Footpaths to Expressways: Caddos Pave Their Way into the $21^{\text {st }}$ Century." Section I had three presentations and discussion on Traveling Traditional Pathways; Section II, Entering the Up Ramp, introduced the department heads within Caddo Tribal government and their responsibilities, with a summary by LaRue Parker of current programs. Section III, The $21^{\text {st }}$ Expressway, brought four speakers discussing on-going projects dealing with archeological site recording in the Caddo Homeland, Native American Self-Determination, and Influencing Government Policy.

The first two hours of Saturday afternoon were devoted to a discussion session on "Regional Variation and Protohistoric Caddo Identity," with 10 people primed to participate in the discussion (see Lee 2001). By 3:30 it was time to drive to Binger for the traditional dinner and dancing hosted by the Caddo Culture Club.

Sunday morning the Oklahoma Archeological Survey was opened for a "final wrap-up" which usually meant getting a commitment from a willing host for next year's meeting. The Oklahoma Archeological Survey was also ready for an "artifact comparison session."

\section{2, Forty-fourth Caddo Conference, Nacogdoches, Texas, March 15-16}

Again, an impressive array of sponsors helped in the creation of this meeting: Stephen F. Austin State University (SFASU); SFASU Anthropology/Archeology Club, SFASU College of Forestry, SFASU Department of Sociology, the East Texas Archeological Society, and the National Forests and Grasslands in Texas. 
Friday morning was devoted to research reports, six in all, of 15 or 20 minutes in length. After lunch, there were two papers on current research, and then, from 1:30 to 2:10, "Some Thoughts on Historic Constituent Groups in Southern East Texas" by Jim Corbin. There are no more papers, reports, or symposia/workshops listed for this day. At 6 PM there was a reception at Millard's Crossing.

Saturday morning from 9-10:00, the Caddo Culture Club presented a program of dance, songs, and drumming. The remainder of the day, with time out for a morning break, lunch, and one paper right after lunch on "Adai Ethnohistory and Oral History Project," there was an Open Forum on "Regional Sites and Socio-Political Identity" with 11 discussants; this was a continuation of the forum from the 2001 Caddo Conference. The program indicates that "Topics to be addressed include specific sites, the relationship of sites/foci/phases to specific groups, changes in population and settlement patterns, artifact samples, and possible tribal site predictors."

A banquet was held in the SFASU College of Forestry Conference Room. The Caddo Culture Club was to perform as usual, this time on the College of Forestry Grounds.

\section{3, Forty-fifth Caddo Conference, Arkadelphia, Arkansas, February 21-23}

There must have been a slim response to the call for papers, because the first thing on the schedule for Friday morning, was a "pre-conference Open House" from 8:30 to 12:00 at the Arkansas Archeological Survey's Research Station. Mary Beth Trubitt was now Station Archeologist at Henderson State University (HSU).

Friday and Saturday conference sessions were at the Garrison Center Lecture Hall on the HSU campus. On Friday afternoon, the Caddo Nation Youth Color Guard presented the colors, and the attendees were welcomed by Mary Beth, HSU President Charles Dunn, and Caddo Tribal Chair LaRue Parker. Session 1 contained seven papers on "Recent Archeological Research" which took up the rest of the afternoon. Supper was "on your own," followed by informal socializing at Thrio's Coffee House in Arkadelphia.

Session 2, on Saturday morning, consisted of three papers on "Novaculite Procurement and Use." Session 3 was a discussion session on the "Louisiana Purchase and the Caddo," with Ann Early as chair and six discussants. Session 4 dealt with "Caddo Culture and Heritage," and had four papers. This session was followed by the conclusion of the Silent Auction.

At 4:00 PM, Billie Ruth Hoff talked about the Caddo Swing Dance, with members of the Caddo Culture Club demonstrating. The printed program gave a special thanks to the Red Earth Museum in Oklahoma City for loaning HSU the Caddo Swing Dance Doll exhibit for display during the conference. The Turkey Dance took place at 5:00, a buffet banquet following, with traditional songs, drumming, and dancing by the Caddo Culture Club at 7:30.

Two field trips were planned for Sunday morning. One was a guided tour, by Ann Early, of the Barkman Mound just outside Arkadelphia; the other was a tour lead by Meeks Etchieson of the Ouachita National Forest, to some novaculite quarries at Magnet Cove. Those who know Meeks' long stride were glad to hear: "This will not be a strenuous hike."

\section{4, Forty-sixth Caddo Conference, Natchitoches, Louisiana, March 12-13}

Friday morning's session could be called current research, although it did not cover only field research. Bob Neuman talked about Native American Tent Camps; U.S. Forest Service personnel and Caddo Cultural Preservation Office staff discussed "Technology Transfer;" Pete Gregory's paper was on "Snake Woman: Mythology and Ceramic Motifs," and there were nine papers altogether. 
Friday afternoon there was a two hour session on the "Caddo Role in Expanding Native American Involvement in the Celebration of National American Indian Heritage Month," with six people making presentations. A final paper was given telling of the Caddo properties that have been purchased by The Archaeological Conservancy (as of 2008, the total is 11, seven in Texas, one in Oklahoma, and three in Arkansas).

Saturday morning was taken up with one session on "Caddo Regional Interaction," harking back to the interests of the conference's founders. Three papers dealt with Spiro and Caddo interactions, one on the Caddo in North Louisiana's Pineywoods; two more discussed Coles Creek, and one was on "Caddoan Expression at Fort Polk." After lunch there was a little over an hour for more discussion of the Regional Interaction topic.

Then came an innovative half hour: "A Caddo Style Show: Traditional Clothing and Regalia." Previously, we had been used to seeing the Caddo Culture Club women in their dance clothing, with ribbons and silver combs, all of which must have certain meanings.

The Turkey Dance was performed around 4 PM There was a break for dinner, and then the evening of dancing began.

\section{5, Forty-seventh Caddo Conference, Norman, Oklahoma, March 17-19}

There were five papers in the Friday morning session, two of which were reporting on recent excavations; one on Fourche Maline; one on the McKinney Collection from Mounds Plantation (Ralph McKinney helped Clarence Webb during his excavations at this important site); and one was looking at "Spiro and other Centers through the Use of Metaphor."

For the afternoon, there were two reports on recent research, one on lithics and one on the analysis of a human burial. Two more papers were on the Hasinai language, and one discussed a large collection of Caddo pottery recently "rediscovered" at the American Museum of Natural History from 1900 excavations at the late $17^{\text {th }}$ century Clements site in northeastern Texas.

There was then time for a general discussion from the floor of current research. There were no plans for evening entertainment.

Saturday morning there were five more papers, three of which were on aspects of the research on the BrysonPaddock site, an early $18^{\text {th }}$ Century Wichita village in Oklahoma. John Barr gave a paper on "Henri de Tonti with the Natchitoches, 1690," and Dan Rogers' paper dealt with "Chronology and the Demise of Chiefdoms in Eastern Oklahoma in the $16^{\text {th }}$ and $17^{\text {th }}$ centuries." Saturday afternoon three papers were presented, one on "Historical Archeology in Northeastern Oklahoma;" one on the Southeastern Ceremonial Complex and Caddo History; and one with an intriguing title: "What One Learns Chasing After an Alligator...Dance."

Around 4:30, the Turkey Dance began. You were on your own for dinner after the Turkey Dance and before the rest of the traditional dancing by the Caddo Culture Club.

\section{6, Forty-eighth Caddo Conference, Nacogdoches, Texas, March 10-11}

This conference was overlaid with remembrances of Jim Corbin, long time professor at Stephan F. Austin State University, four-time host of the conference, with many friends in attendance. Jim had usually brought the conference up to date on his research with field school students at the Washington Square Mound site in downtown Nacogdoches. Jim passed away in late November 2004. 
Two papers on Friday morning dealt with the Washington Square Mound research, and one was on "Caddoan Burial Practices and Beliefs in general." Three more were reports on current research on Texas, Arkansas, and Oklahoma. The afternoon was taken up by a symposium entitled: "Jim Corbin and East Texas Archaeology," with 12 speakers, including both Caddos and archeologists, talking of their experiences and remembrances of Jim. The evening, from 7:00 to 10:00, was taken up by a Special Reception "honoring the memory of our colleague and friend, Dr. Jim Corbin." There were "heavy hors d'oeuvres, a cash bar, AND live music/ entertainment."

Saturday morning there was another symposium on "Geographic Information Systems and Caddoan Archeology," with eight people participating in the discussion. Frank Schambach reviewed the usefulness of GIS in the research at "A 15h Century Caddo Ceremonial Center, The Tom Jones Site, in Hempstead County, Arkansas."

After lunch there was one more site report and then Jeff Girard lead a discussion of "Caddo Ceremonies and Ceremonial Centers," until 3:00 PM. A "business meeting" followed; and the Silent Auction came to an end. From 4:30 to dusk, there was the Turkey Dance by the Caddo Culture Club and the Hasinai Dance group at the George C. Davis site.

\section{7, Forty-ninth Caddo Conference, Magnolia, Arkansas, March 15-18}

Southern Arkansas University is a small institution but there was a new Reynolds Center which had new facilities and an auditorium big enough for all of us- "located deep in the beautiful pine forests of southwestern Arkansas and in the original heartland of the Caddo." There was also a new Arkansas Archeological Survey Station Archeologist, Jamie Brandon.

The Friday morning session, after the welcoming speeches, contained six presentations on current research, one of which had 12 authors - that being the continuing research on the use of Switchgrass by the Caddo for house construction. In addition, Ann Early brought everyone up to date on the changes in the Arkansas Antiquity Act, making it a felony to remove $\$ 1000$ worth of artifacts, or to do $\$ 1000$ worth of destruction on private land without the landowner's permission.

Friday afternoon Bobby Gonzalez reported on the Caddo Nation Cultural Preservation Department's activities. There followed a presentation on "Arkansas' Rock Art Database," and a discussion lead by David Jeane on the possibility of an "Online Caddoan Ceramic Database," the modern version of the Ceramic Depository suggested 61 years ago (see Appendix II).

After the mid-afternoon break (Figure 27), there was the usual "'business meeting," with an invitation from Pete Gregory for the conference to have its $50^{\text {th }}$ meeting at Northwestern State University in Natchitoches. There was a reception at 7 PM at the Best Western Coachmen's Inn Party Room.

Saturday morning there were nine research papers, some on lithics, more on ceramics, one on a documentation of the Hodges collection owned by the Joint Educational Consortium in Arkadelphia, and the remaining reports dealing with current excavations. Two papers were given in the afternoon, and there was then a discussion for the rest of the afternoon, with Pete Gregory as chair and four designated discussants on the topic of "Indian Goods-Indian Sites?"

Because the day was fair, the Turkey Dance took place on the Campus Mall starting about 5:30 pM (Figure 28). 


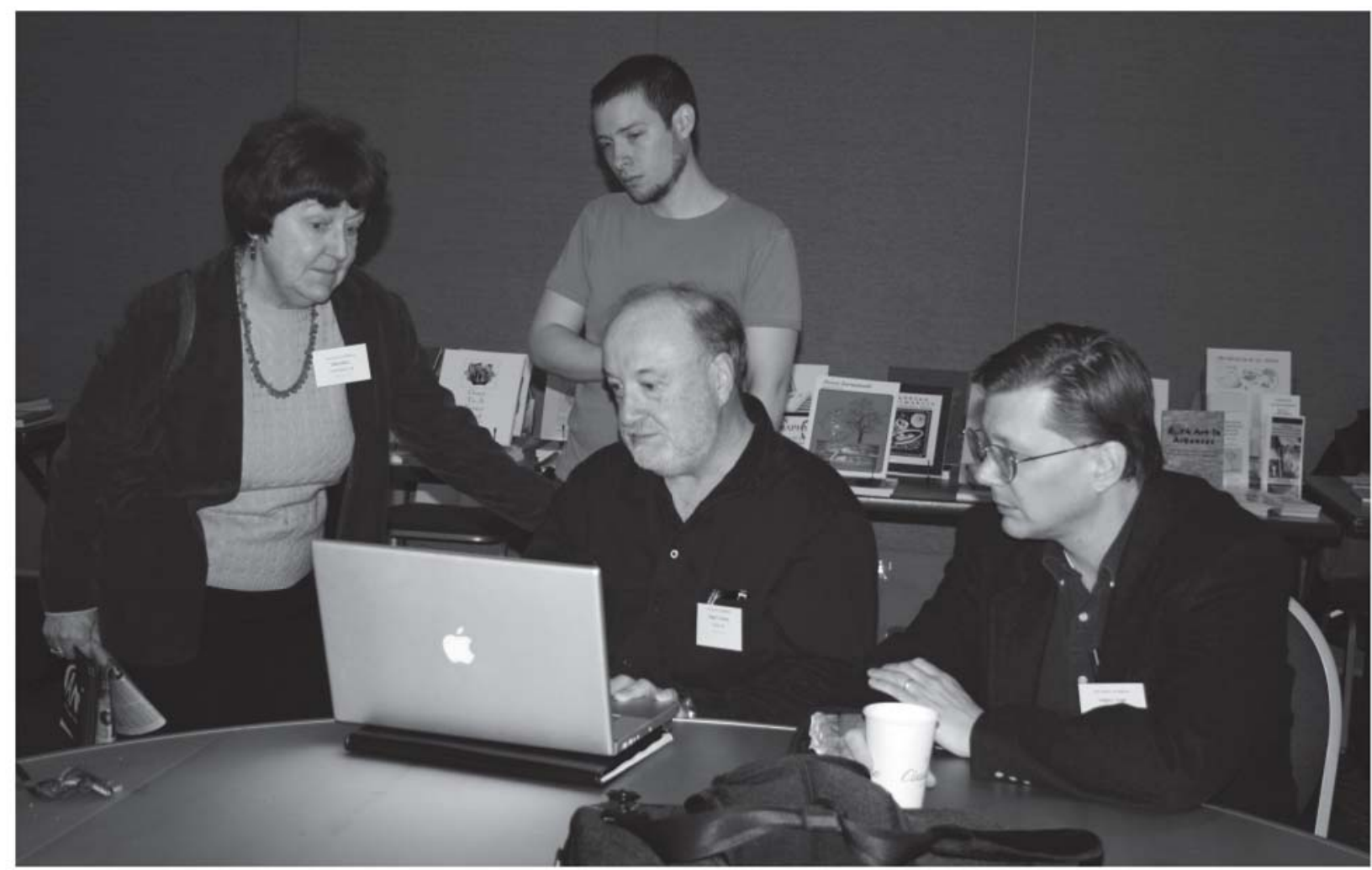

Figure 27. Forty-ninth Caddo Conference. Left to right, standing: Ann Early and John Samuelson; seated: Bob Brooks and Gregory Vogel.

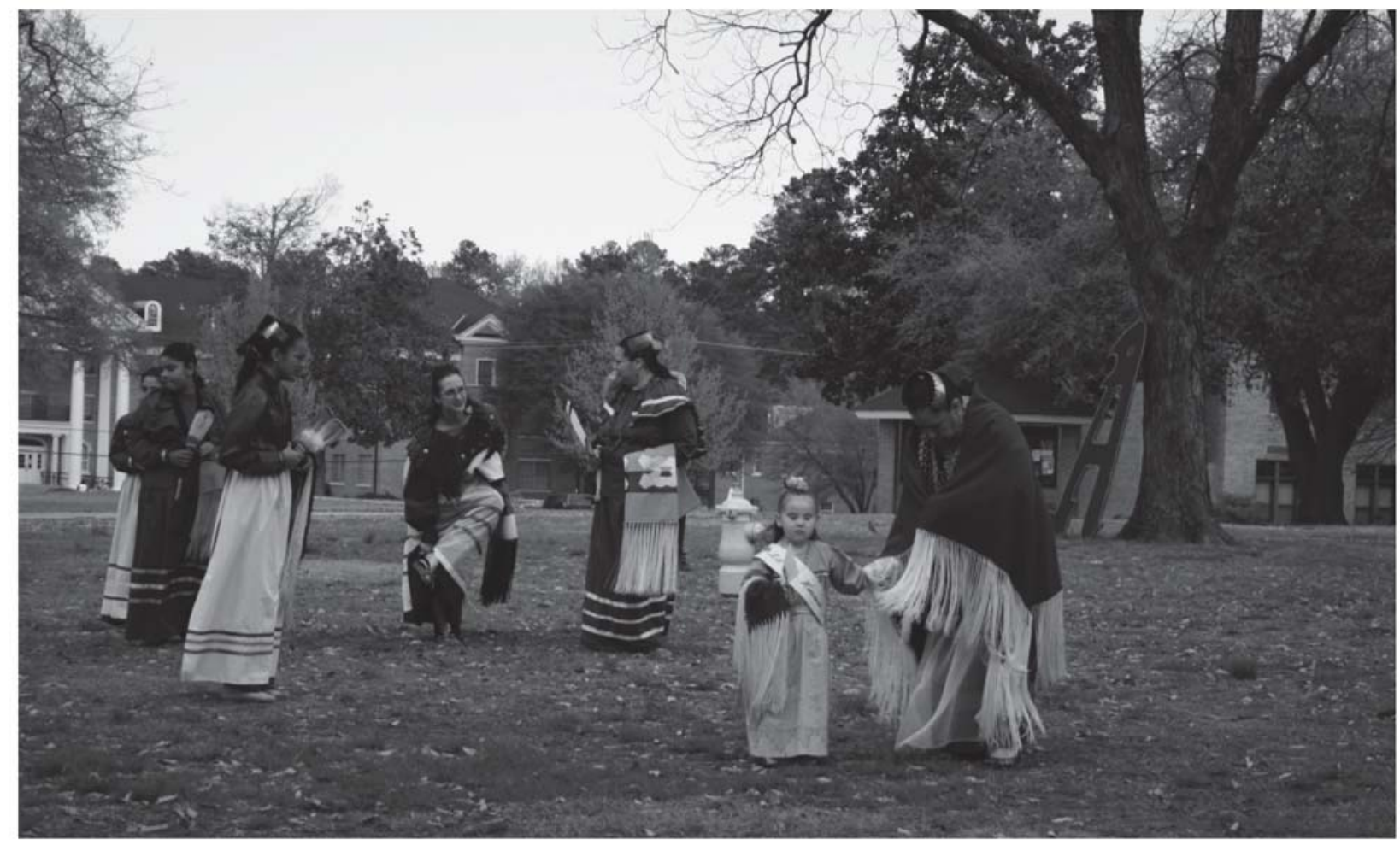

Figure 28. Caddo women dancers at the Forty-ninth Caddo Conference in Magnolia. 
There was a tour on Sunday morning of both the Crenshaw site and Battle Mound (Figure 29), allowing many of the Caddo to visit these large multiple mound sites for the first time. Several were able to obtain small branches from cedar trees to take home.

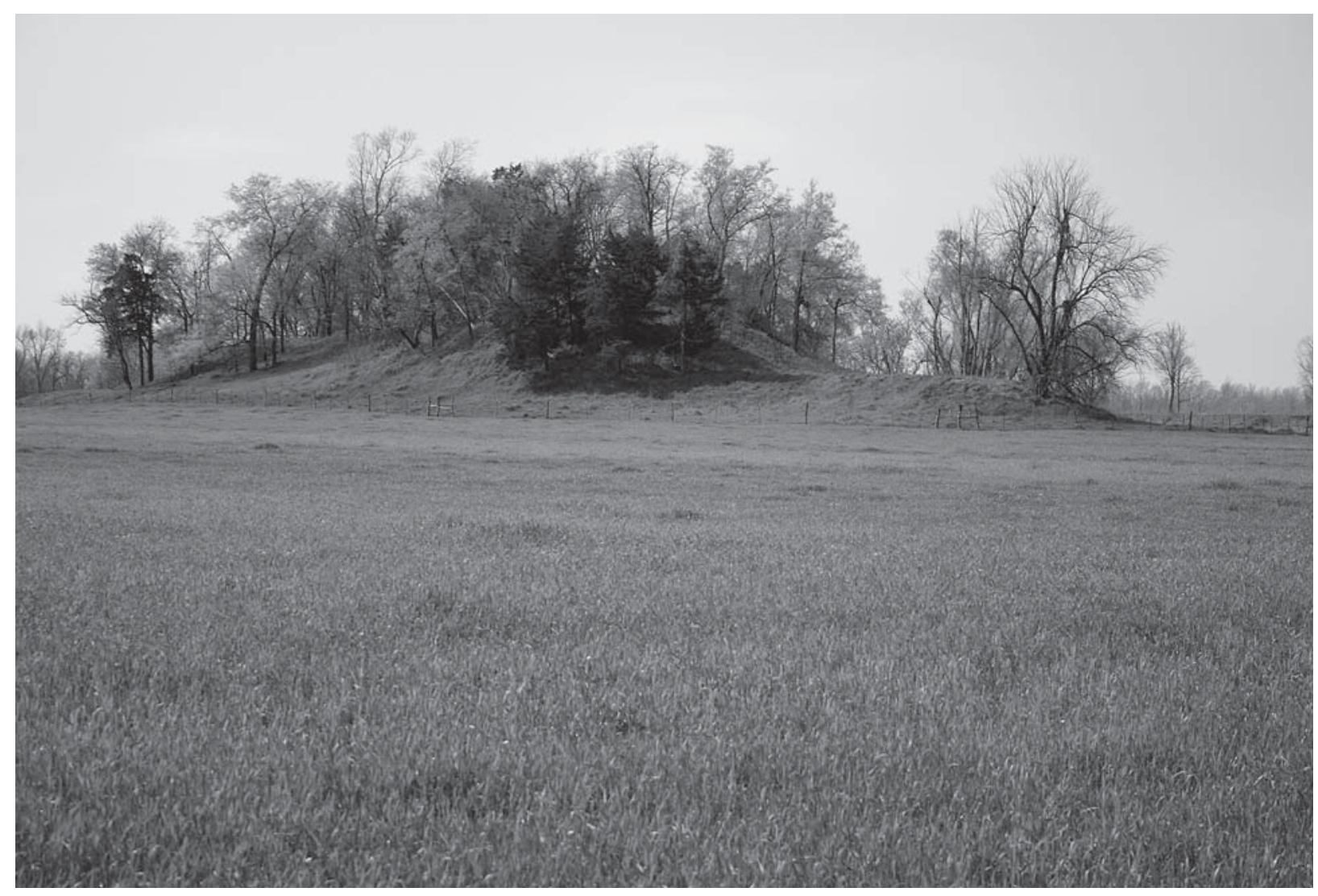

Figure 29. The Battle Mound at the time of the 2007 Caddo Conference.

\section{8, Fiftieth Caddo Conference, Natchitoches, Louisiana, March 6-8}

Perhaps because it is still strong in my mind, this Golden Anniversary of the Caddo Conference was by far the most memorable! It was probably one of the largest in attendance as well, there being a count of 160 people (Figure 30), 45 of whom were Caddo.

There was an opening reception with finger food and drinks Thursday evening, at the Williamson Museum on the Northwestern State University campus, with a good crowd of old friends in attendance. Available for distribution on this occasion was a 32 page "retrospective in pictures" of most of the conferences, which Dayna Lee had worked on for almost a year. Its publication was made possible by a grant from the Cane River National Heritage Area.

Earlier on Thursday, the Caddo had had a private ceremony at the site of the Fish Hatchery cemetery, reburying the remains of their ancestors.

After the welcoming ceremonies Friday morning, there was an official signing of a Memorandum of Agreement (MOA) between the Caddo Nation and the U.S. Fish and Wildlife Service, concerning the care, preservation, and 


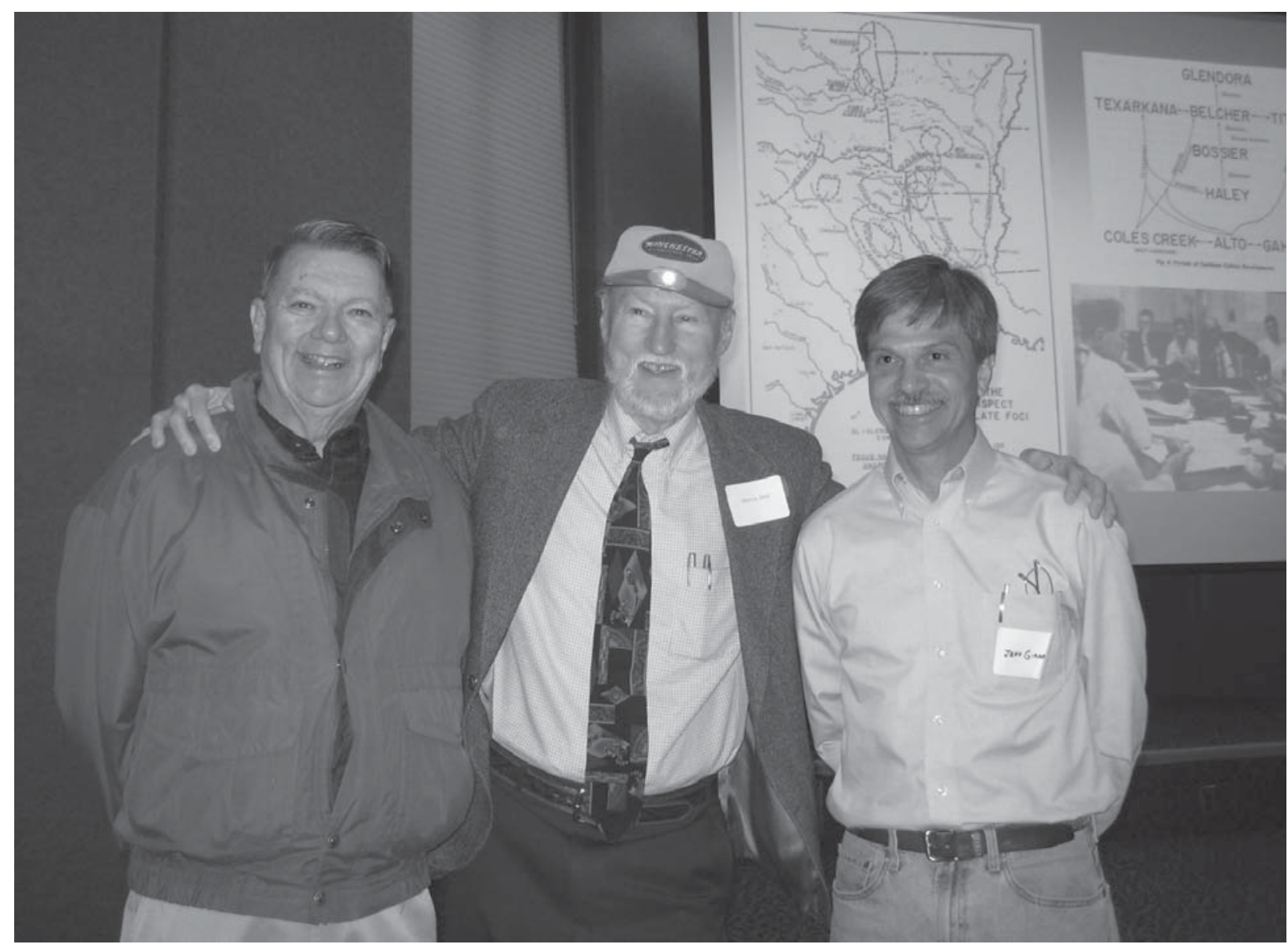

Figure 30. Left to right: Pete Gregory, Marvin Jeter, and Jeff Girard at the Fiftieth Caddo Conference. Photograph courtesy of Charlotte M. Copeland.

management of a Caddo cemetery which had been uncovered in the 1930 when the Natchitoches Fish Hatchery was being built. Winslow Walker, an archeologist with the Smithsonian Institution, had come to Natchitoches and excavated in the cemetery, taking a number of human remains and funerary objects back to Washington D.C. for study (Walker 1935). The Caddo Historic Preservation Department staff had worked for almost eight years with the U.S. Fish and Wildlife staff from both the Washington D.C. office and those at the Natchitoches office, as well as the Repatriation Office at the Smithsonian Institution, to reach this moment of agreement.

After that ceremony, Bobby Gonzalez, the NAGPRA coordinator for the Caddo Nation, presented a special award to two people, John Miller, an archeologist with the Arkansas Highway and Transportation Department, and his colleague, Randal Looney, who works for the Arkansas Division of the Federal Highway Commission. The plaque that each received reads:

In recognition of his efforts to foster consultation, preserve the history of the Caddo, and work directly with the Caddo Nation.

Presented on March 7, 2008, at the 50 $0^{\text {th }}$ Caddo Conference

Natchitoches, Louisiana

After the signing of the MOA and the presentation of the two awards, there were two papers dealing with the history of the conference and with what has been learned of Caddo archeology. There were three more papers after a break. 
From 11:30 to 2:00 on Friday, there was a "dedication of the Fish Hatchery Site Caddo Memorial Plaza at the National Fish Hatchery building. Lunch for all attendees will be provided at the site by F.I.S.H. (Friends in Support of the Hatchery)." What was NOT planned was a change in the weather. We had heard that it was snowing in Shreveport as well as in all of southwest Arkansas. Storms around the Dallas airport meant that several people who were on their way to the conference did not make it at all. There was no snow in Natchitoches, but as we drove from the University to the Fish Hatchery it began to rain and there was a strong, very cold wind. The Hatchery staff and FISH had known that the weather might not be wonderful, and there was a large white tent with tables and chairs for us, but the side of the tent which had to be left open for the dedication, was the side from which the wind was blowing. There were seven speakers at the dedication, as well as the lunch to be eaten, and although many were not prepared for the cold and rain, everyone huddled under the tent and experienced an exceptionally memorable dedication. The plaque at the Memorial Plaza reads:

\section{Sacred Ground Caddo Memorial Plaza}

The ground upon which you are standing right now is sacred ground. In the early 1930s, when the U.S. Fish and Wildlife Service began construction of this hatchery, over 100 Caddo Indian graves were unearthed. At that time, the Native American Graves Protection and Repatriation Act (NAGPRA) was not in effect and many human remains, as well as funerary items, were crushed, stolen, looted, or destroyed. Some remains were transported to the Smithsonian Institution in Washington, D.C. where they were kept in "The Nation's Attic" at the National Museum of Natural History until 2007. Under the authority of the Museum of the American Indian Act, and supported by the Caddo Nation's Tribal Council and Repatriation Committee, the Caddo Nation's Cultural Preservation Department began a long journey in 2000 to return these remains to their home - the home of their ancestors - the Caddo Nation.

The journey is now complete. This Memorial Plaza is dedicated to honor the culture of the Caddo Nation and to remind all that spend time here of the proud history they left behind.

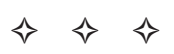

When all were returned from the dedication and we had warmed up, there were six more papers. Dinner that evening was "on your own."

Six papers were scheduled Saturday morning, and four in the afternoon, all on current research. Around 3:00 PM, Pete Gregory asked for any regional reports, and announced the "business" of choosing next year's host. This resulted in an invitation given by Bob Brooks, in the name of the University of Oklahoma, the Oklahoma Archeological Survey, and the Sam Noble Oklahoma Museum of Natural History. There was a rousing acceptance.

The traditional Turkey Dance was held in the Ballroom at 4:00 PM, where the conference had been held. We then went to St. Anthony's Catholic Church for a Creole dinner, then back to the Ballroom for more dancing, singing, and drumming.

\section{Here endeth the history of 50 meetings of the Caddo Conference.}




\section{WHAT IS TO BE LEARNED FROM THIS LONG STORY?}

Everyone might have a different answer to this question, and certainly archeologists attend enough other meetings to make some comparisons.

The Caddo Conference has kept its informality intact, at the cost of some of its history. However, it stresses the importance of keeping up with what is going on in the field by being sure that there is at least a half day, and often the equivalent of a full day, devoted to papers on current research. Opportunities for "networking" are assured in the evenings. And perhaps most important, there are now always opportunities for getting to know some of the Caddo, hearing their side of the "story" of the Caddo's past—we need to maintain the opportunity to learn from each other.

In terms of the accumulating information from archeological research which deals exclusively with this one tribe and its past, we have reached our present stage of knowledge in much the same way that most archeologists in North America have experienced growth and change in the way archeology is practiced. Interdisciplinary research, specializations such as faunal and floral analysis, bioarcheology, pollen identification, remote sensing, these and other, all together mean we are able to suggest more about the daily life of those who have gone before us, and about how Caddo culture has changed over several millennia.

Certainly how we manipulate archeological data to come to the "conclusions" we make has changed, and equally certain is that the questions we ask of the data are different. The questions of chronology and the nature of material culture are very different now. Ed Jelks, in an April 28, 2008 letter to me, described briefly the two areas of interest for the founders of the conference, which are barely touched on in the papers given in the last 20-30 meetings:

There were two main issues [of the founders of the conference]: (1) correlating the Caddoan phases with the Mississippi Valley phases, and (2) explaining the similarities between the Southeast US and Mesoamerica. Southeast temple mounds, ceramic traits, and especially religious art motifs in Southern Cult materials (e.g. figures on carved conch shells at Spiro and other major Mississippian mound sites) made it evident that there was some kind of historical connection between Mesoamerica and the Southeast US. Krieger argued that because the Caddoan area was closest of the Mississippian expressions to Mesoamerica, it was likely that Mesoamerican traits entered the Southeast US there. But how were the traits actually transmitted? Overland through the so-called Gilmore Corridor? If so why had no archeological evidence been found within the Corridor? Along the coastal beaches where evidence could have been removed by erosion? Or were they brought by boat across the Gulf to the lower Mississippi Valley, by-passing the Caddo area completely. Did Mesoamericans colonize the Southeast? Did missionaries bring a Mesoamerican religion to the Southeast, including religious art forms? Did some Southeastern Marco Polo-type visit Mesoamerica and bring back home all these new ideas that were adopted by his people?

Ed goes on to say that the "new archeology" was adopted by Caddo archeologists starting in the 1960s. There were new theoretical approaches and new questions to be asked: "rigorous hypothesis testing, general systems modeling, recognition of settlement patterns, how efficiently a society utilized available energy resources, research designs involving applications of statistical formulas, and all that jazz." We seem now to have gone even beyond those lessons that Lewis Binford taught us. Cultural resource management requirements since the 1970s have given us new challenges, in applying new theories and new methods, but much less in the way of new questions. You will find these changes sprinkled amongst the papers in the last few decades of the Caddo Conference. 


\section{WHAT ABOUT THE FUTURE OF THE CADDO CONFERENCE?}

You will have noticed, I trust, that three or four times scattered through the summaries of the conferences since 1989 that the program chair had scheduled a discussion on the future of the Caddo Conference. In one case, four people were asked to consider various alternatives and report at the next meeting (at least that is what I assume happened-there is nothing in the files about what was discussed or what was in the report).

We like to go to meetings and network with our friends and colleagues, but we maintain the informality of the past, shunning bureaucratic organization that requires membership dues which would pay for the printed word. Or perhaps we just forget to resubscribe to the $C A J$ unless we are nagged mercilessly. It might be interesting to compare the mailing list for the $C A J$, and the mailing list for the conference. I'll bet many more people come to the conference than subscribe to the $C A J$.

I would make a final observation that if, at the coming of the $75^{\text {th }}$ Caddo conference, someone wants to know what we have been doing the last 25 years, we better find a volunteer to be our Conference Archivist. We probably also need to find a volunteer to be "secretary" of each meeting (a position held by Mott Davis for about 30 years), someone who gets copies of the papers read, who takes notes during discussions, and who records other "happenings."

\section{REFERENCES CITED}

Bell, Robert E.

1952 Caddoan Area. American Antiquity 18:95-96.

Bohannon, Charles F

1962 Excavations at the Mineral Springs Site, Howard County, Arkansas. The Arkansas Archeologist 3(10):7-9.

1973 Excavations at the Mineral Springs Site, Howard County, Arkansas. Research Series 5. Arkansas Archeological Survey, Fayetteville.

Davis, E. Mott

1961a Proceedings of the Fourth Conference on Caddoan Archeology. Bulletin of the Texas Archeological Society 30:133.

1961b Proceedings of the Fifth Conference on Caddoan Archeology. Bulletin of the Texas Archeological Society 31:77143.

1961c The Caddoan Area: An Introduction to the Symposium. Bulletin of the Texas Archeological Society 31:3-10.

1961d Symposium: Relationships Between the Caddoan Area and Neighboring Areas. Bulletin of the Texas Archeological Society 31:27-37.

Davis, Hester A. (editor)

1966 Caddoan Area Field Reports, 1962-1964 Seasons. University of Arkansas Museum, (mimeographed). Fayetteville.

Davis, Hester A., Don G. Wyckoff, and Mary A. Holmes (editors)

1971a Proceedings of the Seventh Caddo Conference. Oklahoma Archeological Survey Occasional Publication 1. Norman.

1971b Proceedings of the Eighth Caddo Conference. Oklahoma Archeological Survey Occasional Publication 2. Norman.

Dickinson, Samuel D.

1936 Ceramic Relationships of the Pre-Caddo Pottery from the Crenshaw Site. Bulletin of the Texas Archeological and Paleontological Society 8:56-69. 
1941 Certain Vessels from the Clements Place, a Historic Caddo Site. Bulletin of the Texas Archeological and Paleontological Society 13:117-132.

1991 A Relic Looks Back. The Arkansas Archeologist 39:1-6.

Dickinson, Samuel D. and Harry J. Lemley

1939 Evidences of the Marksville and Coles Creek Complexes at the Kirkham Place, Clark Country Arkansas. Bulletin of the Texas Archeological and Paleontological Society 11:139-189.

Durham, James H.

1964 Notes on the 1961-1962 Excavations at the Crenshaw Site, 3MI6, in Arkansas. Oklahoma Anthropological Society Newsletter 21 (6): 4-8.

Durham, James H. and Michael K. Davis

1975 Report on the Burials Found at Crenshaw, Mound C, Miller County, Arkansas. Bulletin of the Oklahoma Anthropological Society 23:1-90.

Durham, James H. and Glen L. Kizzia

1975 A Deep Burial in Crenshaw Mound C, Miller County, Arkansas. Central States Archaeological Journal 1 (2):44-67.

Ford, James A. and James B. Griffin

1937 Conference on Pottery Nomenclature for the Southeastern United States. Reprinted in the Southeastern Archaeological Conference Newsletter 7(1):5-9. (October 1960).

1938 Report of the Conference on Southeastern Pottery Typology. Reprinted in the Southeastern Archaeological Conference Newsletter 7(1):10-22. (October 1960).

Gibson, Jon and Hiram F. Gregory (editors)

1992 Dr. Webb. Louisiana Archaeology 19:1-129.

Harrington, Mark R.

1920 Certain Caddo Sites in Arkansas. Miscellaneous Series 10. Museum of the American Indian, Heye Foundation. New York City.

Hodges, Mrs. T. L.

1957 The Cahinnio Caddo: A Contact Unit in the Eastern Margin of the "Caddo Area." Bulletin of the Texas Archeological Society 28:190-197.

Hodges, T. L. and Mrs. T. L. Hodges

1943 The Watermelon Island Site in Arkansas. Bulletin of the Texas Archeological and Paleontological Society 15:66-79.

Hoffman, Michael P.

1969 Prehistoric Developments in Southwestern Arkansas. The Arkansas Archeologist 10(1-3):36-49.

1970 Three Sites in Millwood Reservoir: The Hutt Site, the Stark Site, and the Beard Lake Site. Research Series 2. Arkansas Archeological Survey, Fayetteville.

Howard, James

1968 The Southeastern Ceremonial Complex and its Interpretation. Missouri Archaeological Society Memoir 6. Columbia.

Jelks, Edward B.

1995 J. C. Harrington Medal in Historical Archaeology: Kathleen Kirk Gilmore, 1995. Bulletin of the Texas Archeological Society 66:v-viii.

Kenmotsu, Nancy A. and Timothy K. Perttula (editors)

1993 Archeology in the Eastern Planning Region of Texas: A Planning Document. Cultural Resource Management Report 3. Department of Antiquities Protection, Texas Historical Commission, Austin.

Krieger, Alex D.

1946 Culture Complexes and Chronology in Northern Texas, with Extensions of Puebloan Datings to the Mississippi Valley. Publication No. 4640. The University of Texas, Austin. 
1947 The First Symposium on the Caddoan Archaeological Area. American Antiquity 12:198-207.

Lee, Dayna B. (editor)

2001 Regional Variation and Protohistoric Identity: A Round Table Discussion from the $43^{\text {rd }}$ Caddo Conference. Caddoan Archeology 12(2/3):10-35.

Lemley, Harry J.

1936 Discoveries Indicating a Pre-Caddo Culture on Red River in Arkansas. Bulletin of the Texas Archeological and Paleontological Society 8:25-55.

Martin, Paul S., George T. Quimby, and Donald Collier

1947 Indians Before Columbus. The University of Chicago Press, Chicago.

Newell, H. Perry and Alex D. Krieger

1949 The George C. Davis Site, Cherokee County, Texas. Memoirs No. 5. Society for American Archaeology, Menasha, Wisconsin.

Perttula, Timothy K. (editor)

n.d. Proceedings of the Ninth Caddoan Conference, February 4 and 5, 1966, Natchitoches, Louisiana. Caddo Archeology Journal, in press.

Scholtz, James A.

1986 Preliminary Testing at the Powell Site, 3CL9: A Temple Mound Site in Clark County, Arkansas. The Arkansas Archeologist 23/24:11-42.

Suhm, Dee Ann, Alex D. Krieger, and Edward B. Jelks

1954 An Introductory Handbook of Texas Archeology. Bulletin of the Texas Archeological Society 25:1-562.

Swanton, John R.

1939 Final Report of the United States De Soto Expedition Commission. United States House of Representatives Document $71,76^{\text {th }}$ Congress, $1^{\text {st }}$ Session. Washington, D.C.

Thomas, Prentice M., L. Janice Campbell, and Steven R. Ahler

1980 The Hanna Site: An Alto Focus Village in Red River Parish. Louisiana Archaeology 5:1-381. Louisiana Archaeological Society, Lafayette.

Trubowitz, Neal L. and Marvin D. Jeter (editors)

1982 Arkansas Archeology in Review. Research Series 15. Arkansas Archeological Survey, Fayetteville.

Walker, Winslow M.

1935 A Caddo Burial Site at Natchitoches, Louisiana. Miscellaneous Collections 94(14). Smithsonian Institution, Washington, D.C.

Webb, Clarence H.

1940 House Types among the Caddo Indians. Bulletin of the Texas Archeological and Paleontological Society 12:4974.

1941 Pottery Types from the Belcher Mound Site. Bulletin of the Texas Archeological and Paleontological Society 13:88-116.

1945 A Second Historic Caddo Site at Natchitoches, Louisiana. Bulletin of the Texas Archeological Society 16:52-83.

1959 The Belcher Mound: A Stratified Caddoan Site in Caddo Parish, Louisiana. Memoirs No. 16. Society for American Archaeology, Salt Lake City.

1978 Changing Archeological Methods and Theory in the Trans-Mississippi South. In Texas History: Essays Honoring R. King Harris, edited by Kurt D. House, pp. 27-45. Reports of Investigations 3. Institute for the Study of Earth and Man. Southern Methodist University Press, Dallas.

Webb, Clarence H. and Ralph R. McKinney

1975 Mounds Plantation (16CD12), Caddo Parish, Louisiana. Louisiana Archaeology 2:39-127. 
Weinstein, Richard A., David B. Kelley, and Joe W. Saunders (editors)

2003 Louisiana and Arkansas Expeditions of Clarence Bloomfield Moore. University of Alabama Press, Tuscaloosa, and London.

Wood, W. Raymond

1963 Preliminary Report on the1962 Excavations at the Crenshaw Site - 3MI6. In Arkansas Archeology 1962, edited by Charles R. McGimsey III. Arkansas Archeological Society, Fayetteville.

1981 The Poole Site, 3GA3, with New Foreword and Summary by Ann M. Early. The Arkansas Archeologist 22:7-65.

Wood, W. Raymond and Rolland E. Pangborn

1968 The Eureka and Comstock Mounds, Southwestern Missouri. Plains Anthropologist 13 (39):1-17.

Woodbury, Richard B.

199360 Years of Southwestern Archaeology: A History of the Pecos Conference. University of New Mexico Press, Albuquerque. 


\section{Appendix I}

\section{MEETINGS BY STATE}

Arkansas: 12

Fayetteville: 1963, 1982, 1994

Arkadelphia: 1968, 1974, 1979, 1998, 2003

Magnolia: 1970, 2007

Texarkana: 1980

Little Rock: 1986

Louisiana: 13

Shreveport: 1950, 1957

Bossier City: 1987, 1992

Natchitoches: 1966, 1973, 1977, 1983, 1990, 1996, 2000, 2004, 2008

Oklahoma: 13

Norman, 1946, 1952, 1958, 1965, 1976, 1981, 1985, 1989, 1993, 1997, 2001, 2005

Tulsa: 1972

Texas: 12

Austin: 1962, 1971, 1995

Dallas: 1967,1988

College Station: 1975

Nacogdoches: 1978, 1984, 1991, 2002, 2006

Jefferson: 1999 


\section{Appendix II}

Museum of

The University

\section{THE UNIVERSITY OF OKLAHOMA NORMAN, OKLAHOMA}

October 16, 1946

Mr. Lynn E. Howard

Route \#2

Lexington, Oklahoma

Dear Lynn:

I am writing you at the suggestion of Dr. J. Willis Stovall regarding plans for the development of the Caddoan* Archaeological Ceramics Depository here at the University. But let me first say again how pleased and encouraged we were with the interest and productivity of the conference itself. The event certainly presages an active and profitable program of cooperation in working out the archaeological problems of the area of which Oklahoma is a part.

In presenting to you, by means of this letter, ideas as to how a ceramics depository might best serve workers in this area, it is realized that the practical functions which such a depository might be expected to serve have probably not been exhausted and also that some of the proposals infra may well be modified to the general advantage of all those interested in the project. In that light we solicit from you, as the first sign that you regard the general idea of the depository as of practical value and one which will work, any suggestions whatever as to how the proposed services may be made of greater value to participating workers in our field, or any other kinds of services not foreseen below.

It appears best to present these ideas first topically and without elaboration. The ideas have been adopted by the Museum and approved by the University of Oklahoma, subject to modification by suggestions from you as an interested worker in this field.

1. The Caddoan Archaeological Ceramics Depository should obtain and have on hand type collections of every possible component and/or focus in our area.

2. The CACD should make its information available to qualified workers by:

a) Verbal and written reports

b) Drawings and photographs of materials

c) Casts and molds of materials

3. The CACD should be a clearing house for the identification of materials which occur in our area or related areas.

4. The CACD should provide publication services.

In connection with the foregoing points, the following comments are offered: 
*(The term Caddoan is used tentatively and is subject to modification of the conference committee on that point.)

1. With a comprehensive and representative ceramic collection cross-catalogued according to typology and spatial and temporal location of finds, the depository should be in an excellent position to facilitate the work of identification and comparison of new materials and assignment of them to their proper connections. This would inestimably speed up the elementary job of relating any new site material to that already known. It would be necessary, in order to be able to do this, to have type materials from all workers in the area, either on a loan basis, or, when plentiful and the individual archaeologist willing, as a permanent deposit.

2. The work of relating new material to known material could be done by archaeologists' coming to Norman for personal examination of the references, but this would not by any means be necessary. Doubtful sherds could be sent in by mail, or workers could solicit information by writing inquiring of the occurrence of such-and-such materials in time and space. When need be, drawings and photographs, or even casts or molds, of materials could be furnished by the CACD.

3. With the CACD as a center or clearing house in the identification of materials of the area, there would be the maximum chance for proper identification of ceramic evidence. The opposite would be true without such a central clearing house.

4. The possibility of publication services of the CACD has already been considered favorably, Dr. Stovall informs me, by President Cross of the University. Funds should be available, it is understood, for publishing in substantial format something in the nature of "memoirs" of papers and conferences on our area. A less imposing type of publication, possibly an occasional mimeographed news letter, is suggested for notes and queries of lesser extent.

These are just the ideas which have so far been bought out in discussion here. More than likely, valuable additions and modifications could be made. For this, we are counting on your contribution and are anxious to hear from you, in any case, as to your reactions to the proposal. In the hope that we may have your comments as soon as possible, I am

\author{
Cordially Yours \\ (signed) Jim Watson \\ James B. Watson \\ Curator of Anthropology
}




\section{Appendix III}

From the Bulletin of the Texas Archeological Society, Vol. 31, published in 1961

Proceedings of the Fifth Conference on Caddoan Archeology

(pages 77-143), Edited by E. Mott Davis

\section{INTRODUCTION}

Nature of These Proceedings

Participants

Note on Symbols and Maps

DISTINGUISHING THE CADDOAN AREA

Introduction

The Geographical Area

The Formal Taxonomic Division

The Culture-historical Development

Merits of the Name "Caddoan"

ARCHAIC AND EARLY CERAMIC COMPLEXES ANCESTRAL, OR RELATED, TO THE GIBSON ASPECT

East Texas Archaic

Grove Focus

Fourche Maline

Sandy Pottery

Yarbrough, Sanders-like, and Related Sites

Early Crenshaw

Snipes Site, and Further Discussion of Plain Ware

CORRELATION OF LOWER RED RIVER AND CADDOAN SEQUENCES

Alba Points

THE HISTORICAL DEVELOPMENT FROM ARCHAIC TO GIBSON ASPECT

HISTORIC SITES IN THE CADDOAN AREA

GIBSON ASPECT CHRONOLOGY

REFERENCES CITED

\section{SAA Symposium (pages 3-76)}

\section{Relationship Between the Caddoan Area and Neighboring Areas}

The Caddoan Area: An Introduction to the Symposium, E. Mott Davis

Relationships Between the Caddoan and Central Louisiana Sequences, Clarence H. Webb

Discussion by Alex D. Krieger and James A. Ford

Relationships Between the Caddoan Area and the Mississippi Valley, by James B. Griffin Discussion by Phillip Phillips, Stephen Williams, and Alex D. Krieger 
Relationships between the Caddoan Area and the Plains, Robert E. Bell

Discussion by David A. Baerreis, Marvin F. Kivett, and Robert L. Stephenson

Relationships Between the Caddoan Area and Texas, by Edward B. Jelks Discussion by T. N. Campbell 